\title{
Influenza
}

vaccination

in children

with asthma

Herman Bueving 



\section{Influenza Vaccination in Children with Asthma}

Printed by Stadsdrukkerij Amsterdam NV

Cover design: Dirk van der Burgh, Stadsdrukkerij Amsterdam NV

Drawing: Denise Duijster

This research was financially supported by a grant from The Netherlands

Organisation for Health Research and Development (ZonMw)

Printing of this thesis was financially supported by the Department of General Practice, Erasmus MC-University Medical Center Rotterdam.

(C) HJ Bueving, 2005

ISBN 90744942 I 8

No part of this thesis may be reproduced, stored in a retrieval system or transmitted in any form or by any means, without permission of the author, or, when appropriate, of the publishers of publications. 



\title{
Influenza Vaccination in Children with Asthma
}

\author{
Griepvaccinatie bij kinderen met astma
}

\author{
Proefschrift \\ ter verkrijging van de graad van doctor aan \\ de Erasmus Universiteit Rotterdam \\ op gezag van de \\ rector magnificus
}

Prof.dr. S.W.J. Lamberts

en volgens besluit van het College voor Promoties.

De openbare verdediging zal plaatsvinden op

woensdag 6 april 2005 om 13.45 uur

door

Herman Johan Bueving

geboren te Groningen 


\section{Promotiecommissie}

Promotor: Prof.dr. S. Thomas

Overige leden: Prof.dr. J.C. de Jongste

Prof.dr. J.P. Mackenbach

Prof.dr. Th.J.M. Verheij

Copromotor: Dr. J.C. van der Wouden 
Opgedragen aan mijn geliefden 



\section{A-GRIEPVIRUS}

Waarom, gewaardeerde ridders

Van de aesculapenslang

Virus- en bacilaanbidders

Maakt U ons zo A-griep-bang?

Wij zijn dankbaar voor het vele

Dat U voor ons allen doet

En wij zien het A-griep-serum

Met verlangen tegemoet

Maar geleerde publicaties

En berichten enzovoorts

Zijn voor leken haast nóg erger

Dan de derde-daagse-koorts

Clinge Doorenbos 1957 


\section{Contents}

Chapter I Introduction I I

Chapter $2 \quad$ Incidence of influenza and associated illness in children 0-19 years: a systematic review $\quad$ I7

Chapter $3 \quad$ Does influenza vaccination exacerbate asthma? 35

Chapter 4A Influenza vaccination in children with asthma, randomised double-blind placebo-controlled trial $\quad 47$

Chapter 4B Influenza vaccination in children with asthma, randomised double-blind placebo-controlled trial, additional methods and results

Chapter $5 \quad$ Responsiveness, longitudinal and cross-sectional construct validity of the Pediatric Asthma Quality of Life Questionnaire in Dutch children with asthma

Chapter 6 Influenza vaccination in asthmatic children: effects on quality of life and symptoms $\quad 89$

$\begin{array}{ll}\text { Chapter } 7 & \text { General discussion } \\ & \text { I07 }\end{array}$

$\begin{array}{ll}\text { Summary } & \text { I23 }\end{array}$

Samenvatting I3 I

Publications and manuscripts related to this thesis $\quad$ I39

$\begin{array}{ll}\text { Persoonlijk dankwoord I4 I } & \text { I }\end{array}$ 
Chapter I

\author{
Introduction
}




\section{Introduction}

Infections of viral and bacterial origin are believed to cause exacerbations in patients with asthma. ${ }^{1}$ Most guidelines support the opinion that vaccination against influenza should be given to patients with asthma, including children. ${ }^{2,3}$ However, the proportion of children and adolescents with asthma that is vaccinated varies widely and is lower than that in the elderly. ${ }^{4}$ Fear of possible adverse reactions is one reason why patients are not given influenza vaccination as well as doubts about benefits and effectiveness of influenza vaccination amongst physicians and patients. ${ }^{5,6}$ Inhalation medication for relief and maintenance therapy has made it easier to control asthma and exacerbations can be prevented or suppressed. ${ }^{7}$ A systematic Cochrane review of randomised controlled trials concluded that there is at the moment not enough evidence to assess the benefits and risks of influenza vaccination for people with asthma. ${ }^{8}$ Thus, proof whether influenza vaccination exacerbates asthma as an adverse effect as well as direct proof of a protective effect on exacerbations in asthmatic patients is needed to resolve the doubts posed by this review.

Aim of this thesis is to provide evidence to either support or modify the policy of vaccinating asthmatic patients as is described in most western guidelines. ${ }^{2,3}$ I will focus on children, because in children asthma is the most important reason for influenza vaccination ${ }^{9}$ and asthma is the most frequent chronic disease in childhood.

In chapter 2 I review what is known about the incidence of influenza in children aged 0-19 years. I performed a systematic review of the literature on this subject, restricting myself to studies that focussed on laboratory confirmed influenza related illness, thus providing the best available evidence for the impact of influenza and influenza related illness in children with and without asthma.

Chapter 3 deals with the question whether influenza vaccination itself may exacerbate asthma, an often expressed fear. To investigate whether this fear is justified, I report on respiratory symptoms during the first week after vaccination of our placebo-controlled trial. I also present data on other possible side-effects during this period.

Chapter 4 describes the main results of a randomised placebo-controlled trial that was designed to measure the effectiveness of influenza vaccination in preventing 
asthma exacerbations in children with asthma. This is the first randomised placebocontrolled trial in children that took influenza confirmed asthma exacerbations as and endpoint. Almost 700 children were recruited in general practices in greater Rotterdam who participated during either season 1999-2000 or 2000-2001.

In order to measure quality of life in children with asthma we needed an appropriate questionnaire. Chapter 5 describes the cross-cultural validation of the Dutch Pediatric Asthma Quality of Life Questionnaire (PAQLQ). This questionnaire, originally designed in the English language by Juniper, ${ }^{10}$ is regarded an important asthma specific quality of life questionnaire in children ${ }^{11}$ and has also been validated in a Spanish ${ }^{12}$ and Swedish version. ${ }^{13}$ It was translated into Dutch by Grol et al under supervision of Juniper. ${ }^{14}$ Psychometric properties, responsiveness, and longitudinal and cross-sectional construct validity of the Dutch version of this 23-item PAQLQ were assessed.

Chapter 6 outlines the effect of influenza vaccination on various secondary outcome measures, i.e. quality of life as measured by PAQLQ, spirometry and respiratory symptomatology.

In chapter 7 the available knowledge on the burden of disease caused by influenza is debated, the absence of a universal definition of an "asthma exacerbation" is sketched and the results of our study given the current evidence on effectiveness of influenza vaccination in asthmatic children are discussed. Proposals are made to incorporate our findings in guidelines on influenza vaccination in asthmatic children. Finally, I offer some suggestions for future research into influenza, influenza related illness and influenza vaccination. 


\section{References}

1 Minor TE, Dick EC, DeMeo AN, et al. Viruses as precipitants of asthmatic attacks in children. JAMA 1974; 227: 292-8.

2 Nicholson KG, Snacken R, Palache AM. Influenza immunization policies in Europe and the United States. Vaccine 1995; 13: 365-9.

3 van Essen GA, Palache AM, Forleo E, Fedson DS. Influenza vaccination in 2000: recommendations and vaccine use in 50 developed and rapidly developing countries. Vaccine 2003; 21: 1780-5.

4 Kramarz P, DeStefano F, Gargiullo PM, et al. Influenza vaccination in children with asthma in health maintenance organizations. Vaccine Safety Datalink Team. Vaccine 2000; 18: 2288-94.

5 Fiebach NH, Viscoli CM. Patient acceptance of influenza vaccination. Am J Med 1991; 91: 393-400.

6 Nichol KL, Mac Donald R, Hauge M. Factors associated with influenza and pneumococcal vaccination behavior among high-risk adults. J Gen Intern Med 1996; 11: 673-7.

7 Williams SG, Schmidt DK, Redd SC, Storms W. Key clinical activities for quality asthma care. Recommendations of the National Asthma Education and Prevention Program. MMWR Recomm Rep 2003; 52: 1-8.

8 Cates CJ, Jefferson TO, Bara AI, Rowe BH. Vaccines for preventing influenza in people with asthma. Cochrane Database Syst Rev 2000; 7: CD000364.

9 Erhart LM, Rangel MC, Lu PJ, Singleton JA. Prevalence and characteristics of children at increased risk for complications from influenza, United States, 2000. J Pediatr 2004; 144: 191-5.

10 Juniper EF, Guyatt GH, Feeny DH, et al. Measuring quality of life in children with asthma. Qual Life Res 1996; 5: 35-46.

11 Osman L, Silverman M. Measuring quality of life for young children with asthma and their families. Eur Respir J Suppl 1996; 21: 35s-41s.

12 Tauler E, Vilagut G, Grau G, et al. The Spanish version of the paediatric asthma quality of life questionnaire (PAQLQ): metric characteristics and equivalence with the original version. Qual Life Res 2001; 10: 81-91.

13 Reichenberg K, Broberg AG. Quality of life in childhood asthma: use of the Paediatric Asthma Quality of Life Questionnaire in a Swedish sample of children 7 to 9 years old. Acta Paediatr 2000; 89: 989-95.

14 Juniper EF. Quality of life questionnaire for children and adolescents with asthma, Dutch version. McMaster University. Hamilton, Ontario, Canada, 1996. 


\section{Chapter 2}

Incidence of influenza and associated illness in children O-I9 years: a systematic review

(Submitted)

Bueving HJ, van der Wouden JC, Berger MY, Thomas S. 


\section{Incidence of influenza and associated illness in children O-I9 years: a systematic review}

\section{Abstract}

Information on the incidence and burden of a disease and its natural course is a prerequisite to reliably forecast the impact of preventive measures. Similarly, such data are needed to estimate the number of participants required for experimental trials. For influenza these figures are not easily available.

Therefore, we conducted a systematic review to estimate the incidence of influenza and concomitant morbidity and mortality in children 0 through 19 years $(0-19$ years). Medline was searched for observational studies and placebo or non-treated arms of experimental studies providing occurrence rates of laboratory-proven influenza illness.

From the 2758 titles identified, 356 full papers were reviewed based on the abstract or title; after searching their reference lists an additional 16 papers were found. Finally 28 studies met our inclusion criteria, reporting a varying seasonal incidence of influenza of up to $46 \%$. However, when analysing two long-term observational studies and averaging seasonal fluctuations, the overall incidence of influenza was found to range from 5 to $9.5 \%$ per year. Serious morbidity was seldom reported and no cases of mortality were found.

Given the average incidence, the self-limiting character of the disease, the mild associated morbidity and rare cases of mortality in children, one can question whether influenza in children in western countries at the population level is a major public health problem.

We conclude therefore that preventive strategies for children should be reconsidered. When studying influenza one should be led by the average incidence and include more influenza seasons.

\section{Introduction}

Influenza is a common respiratory tract infection in children ${ }^{1,2}$ and, according to the WHO, a yearly public health problem in children and in the community at large. ${ }^{3}$ Based on its occurrence and a rise in influenza-like illnesses, influenza 
centres worldwide provide information on its activity and presumed impact. ${ }^{4}$ Many viruses, however, can be responsible for influenza-like illness ${ }^{5-7}$ and the true incidence of influenza proper and its associated illness remains unclear. This implies that the advice of policymakers and public health authorities worldwide to vaccinate children with chronic health conditions (mainly asthma) ${ }^{8-10}$ and, more recently, healthy children under two years of age, ${ }^{11,12}$ is based on a subjective assessment of indirect evidence. For influenza proper, laboratory proof of its causal viruses should preferably coincide with symptomatic disease. ${ }^{13}$ However, in reports on the impact of influenza outbreaks, proxy measures are used, such as isolated serologic incidence rates, rates of influenza-like illness ${ }^{1,4,14-17}$ and complications. ${ }^{18-21}$ In these studies, however, hard confirmation of 'influenza illness' is lacking on the individual level and, moreover, reports on the disease burden of influenza (e.g. hospitalisations) are often not related to a well defined population at risk for influenza.

We became aware of this lack of hard data when we recently conducted a doubleblind placebo-controlled trial on the effectiveness of influenza vaccination in asthmatic children. ${ }^{22}$ When looking for data on incidence and disease burden related to influenza for our power calculations, we found out that these were scarce, showed a wide variation, and were of mixed quality.

With hindsight we concluded that before reasonable forecasts can be made about the need and cost effectiveness of preventive and curative measures for influenza in children, several questions about its natural course need to be addressed:

(1) What is the incidence of laboratory-proven influenza in children (aged 0-19 years)?

(2) What are the symptoms or illnesses that give rise to confirmatory laboratory tests?

(3) What is the related severity and duration of illness in fully confirmed cases?

(4) What is the nature and frequency of complications reported in these patients?

(5) What is the related health care use of these patients?

To answer the first two questions we performed a systematic review of communitybased epidemiological studies to investigate and assess the available data on the incidence of laboratory proven influenza in children 0-19 years. Additionally, we searched for data from non-treated or placebo treated arms of clinical trials on influenza vaccination or influenza treatment.

To answer the remaining questions the included studies were systematically reviewed for relevant data on severity, complications, and healthcare use. 


\section{Material and methods}

Studies were identified by a Medline database search from inception to October 2003. For the detection of studies on the epidemiology of influenza we used as search items "influenza/epidemiology OR influenza/mortality". For clinical trials studying treatment and prevention of influenza we adapted the search strategy as described by Dickersin et al. ${ }^{23}$ Using the 'Limits' option in Medline we limited searches to children (0 through 18 years), human subjects, and papers in English, German, French, and Dutch. Additional strategies for identifying studies included searching the reference lists of review articles and of included studies.

\section{Study selection}

Based on the search results, one of the authors (HJB) selected papers on the basis of title and abstracts. Abstracts were screened for clues of data of a prospective study on the incidence of influenza in children. If the screening was positive, or in case of doubt, full papers were obtained. Three of the authors (HJB, MYB, and JCvDW) checked these selected studies in couples of two reviewers.

Apart from studies including children recruited from the open community, we included studies in children residing in an institution, e.g. boarding schools and day care centres. In studies that also included larger age ranges, data concerning the age category 0-19 years were extracted whenever possible.

\section{Quality assessment}

We developed five quality criteria. (1) The study had to be prospective, that is either report on a longitudinal cohort or a dynamic population, or on placebo or non-treated arms of experimental studies. (2) The numerator of the study population should consist of cases of influenza illness proven by laboratory tests. (3) Laboratory methods should be performed in at least $75 \%$ of the participants with symptoms or illness. (3) The denominator should consist of a population of at least 30 children at risk for influenza followed over a specified time period. (4) The population at risk should not be pre-selected on the basis of symptoms of influenza-like illness, because this would invalidate the calculation of populationbased incidence rates. (5) Laboratory methods were culture, antigen detection or PCR from material taken from nose or throat, or serology from paired acute and convalescent blood samples. Studies were included if they fulfilled all five quality criteria. 
If in a reported period of illness tests were positive for influenza we attributed this illness to influenza infection.

The authors (HJB, MYB, and JCvDW) independently rated the methodological quality of all selected studies in couples of two reviewers. If necessary, reviewers discussed papers to reach consensus on inclusion. When consensus was not reached by a couple the opinion of the third reviewer was decisive.

\section{Data extraction}

Data extraction and synthesis were performed by one of the authors $(\mathrm{HJB})$ and verified by another author (JCvDW). If available we extracted information (using a structured form) on demographics, in- and exclusion criteria, a description of the study population, and occurrence of influenza.

For cohorts the incidence of influenza and illness is represented per influenza season or part of the season as reported, for dynamic populations (i.e. dropouts are replaced) we assumed the incidence per year to be equal to the incidence per influenza season.

\section{Results}

The search revealed 2758 studies after correction for duplicates; of these 356 were selected for reviewing. The references of these papers yielded 16 additional papers. Of these 372 papers meeting our inclusion criteria, the process of reviewing resulted in 28 studies.

Of the 342 rejected studies, 314 were excluded because influenza-like illness was not confirmed by laboratory testing or because the population at risk was preselected (e.g. consisting of only children with fever), or a combination of these items. Sixteen studies were excluded because laboratory tests were taken in less than $75 \%$ of the cases in the population at risk or the population consisted of less than 30 participants, 5 studies repeated findings from original and already included reports, and 7 were excluded for various other reasons.

There was a vast heterogeneity between studies regarding the span of time studied, laboratory methods used, criteria for performing laboratory tests, types of population and (knowledge of) vaccination status. Due to this heterogeneity we decided not to pool data between studies. To gain an overview, we did pool age categories within the studies if these data were collected over the same time period. When studies themselves pooled data for more influenza seasons, we provide these data. When studies report influenza incidence per influenza season 
or time period we present these data and also a weighted average in case of more than one period.

Data on the incidence of influenza in children aged 0-19 years are presented in Table 1; rates of influenza are given in percentages. As can be seen, the incidence found (in observational studies and in non-vaccinated participants of controlled clinical trials) varies widely from season to season, both for influenza A and B. Furthermore, a wide variety of index populations was studied. Some studies used an open setting, recruiting children from the general population or from different households, whereas other studies addressed more closed populations such as primary schools, day care centres, boarding schools or residential institutions. Research periods ranged from a few weeks to as long as 25 years.

The reported incidence of influenza in children varied in all age categories, and ranged from 0 to $46 \%$ [TABLE I]. However, in the two studies that reported the incidence of influenza over a prolonged time period, the average seasonal incidence was $4.6 \%$ in children aged $0-19$ years and $9.5 \%$ in children $<5$ years. ${ }^{16,24}$

In all studies the triggers to search for laboratory confirmation of influenza were local tract symptoms or systemic symptoms, mainly respiratory tract symptoms and fever. Two studies took laboratory samples when children where hospitalised for respiratory symptoms. ${ }^{25,26}$ Only a few of the studies provided extensive information on the course, duration and severity of disease or subsequent morbidity and complications. ${ }^{16,24,27}$ Symptoms triggering laboratory confirmation and symptoms described in the course of episodes of illness were usually characterised as mild. Mortality as an outcome of influenza illness was not found in any of the selected studies.

We provide a broad summary of illness and subsequent morbidity reported to be influenza related in the selected papers. We report both general remarks made by authors as well as remarks on an influenza specified laboratory-proven sample of the observed population. Because of our inclusion criterion of proven influenza, for some articles only a part of the population was included in this review. However, remarks of authors on disease were often only related to the broader definition used in their study. In case remarks relate to our more narrow selection, we also provide the number of children concerned.

Moffet et al. reported that the most prominent signs were fever and absence of localizing symptoms. Complications were uncommon and not severe or life threatening. Clinical recovery was rapid. In two out of 280 children there was radiological evidence of pneumonia but no child was severely ill, otitis media was diagnosed four times and sinusitis three times. ${ }^{28}$ Pereira et al. reported that in 262 children, 4 out of 6 influenza cases had only mild nasal symptoms and 


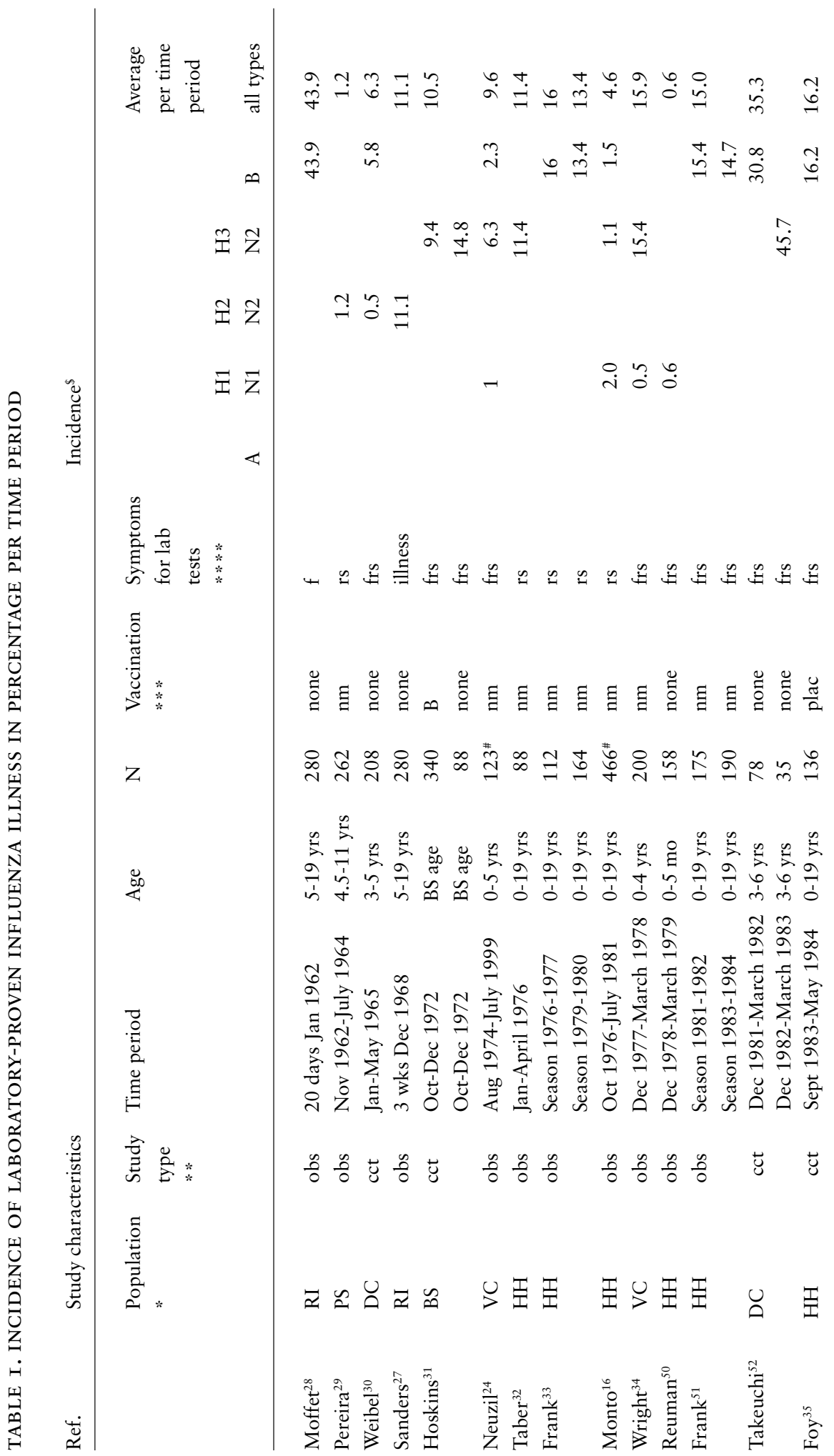




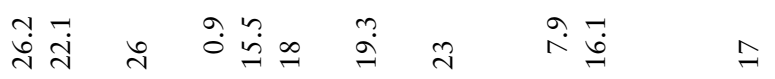

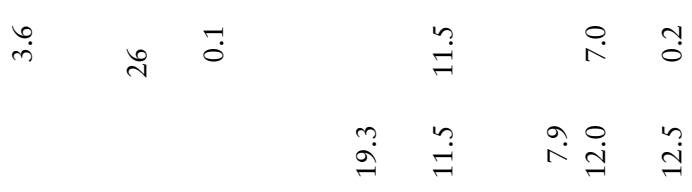

సి.

蚉毒

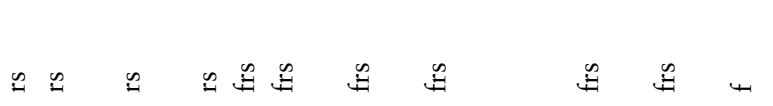

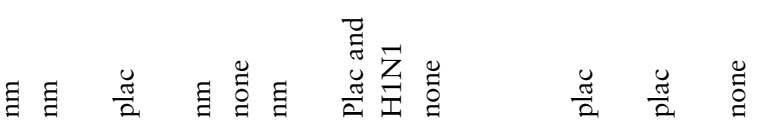

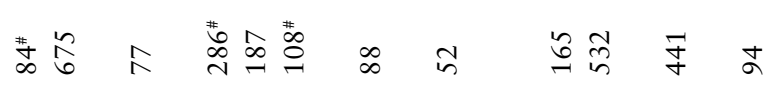

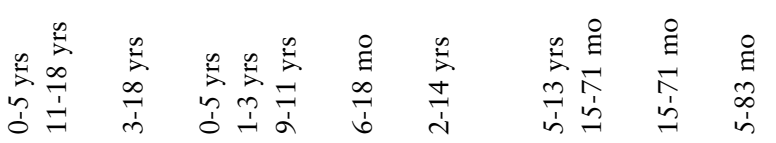

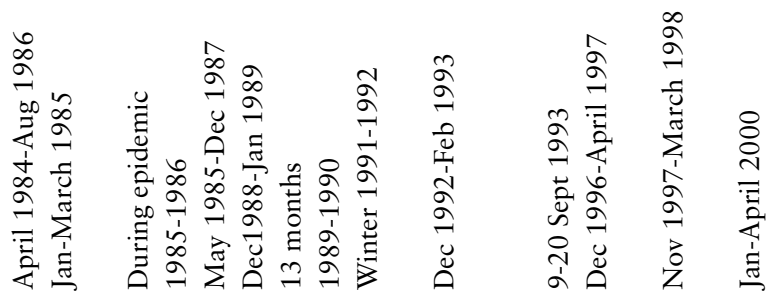

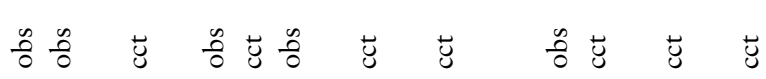

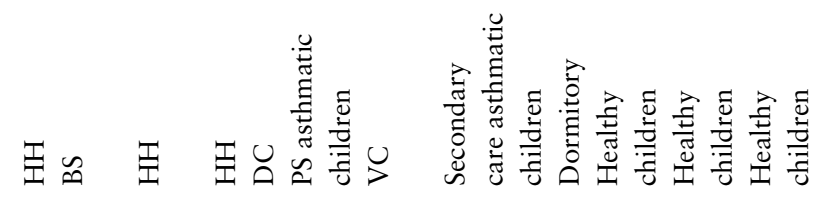

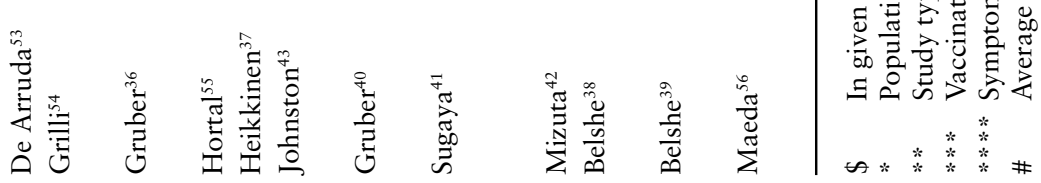


noted school absence of two days in only one case. ${ }^{29}$ Weibel et al. reported that 6 of 12 children with influenza B (from a total of 208), had severe respiratory illness, i.e. respiratory symptoms combined with fever above $102^{\circ} \mathrm{F} .{ }^{30}$ Sanders et al. found an average duration of three days of illness, and in $1.4 \%$ of 280 participants pneumonitis was documented by X-ray. ${ }^{27}$ Hoskins et al. reported usually mild illnesses. ${ }^{31}$ In a 25 -year study in children 0-5 years, Neuzil et al. reported that rates of acute otitis media and lower respiratory tract infections caused by influenza were higher in children under 2 years of age. ${ }^{24}$ Of an annual average of 123 children over 25 years, 8 were diagnosed as having croup, 7 pneumonia, 6 bronchiolitis, 3 tracheobronchitis and 2 epiglottitis. Seven children (all aged $<2$ years) were hospitalised with fever, a hospitalisation rate of 230 per 100,000; they were diagnosed as having meningitis (2), croup (2), pneumonia (1), periorbital cellulitis (1), and sepsis (1), and in three hospitalised children a bacterial super-infection was present. Duration of hospitalisation ranged from 1-10 days. Taber et al. described uncomplicated upper respiratory illness and three hospitalisations in younger children out of 88 children 0-19 years of age, a hospitalisation rate of $3.4 \% .^{32}$ Frank et al. reported that $77 \%$ of illnesses of children were febrile, influenza-like or lower respiratory illness, and one 18 monthold boy was hospitalised with a febrile seizure and evidence of pneumonia. ${ }^{33}$ Monto et al. observed (in 466 children and with an incidence of $4.6 \%$ over 5 years) for H3N2, H1N1 and B respectively, lower respiratory tract illness in 12, 13 and $15 \%$ of cases, fever in 84,64 and $71 \%$ of cases, physician consultation in 54,26 and $44 \%$ of cases, and a median duration of the illness of 12.7 days for influenza A and 10 days for influenza B. ${ }^{16}$ Wright et al. found "impressive illness", mainly fever and respiratory infections, caused by H3N2 and less illness by H1N1. ${ }^{34}$ Foy et al. reported "deceptively mild symptoms" which could easily be confused with common colds. ${ }^{35}$ Gruber et al. found an incidence of $26 \%$ in 77 children and recorded in $35 \%$ illness (otitis media and tracheobronchitis) and in $31 \%$ fever in reported cases of influenza. ${ }^{36}$ Heikkinen et al. found that 29 $(67 \%)$ out of 187 children with influenza A suffered from otitis media whereas Belshe et al. reported percentages for otitis media of 46 and 30 in about $16 \%$ of 973 children infected. ${ }^{37-39}$ Gruber et al. reported fever and otitis media in $14 \%$ of 19 affected children out of a total of $88 .{ }^{40}$ Sugaya et al. reported that $60 \%$ of 12 affected children (out of a total of 52) had febrile influenza illness and found three hospitalisations for pneumonia with influenza $\mathrm{B}$, a hospitalisation rate of almost $6 \%{ }^{41}$ Mizuta et al. described fever, headache, sore throat, cough and nasal discharge in 13 cases out of 165 children. $^{42}$

We detected two studies that provided prospective data on the incidence of 
influenza if hospitalisation for respiratory symptoms due to influenza was regarded and, because this trigger for taking laboratory tests is different from the other studies, we report these separately [TABLE 2]. Additionally, we present data on hospitalisation that were reported in a long term study by Neuzil et al. ${ }^{24}$ and that could be calculated from two small studies by Taber et al. ${ }^{32}$ and Sugaya et al. ${ }^{41}$ Incidence rates of hospitalisation due to influenza range from 8 to 5769 admissions per 100,000 children at risk per year. Caul et al. reported complementary data on morbidity, i.e. convulsions with or without respiratory illness were in $36 \%$ the reason for admission in the presence of influenza, especially in those aged 1-2 years. Furthermore, upper respiratory infections were in $43 \%$ of influenza cases, croup in $7 \%$, bronchitis in $19 \%$, bronchiolitis in $11 \%$, pneumonia in $11 \%$ and convulsions alone in $15 \%$ the reason for hospital admission. ${ }^{25}$

TABLE 2. INCIDENCE OF HOSPITAL ADMISSION FOR INFLUENZA-PROVEN RESPIRATORY SYMPTOMS. FIGURES PER IOO,OOO CHILDREN AT RISK PER TIME PERIOD

\begin{tabular}{|c|c|c|c|c|c|c|}
\hline \multirow[t]{2}{*}{ Ref. } & \multicolumn{4}{|c|}{ Population characteristics } & \multicolumn{2}{|c|}{ Incidence ${ }^{\$}$} \\
\hline & Population & Time periods & Age & Vaccination* & $\mathrm{A}$ & B \\
\hline \multirow[t]{10}{*}{$\operatorname{Martin}^{26}$} & adherent & epidemic periods & $<16$ yrs & $\mathrm{nm}$ & 32 & \\
\hline & based on & 1971-1972 & & & & \\
\hline & census & epidemic periods & & & 25 & \\
\hline & approximately & $1972-1973$ & & & & \\
\hline & 150,000 & epidemic periods & & & 8 & \\
\hline & & $1973-1974$ & & & & \\
\hline & & epidemic periods & & & 28 & \\
\hline & & 1974-1975 & & & & \\
\hline & & epidemic periods & & & 52 & \\
\hline & & $1975-1976$ & & & & \\
\hline \multirow[t]{2}{*}{ Caull $^{25}$} & adherent ${ }^{\#}$ & Nov 1973- & $0-4$ yrs & $\mathrm{nm}$ & 59 & 7 \\
\hline & 59311 & March 1975 & & & & \\
\hline Taber $^{32}$ & 88 & Jan-April 1976 & $0-19$ yrs & $\mathrm{nm}$ & 3409 & \\
\hline Sugaya ${ }^{41}$ & 52 & Dec 1992-Feb 1993 & $2-14$ yrs & none & 5769 & \\
\hline Neuzil $^{24}$ & $123^{\#}$ & Aug 1974-July 1999 & $0-5$ yrs & $\mathrm{nm}$ & 230 & \\
\hline
\end{tabular}

\$ In given time period, in case the time period encompasses more than one year the incidence is calculated and averaged per year

* $\mathrm{nm}=$ not mentioned \# Average annual number in surveillance 


\section{Discussion}

We found a wide variation in incidence data on influenza and influenza-proven illnesses in children aged 0-19 years. Of course year, place and composition of the population all may have an important impact on the incidence of influenza and related illness. Furthermore, a considerable number of observational studies were motivated by an outburst of influenza in more or less closed populations and, therefore, provide a one-sided picture of the overall incidence. It is likely that years with no or little influenza activity were underrepresented. In addition, clinical trials are not designed to assess the incidence of overall illness for influenza, but will for obvious reasons focus on a certain degree of clinical illness by using a threshold before taking samples. Most of these biases will overestimate the true incidence of influenza.

With all these restrictions incidence of laboratory-proven influenza, coinciding with illness, ranged from 0 to $46 \%$ in the studies we included. When we consider the highest incidence rates for influenza and associated illness, health care utilisation probably would be considerable. In that case, the prevention of influenza could be extremely cost effective leading to considerable health benefits. However, a high incidence is mostly found in more closed populations and at outbursts of influenza, and this may distort the picture. As can be seen in studies in the open population, the incidence of influenza (averaged over several years of follow-up), is much lower, i.e. respectively $4.6 \%$ (0-19 years) and $9.5 \%$ (0-5 years). ${ }^{16,24}$ The yearly average incidence of influenza and its related illness in these dynamic populations is probably the best estimate that policymakers, health authorities and researchers can rely on.

The impact of preventive measures for influenza will be less favourable if we also consider the reported subsequent morbidity and complications next to the symptom-based incidence of influenza. In most studies included, reported influenza-related illness was low, the morbidity pattern of influenza was mild, the number of hospital admissions was small, and no mortality due to influenza was reported.

Children younger than two years of age may need special attention, because we found that a relatively high incidence of influenza and most complications occurred in this age group. ${ }^{24}$ Reasons for protecting the younger age groups and chronic disease categories in children mainly come from large retrospective studies on hospitalisation, and the use of medication or consultation for respiratory tract infections during influenza seasons. ${ }^{18,19}$ Neuzil et al. estimated (over a 19 -year period) an excess hospitalisation due to influenza-related disease of 
40 to 1040 per 100,000 children (aged 0-15 years) at risk per year, declining with age. ${ }^{19}$ Izurieta et al. estimated over a 5-year study period a similar decline in excess hospitalisation of 1.5 to 19 per 100,000 children (aged 0-18 years) per year. ${ }^{18}$ Prospective figures as mentioned here in the census-based and long-term studies of between 29 and 230 hospitalisations for influenza per season or year per 100,000 children 0-16 years of age at risk ${ }^{24-26}$ are in line with the findings of Izurieta et al. and the lower boundaries of rates of hospitalisations as found by Neuzil et al. The much higher incidences of hospitalisation found by Taber et al. and Sugaya et al. will probably be less accurate due to the small numbers of participants and a limited time window, i.e. an outburst of influenza. ${ }^{32,41}$ Influenza in children is a self-limiting disease. Hospital admissions due to influenza are rare. Based on the figures presented, $\mathrm{H} 3 \mathrm{~N} 2$ and $\mathrm{B}$ variants are found more frequently than H1N1. Illness due to H1N1 seems to be mild or absent.

Although our search of the literature has revealed specifically those studies that focus totally or in part on influenza it is, however, possible that studies on other topics (e.g. other viruses), containing information on the incidence of influenza and illness were missed. The incidence of infection with less severe symptoms or sub-clinical influenza can of course be higher. However, a mild course of the disease makes treatment less relevant.

As most studies found were performed in developed countries with a welldeveloped health care system, we cannot extrapolate our findings to the less developed countries.

Our findings on the varying incidence of influenza and the self-limiting character of most diseases caused by influenza in children do not support strategies proposing to vaccinate all healthy children year after year. The two studies in asthmatic children revealed no serious complications in this disease category. ${ }^{41,43}$ In closed populations incidence may be high but severe complications are, again, uncommon.

Over the years, doubts have been expressed about the protective effect of influenza vaccination in children for the prevention of clinical illness. ${ }^{22,44-47}$ Moreover, the ever-changing antigenic appearance of the influenza virus and logistic problems surrounding the vaccine production make it difficult to produce a matching vaccine in adequate time.

New antiviral treatments (e.g. the new neuraminidase inhibitors), may play a role in the prevention and treatment in non-pandemic influenza seasons in children. However, although clinical effectiveness has been established in healthy children, no efficacy was found in children with asthma, ${ }^{48}$ being the most important chronic condition for which vaccination is advised. ${ }^{49}$ 
None of our findings strongly supports the necessity of extending preventive and curative health care in influenza seasons. A preparedness plan for children with influenza has to consider the unpredictable incidence of influenza and illness as a result of the infection, which over the years on average is low, and the self-limiting character of the disease in children. Therefore, it will be difficult to attain health benefits and cost effectiveness over the years.

When researching the incidence of influenza and its related illness, and determining the effect of preventive and curative measures, studies should cover several seasons. Also, when calculating the power for clinical trials one should take account of the reported overall averages of influenza incidence as found in longterm observational studies, instead of isolated incidence rates.

\section{References}

1. Monto AS, Kioumehr F. The Tecumseh Study of Respiratory Illness. IX. Occurence of influenza in the community, 1966-1971. Am J Epidemiol 1975; 102: 553-563.

2. Freymuth F, Vabret A, Gouarin S, et al. Epidemiology of respiratory virus infections. Allerg Immunol (Paris) 2001; 33: 66-69.

3. Influenza. WHO. Revised March 2003. Available at: http://www.who.int/mediacentre/ factsheets/2003/fs211/en/.

4. Update: influenza activity-United States and worldwide, 2003-04 season, and composition of the 2004-05 influenza vaccine. MMWR Morb Mortal Wkly Rep 2004; 53: 547-552.

5. Wallace LA, Collins TC, Douglas JD, et al. Virological surveillance of influenza-like illness in the community using PCR and serology. J Clin Virol 2004; 31: 40-45.

6. Iwane MK, Edwards KM, Szilagyi PG, et al. Population-based surveillance for hospitalizations associated with respiratory syncytial virus, influenza virus, and parainfluenza viruses among young children. Pediatrics 2004; 113: 1758-1764.

7. Freymuth F, Vabret A, Gouarin S, et al. Epidemiology and diagnosis of respiratory syncitial virus in adults. Rev Mal Respir 2004; 21: 35-42.

8. Nicholson KG, Snacken R, Palache AM. Influenza immunization policies in Europe and the United States. Vaccine 1995; 13: 365-369.

9. van Essen GA, Palache AM, Forleo E, Fedson DS. Influenza vaccination in 2000: recommendations and vaccine use in 50 developed and rapidly developing countries. Vaccine 2003; 21: 1780-1785.

10. Eisner MD. Asthma and influenza vaccination. Chest 2003; 124: 775-777. 
11. Principi N, Esposito S. Are we ready for universal influenza vaccination in paediatrics? Lancet Infect Dis 2004; 4: 75-83.

12. Harper SA, Fukuda K, Uyeki TM, et al. Prevention and control of influenza: recommendations of the Advisory Committee on Immunization Practices (ACIP). MMWR Recomm Rep 2004; 53: 1-40.

13. Monto AS. Use of selective viral cultures to adjust nonvirologic endpoints in studies of influenza vaccine efficacy. Am J Epidemiol 2003; 158: 312-315.

14. Foy HM, Cooney MK, Allan I. Longitudinal studies of types A and B influenza among Seattle schoolchildren and families, 1968-74. J Infect Dis 1976; 134: 362-369.

15. Fox JP, Hall CE, Cooney MK, Foy HM. Influenzavirus infections in Seattle families, 1975-1979. I. Study design, methods and the occurrence of infections by time and age. Am J Epidemiol 1982; 116: 212-227.

16. Monto AS, Koopman JS, Longini IM, Jr. Tecumseh study of illness. XIII. Influenza infection and disease, 1976-1981. Am J Epidemiol 1985; 121: 811-822.

17. Tokugawa K, Ueda K, Sakoh M, et al. Seroepidemiologic study on influenza A (H1N1) virus infection among school children after an "antigenic shift" from A (H3N2) to a (H1N1) in Kukuoka of southern Japan in 1978. Pediatr Infect Dis J 1987; 6: 761-762.

18. Izurieta HS, Thompson WW, Kramarz P, et al. Influenza and the rates of hospitalization for respiratory disease among infants and young children. N Engl J Med 2000; 342: 232-239.

19. Neuzil KM, Mellen BG, Wright PF, et al. The effect of influenza on hospitalizations, outpatient visits, and courses of antibiotics in children. N Engl J Med 2000; 342: 225 231.

20. Meier CR, Napalkov PN, Wegmuller Y, et al. Population-based study on incidence, risk factors, clinical complications and drug utilisation associated with influenza in the United Kingdom. Eur J Clin Microbiol Infect Dis 2000; 19: 834-842.

21. Kim MR, Lee HR, Lee GM. Epidemiology of acute viral respiratory tract infections in Korean children. J Infect 2000; 41: 152-158.

22. Bueving HJ, Bernsen RM, De Jongste JC, et al. Influenza vaccination in children with asthma: randomized double-blind placebo-controlled trial. Am J Respir Crit Care Med 2004; 169: 488-493.

23. Dickersin K, Berlin JA. Meta-analysis: state-of-the-science. Epidemiol Rev 1992; 14: 154-176.

24. Neuzil KM, Zhu Y, Griffin MR, et al. Burden of interpandemic influenza in children younger than 5 years: a 25 -year prospective study. J Infect Dis 2002; 185: 147-152. 
25. Caul EO, Waller DK, Clarke SK. A comparison of influenza and respiratory syncytial virus infections among infants admitted to hospital with acute respiratory infections. J Hyg (Lond) 1976; 77: 383-392.

26. Martin AJ, Gardner PS, McQuillin J. Epidemiology of respiratory viral infection among paediatric inpatients over a six-year period in north-east England. Lancet 1978; 2: 1035-1038.

27. Sanders DY, Carroll NB, Jeffreys LU, Vick SS. Outbreak of influenza A2 (Hong Kong strain) in a children's home. South Med J 1970; 63: 414-416.

28. Moffet HL, Cramblett HG, Middleton GK, Jr., et al. Outbreak of influenza B in a children's home. JAMA 1962; 182: 834-838.

29. Pereira MS, Andrews BE, Gardner SD. A study on the virus aetiology of mild respiratory infections in the primary school child. J Hyg (Lond) 1967; 65: 475-483.

30. Weibel RE, Stokes J, Jr., Leagus MB, et al. Respiratory virus vaccines. V. Field evaluation for efficacy of heptavalent vaccine. Am Rev Respir Dis 1966; 94: 362-379.

31. Hoskins TW, Davies JR, Allchin A, et al. Controlled trial of inactivated influenza vaccine containing the a-Hong Kong strain during an outbreak of influenza due to the a-England-42-72 strain. Lancet 1973; 2: 116-120.

32. Taber LH, Paredes A, Glezen WP, Couch RB. Infection with influenza A/Victoria virus in Houston families, 1976. J Hyg (Lond) 1981; 86: 303-313.

33. Frank AL, Taber LH, Glezen WP, et al. Influenza B virus infections in the community and the family. The epidemics of 1976-1977 and 1979-1980 in Houston, Texas. Am J Epidemiol 1983; 118: 313-325.

34. Wright PF, Thompson J, Karzon DT. Differing virulence of H1N1 and H3N2 influenza strains. Am J Epidemiol 1980; 112: 814-819.

35. Foy HM, Cooney MK, Allan ID, Albrecht JK. Influenza B in households: virus shedding without symptoms or antibody response. Am J Epidemiol 1987; 126: 506-515.

36. Gruber WC, Taber LH, Glezen WP, et al. Live attenuated and inactivated influenza vaccine in school-age children. Am J Dis Child 1990; 144: 595-600.

37. Heikkinen T, Ruuskanen $\mathrm{O}$, Waris $\mathrm{M}$, et al. Influenza vaccination in the prevention of acute otitis media in children. Am J Dis Child 1991; 145: 445-448.

38. Belshe RB, Mendelman PM, Treanor J, et al. The efficacy of live attenuated, coldadapted, trivalent, intranasal influenzavirus vaccine in children. N Engl J Med 1998; 338: 1405-1412.

39. Belshe RB, Gruber WC. Prevention of otitis media in children with live attenuated influenza vaccine given intranasally. Pediatr Infect Dis J 2000; 19: S66-71. 
40. Gruber WC, Belshe RB, King JC, et al. Evaluation of live attenuated influenza vaccines in children 6-18 months of age: safety, immunogenicity, and efficacy. National Institute of Allergy and Infectious Diseases, Vaccine and Treatment Evaluation Program and the Wyeth-Ayerst ca Influenza Vaccine Investigators Group. J Infect Dis 1996; 173: 1313-1319.

41. Sugaya N, Nerome K, Ishida M, et al. Efficacy of inactivated vaccine in preventing antigenically drifted influenza type A and well-matched type B. JAMA 1994; 272 : 1122-1126.

42. Mizuta K, Oshitani H, Mpabalwani EM, et al. An outbreak of influenza A/H3N2 in a Zambian school dormitory. East Afr Med J 1995; 72: 189-190.

43. Johnston SL, Pattemore PK, Sanderson G, et al. Community study of role of viral infections in exacerbations of asthma in 9-11 year old children. BMJ 1995; 310: 1225-1229.

44. Hoberman A, Greenberg DP, Paradise JL, et al. Effectiveness of inactivated influenza vaccine in preventing acute otitis media in young children: a randomized controlled trial. JAMA 2003; 290: 1608-1616.

45. Cates CJ, Jefferson TO, Bara AI, Rowe BH. Vaccines for preventing influenza in people with asthma. The Cochrane Database of Systematic Reviews 2004, Issue 4. Art. No.: CD000364.pub000362. DOI: 000310.001002/14651858.CD14000364. pub14651852.

46. Bueving $\mathrm{HJ}$, van der Wouden JC, Raat $\mathrm{H}$, et al. Influenza vaccination in asthmatic children: effects on quality of life and symptoms. Eur Respir J 2004; 24: 925-931.

47. Christy C, Aligne CA, Auinger P, et al. Effectiveness of influenza vaccine for the prevention of asthma exacerbations. Arch Dis Child 2004; 89: 734-735.

48. Matheson NJ, Symmonds-Abrahams M, Sheikh A, et al. Neuraminidase inhibitors for preventing and treating influenza in children. The Cochrane Database of Systematic Reviews 2003, Issue 3. Art. No.: CD002744. DOI: 002710.001002/14651858. CD14002744.

49. Erhart LM, Rangel MC, Lu PJ, Singleton JA. Prevalence and characteristics of children at increased risk for complications from influenza, United States, 2000. J Pediatr 2004; 144: 191-195.

50. Reuman PD, Ayoub EM, Small PA. Effect of passive maternal antibody on influenza illness in children: a prospective study of influenza A in mother-infant pairs. Pediatr Infect Dis J 1987; 6: 398-403.

51. Frank AL, Taber LH, Porter CM. Influenza B virus reinfection. Am J Epidemiol 1987; 125: 576-586. 
52. Takeuchi Y. Epidemiological and clinical features of influenza and respiratory syncytial virus infections among children in Japan. Acta Paediatr Jpn 1988; 30: 231-239.

53. de Arruda E, Hayden FG, McAuliffe JF, et al. Acute respiratory viral infections in ambulatory children of urban northeast Brazil. J Infect Dis 1991; 164: 252-258.

54. Grilli EA, Anderson MJ, Hoskins TW. Concurrent outbreaks of influenza and parvovirus B19 in a boys' boarding school. Epidemiol Infect 1989; 103: 359-369.

55. Hortal M, Russi JC, Arbiza JR, et al. Identification of viruses in a study of acute respiratory tract infection in children from Uruguay. Rev Infect Dis 1990; 12 Suppl 8: S995-997.

56. Maeda T, Shintani Y, Miyamoto H, et al. Prophylactic effect of inactivated influenza vaccine on young children. Pediatr Int 2002; 44: 43-46. 


\section{Chapter 3}

Does influenza vaccination exacerbate asthma?

Vaccine 2004; 23: 91-6.

Bueving HJ, Bernsen RMD, de Jongste JC, van Suijlekom-Smit LWA, Rimmelzwaan GF, Osterhaus ADME, Rutten-van Mölken MPMH, Thomas S, van der Wouden JC. 


\title{
3. Does influenza vaccination exacerbate asthma?
}

\begin{abstract}
The risks of influenza vaccination in asthmatic children are still being discussed. Especially the risk that influenza vaccination may exacerbate asthma is an issue in this debate.

We conducted a randomised double-blind placebo-controlled trial in 696 children 6-18 years of age with asthma recruited in general practice during two influenza seasons, 1999-2000 and 2000-2001. Children participated for only one season. During the first week after vaccination, participants recorded local, influenza like and asthma symptoms as well as use of medication, health care use and absenteeism.

Except for cough during the day in the first season, favouring placebo, there were no differences indicating that vaccination exacerbates asthma.

Influenza vaccination does not seem to exacerbate asthma.
\end{abstract}

\section{Introduction}

Because viral infections, including influenza, cause exacerbations in children with asthma, ${ }^{1,2}$ vaccination of such children is recommended in most of Europe and North America. ${ }^{3}$ Fear of possible adverse reactions is one reason why patients are not given influenza vaccination ${ }^{4,5}$ and in asthmatic children vaccination rates have been reported to be very low. ${ }^{6,7}$ Although influenza vaccination has few adverse reactions it is uncertain whether it exacerbates asthma. ${ }^{8-13}$ We therefore performed a double blind placebo-controlled trial in asthmatic children and examined if influenza vaccination exacerbates asthma. We will report on asthma symptoms and other adverse reactions, i.e. local and influenza like symptoms in the first week after vaccination. We will also give an account of use of medication, health care use and absenteeism.

\section{Methods}

We conducted a randomised double blind placebo-controlled trial in children with asthma recruited in general practice during two seasons, 1999-2000 and 2000- 
2001. We recently reported the effects of vaccination on asthma exacerbations related to influenza infections. ${ }^{14}$

In this part of the study, we aim to answer the question if there is a difference in reported adverse reactions, especially asthma symptoms, between vaccine and placebo recipients.

Eligible were children aged 6-18 years who had used specific asthma medication: maintenance medication (inhaled corticosteroids, cromoglycate) or more than 52 doses of relief medication ( $\beta$-2-agonists, anticholinergics) for asthma the year previous to inclusion. Exclusion criteria were other chronic diseases, allergy to chicken protein and insufficient understanding of the Dutch language. In both seasons, research nurses vaccinated all participants between 25 October and 24 November with either inactivated influenza vaccine or placebo. Every child participated for only one season. The vaccine composition for 1999-2000 was a combination of A/Sydney/5/97 (H3N2)-like, A/Beijing/262/95 (H1N1)-like and B/Beijing/184/93-like strains and for 2000-2001 A/Moscow/10/99 (H3N2)-like, A/New Caledonia/20/99 (H1N1)-like and B/Beijing/184/93-like strains as advised by the World Health Organisation. The placebo consisted of a buffered phosphate solution with the same $\mathrm{pH}$ value and was similar in appearance to the inactivated influenza vaccine. The manufacturer (Solvay Pharmaceutical Products, Weesp, the Netherlands) stored the vaccines after production at 2 to $8{ }^{\circ} \mathrm{C}$. Vaccines were transported to and stored under optimal conditions at the central pharmacy of the University Hospital Rotterdam until shortly before vaccination.

Participants recorded symptoms of influenza like illness and asthma in a diary. Symptoms scored in the diaries during the first seven days after vaccination were considered to be adverse reactions of the vaccination. Additionally, we asked during these seven days for red or painful arm, use of medication, contact with a physician and absence from school or work for participants and their parents. If present, respiratory tract symptoms were scored from 1 (mild) to 3 (severe) and summated. Serious adverse reactions that were reported after the first week were scrutinised to assess their causal relation with the vaccination.

In the analysis, the frequencies of symptoms reported in the group of children that received vaccine were compared to those receiving placebo, in order to assess the magnitude of the proportion of symptoms that could be ascribed to the vaccine. Differences were tested by Pearson $\chi^{2}$ tests with continuity correction with one-sided p-values of 0.05 in case of categorical variables and with ANOVA for numerical data. 


\section{Results}

TABLE I. BASELINE CHARACTERISTICS OF THE STUDY POPULATION (N=696)

values are percentages unless otherwise stated

vaccine placebo

age in years, mean (SD)

$\mathrm{n}=347 \quad \mathrm{n}=349$

child born in the Netherlands

$10.5(3.2) \quad 10.6(3.3)$

female sex

97.7

98.9

48.1

43.6

age of onset of asthma in years, mean (SD)

$3.5(3.8)$

$3.3(3.4)$

asthma complaints more than once a week in previous 12 months

15.6

18.6

only maintenance medication in previous 12 months

29.1

24.4

relief and maintenance medication in previous 12 months

59.9

64.8

$\mathrm{FEV}_{1}-\%$ predicted, mean (SD)

$89.5(16.1) \quad 88.9(16.0)$

ever treated by asthma specialist

40.7

46.6

still treated by asthma specialist

25.9

27.1

ever hospitalised for asthma

16.2

17.0

vaccinated previous season for influenza

51.4

53.0

ever vaccinated for influenza

53.6

56.7

if vaccinated before, number of seasons, mean (SD)

$2.9(1.9)$

$2.8(1.8)$

history of allergy

73.5

66.1

proven allergy for pollen, house dust mite or pets

47.3

44.7

history of eczema

50.6

48.4

seasonal influence on asthma

74.4

77.0

family history of asthma

78.7

77.1

exposure to cigarette smoke at home

30.3

33.2

current smoker

pets at home

58.2

59.6

After inclusion and informed consent 696 children were randomised (first season 296, second season 400). The groups were similar for baseline characteristics [TABLE I]. In the first season 148 children were vaccinated with influenza vaccine and 148 with placebo vaccine. In the second season 199 children were vaccinated with influenza vaccine and 201 with placebo. For adverse reactions, the proportion of missing data per item varied from $0 \%$ to $6 \%$. Local symptoms (erythema and painful or stiff arm) were often reported, especially the first four days after vaccination [TABLE 2]. The proportion of children reporting these two local symptoms the first seven days after vaccination was about three times as high 


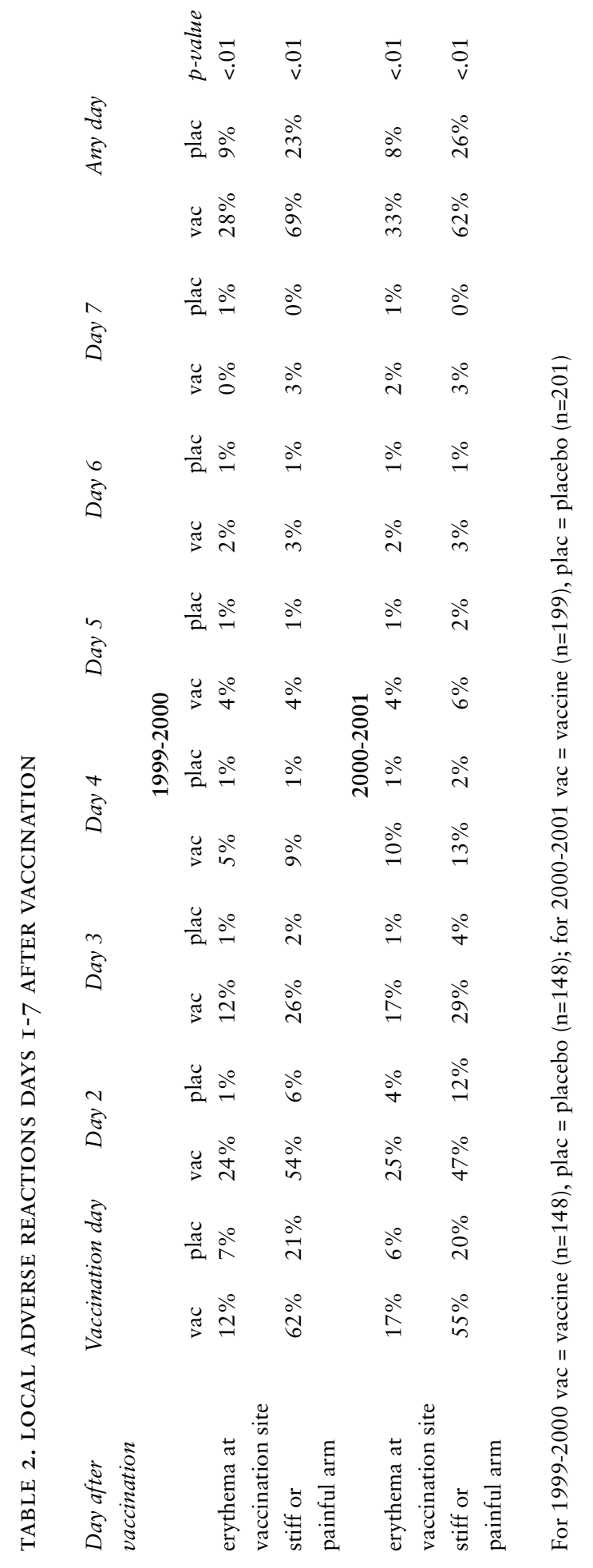


$\frac{2}{2}$

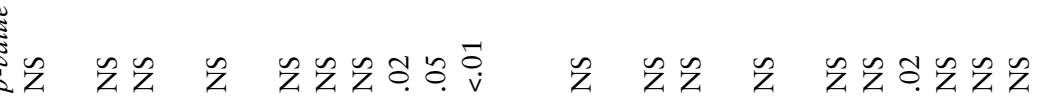

ङ

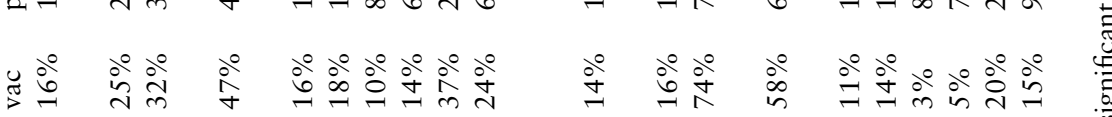

thi

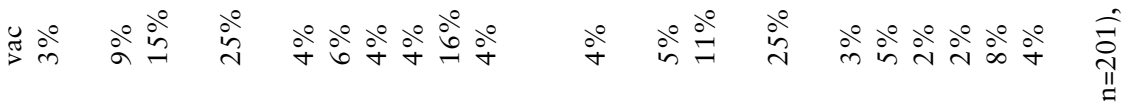

ㄱ $\quad$ i

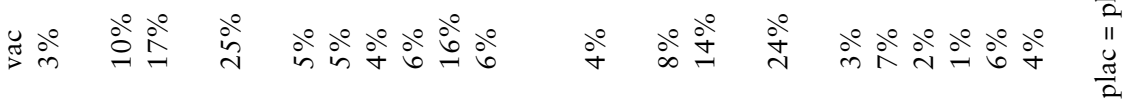

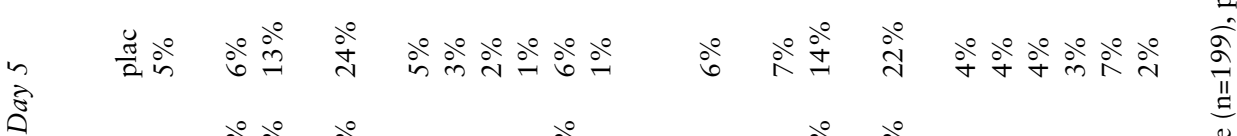

ஓ्্்

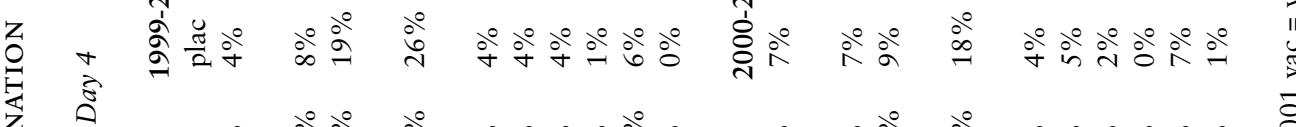

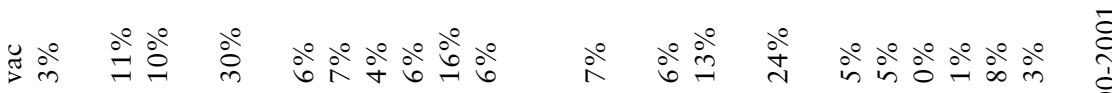

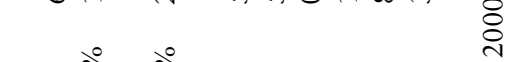

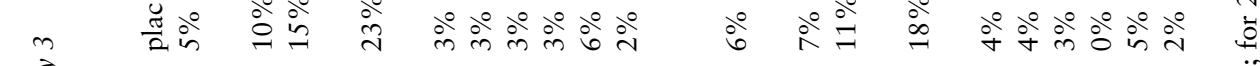

i

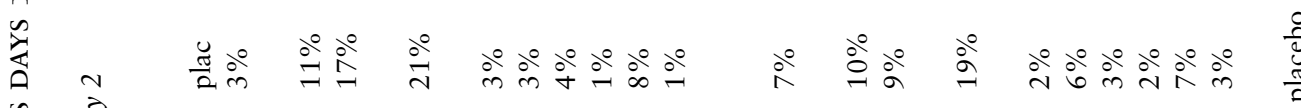

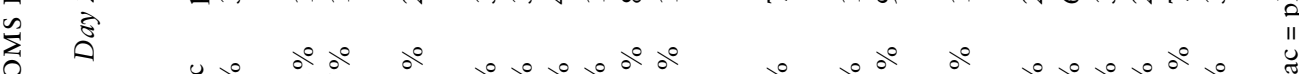

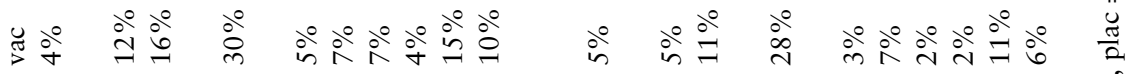

हे $\quad$ ¿

:

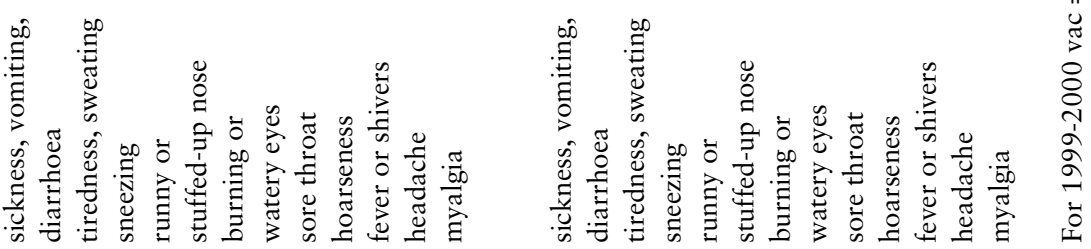




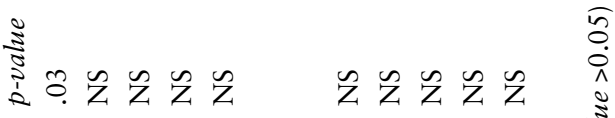

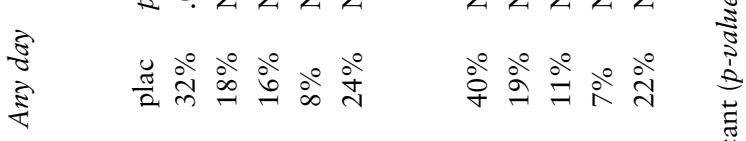

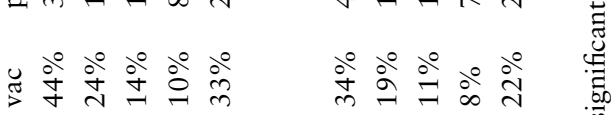

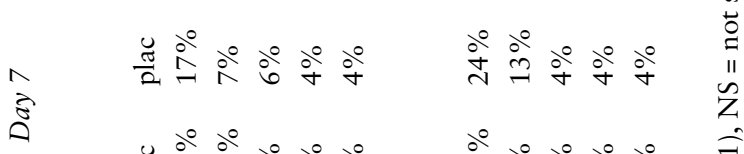

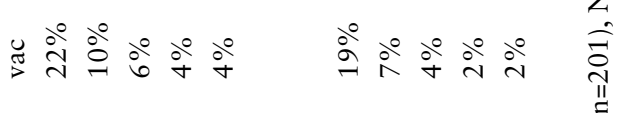

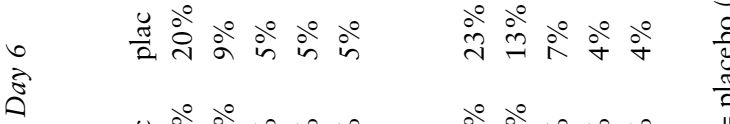

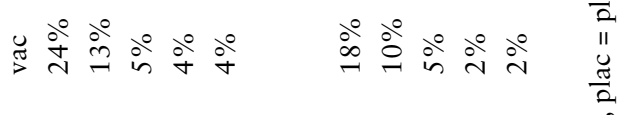

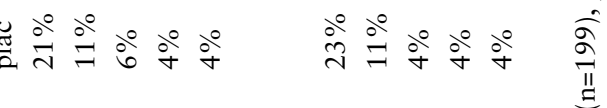
空

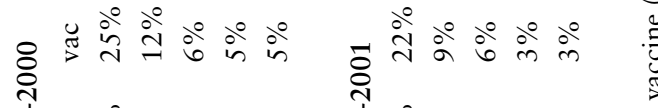
+

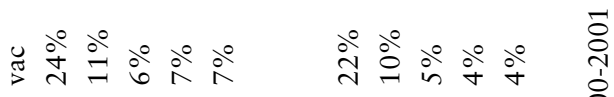
บํํㅇำ

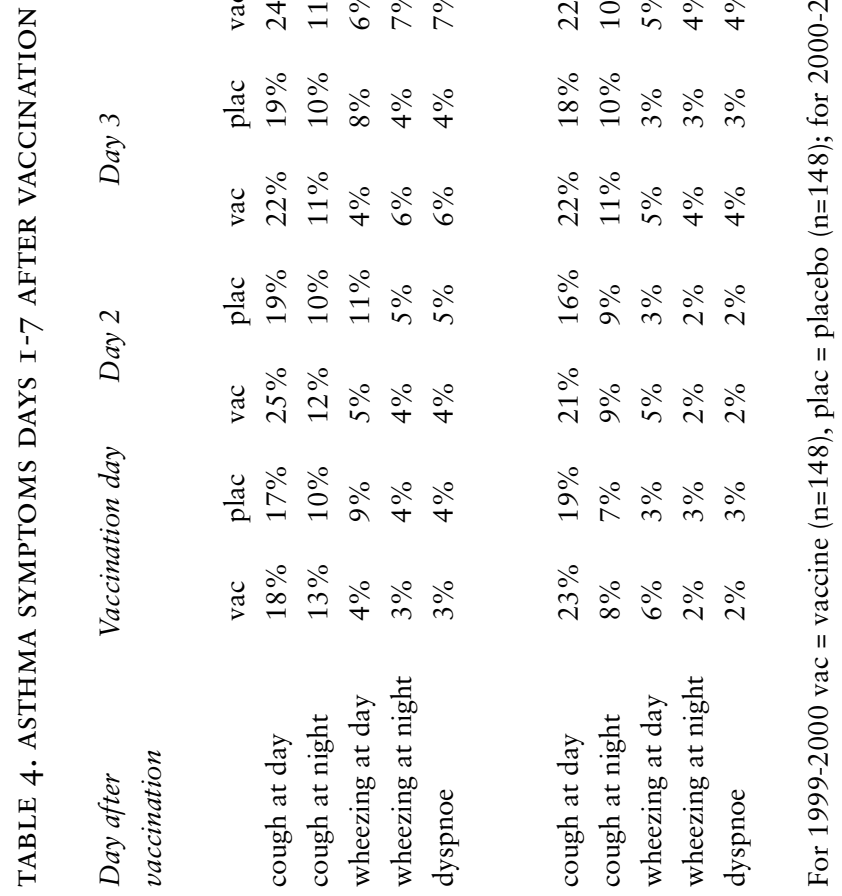


in the vaccine group as in the placebo group, with absolute differences of up to $23 \%$ for erythema and up to $48 \%$ for stiffness or pain during the first days after vaccination. For influenza like symptoms, no consistent pattern was found [TABLE 3]. Fever $(8 \%)$, headache $(10 \%)$ and myalgia $(18 \%)$ were reported significantly more often in the vaccine group than in the placebo group during the first season, especially at days 4-6 after vaccination. During the second season, hoarseness showed a difference of $5 \%$ favouring the placebo group. For asthma symptoms, only the first season showed a difference of $12 \%$ ( $44 \%$ vs. $32 \%$ ) in cough during daytime favouring placebo [TABLE 4]. The severity of asthma symptoms, as measured by symptom scores, showed no difference between the groups.

The use of medication for airway symptoms, physician consultations, school absenteeism, and work absenteeism as well as the number of children that needed a child-minder as a consequence of the adverse reactions did not differ [TABLE 5]. The mean number of doses of relief medication taken in the first week was 4.5 per child in both groups.

In December 1999 a serious illness (mastocytosis) was reported by the parents of one of the participating children. Upon careful consideration of onset and course of illness, it was decided that a causal relationship with the study medication was highly unlikely. Afterwards, we established that this child had received placebo.

TABLE 5. MEDICATION USE, CONSULTATION AND ABSENTEEISM, DAYS I-7 AFTER VACCINATION

1999-2000

$\begin{array}{ll}\text { vaccine } & \text { placebo } \\ (\mathrm{n}=148) & (\mathrm{n}=148)\end{array}$

2000-2001

p-value vaccine placebo p-value $(\mathrm{n}=199) \quad(\mathrm{n}=201)$

medication for

airway symptoms

medication use total

consultation of doctor

school absenteeism

work absenteeism

childminder needed

$\begin{array}{rrr}67 \% & 69 \% & \text { NS } \\ 70 \% & 71 \% & \text { NS } \\ 0 \% & 1 \% & \text { NS } \\ 6 \% & 10 \% & \text { NS } \\ 0 \% & 0 \% & \text { NS } \\ 0 \% & 0 \% & \text { NS }\end{array}$

$\begin{array}{rrr}68 \% & 62 \% & \text { NS } \\ 71 \% & 65 \% & \text { NS } \\ 2 \% & 1 \% & \text { NS } \\ 5 \% & 3 \% & \text { NS } \\ 1 \% & 1 \% & \text { NS } \\ 1 \% & 0 \% & \text { NS }\end{array}$

$\mathrm{NS}=$ not significant $(p$-value $>0.05)$ 


\section{Discussion}

The most important finding in this trial is that, with exception of cough during daytime in the first season, no differences were found for the frequency and severity of asthma symptoms as an adverse reaction to vaccination. There were no differences in the use of relief medication. Fever, headache and myalgia showed small though significant differences during the first season, as did hoarseness during the second season. These differences may be an expression of the difference in strains used in the vaccine during the two seasons or can be a result of a difference in populations between the two influenza seasons. As reported in previous studies, vaccine recipients reported redness and stiffness of the arm much more often than placebo recipients. ${ }^{12,15}$

Our findings do not support previous conclusions in a systematic Cochrane review, which especially stated the risk of influenza vaccination to exacerbate asthma. ${ }^{13}$

A recent placebo-controlled crossover study of the American Lung Association Clinical Centers did not find any adverse reactions on asthma-related outcomes. ${ }^{12}$ Other studies had prospective or retrospective designs without placebo, which are prone to various sources of bias and make comparison difficult. ${ }^{11,16,17}$ All previously mentioned studies recruited patients in secondary or tertiary care centres, whereas we recruited in general practice. A limitation of our study is that in comparison with other studies in asthmatic patients our study population may consist of less severe asthmatics, so our findings can not be extrapolated to all children in secondary or tertiary care. However, we only included children with moderate or severe asthma, that, according to national and international guidelines, ${ }^{3,18}$ should all be vaccinated.

We found that influenza vaccination of children with asthma in general practice had no severe local or general adverse reactions in asthmatic children. No extra precautions have to be taken when vaccinating these children. If influenza vaccination for children with asthma is advised, strategies have to be developed and used to convince patients, parents and doctors of those facts.

In conclusion, apart from mild adverse reactions, fear that influenza vaccination exacerbates asthma seems to be no valid reason to refrain from immunising asthmatic children with inactivated influenza vaccine. 


\section{References}

1 Minor TE, Dick EC, DeMeo AN, et al. Viruses as precipitants of asthmatic attacks in children. JAMA 1974; 227: 292-8.

2 Johnston SL, Pattemore PK, Sanderson G, et al. Community study of role of viral infections in exacerbations of asthma in 9-11 year old children. BMJ 1995; 310: 1225-9.

3 Nicholson KG, Snacken R, Palache AM, Fedson DS. Influenza immunization policies in Europe and the United States. Vaccine 1995; 13: 365-9.

4 Fiebach NH, Viscoli CM. Patient acceptance of influenza vaccination. Am J Med 1991; 91: 393-400.

5 Nichol KL, Mac Donald R, Hauge M. Factors associated with influenza and pneumococcal vaccination behavior among high-risk adults. J Gen Intern Med 1996; 11: 673-7.

6 Szilagyi PG, Rodewald LE. Missed opportunities for influenza vaccination among children with asthma. Pediatr Infect Dis J 1992; 11: 705-8.

7 Kramarz P, DeStefano F, Gargiullo PM, Storms W. Influenza vaccination in children with asthma in health maintenance organizations. Vaccine Safety Datalink Team. Vaccine 2000; 18: 2288-94.

8 McIntosh K, Foy H, Modlin JF, et al. Multicenter two-dose trials of bivalent influenza A vaccines in asthmatic children aged six to 18 years. J Infect Dis 1977; 136: S645-7.

9 Park CL, Frank A. Does influenza vaccination exacerbate asthma? Drug Saf 1998; 19: 83-8.

10 Nicholson KG, Nguyen-Van-Tam JS, Ahmed AH, et al. Randomised placebocontrolled crossover trial on effect of inactivated influenza vaccine on pulmonary function in asthma. Lancet 1998; 351: 326-31.

11 Kramarz P, DeStefano F, Gargiullo PM, et al. Does influenza vaccination exacerbate asthma? Analysis of a large cohort of children with asthma. Vaccine Safety Datalink Team. Arch Fam Med 2000; 9: 617-23.

12 The American Lung Association Asthma Clinical Centers. The safety of inactivated influenza vaccine in adults and children with asthma. N Engl J Med 2001; 345: 152936.

13 Cates CJ, Jefferson TO, Bara AI, Rowe BH. Vaccines for preventing influenza in people with asthma (Cochrane Review). Oxford: Update Software, 2002.

14 Bueving HJ, Bernsen RM, de Jongste JC, et al. Influenza vaccination in children with asthma: randomized double-blind placebo-controlled trial. Am J Respir Crit Care Med 2004; 169: 488-93. 
15 Edwards KM, Dupont WD, Westrich MK, et al. A randomized controlled trial of coldadapted and inactivated vaccines for the prevention of influenza A disease. J Infect Dis 1994; 169: 68-76.

16 Hilman BC, Jamison RM, Kirkpatrick CJ. Reactivity and antibody response to vaccination with bivalent influenza A/Victoria/75-A/New Jersey/76 vaccines in children with chronic pulmonary diseases. J Infect Dis 1977; 136: S638-44.

17 Gruber WC, Taber LH, Glezen WP, et al. Live attenuated and inactivated influenza vaccine in school-age children. Am J Dis Child 1990; 144: 595-600.

18 G.A. van Essen, Sorgedrager YCG, G.W. Salemink, et al. NHG-Standaard Influenza en influenzavaccinatie [NHG-standard influenza and influenza vaccination], Huisarts Wet. 1996; 39: 564. 


\section{Chapter $4 a$}

Influenza vaccination in children with asthma: randomised double-blind placebo-controlled trial

American Journal of Respiratory and Critical Care Medicine 2004; 169: 488-93.

Bueving HJ, Bernsen RMD, de Jongste JC, van Suijlekom-Smit LWA, Rimmelzwaan GF, Osterhaus ADME, Rutten-van Mölken MPMH, Thomas S, van der Wouden JC. 


\section{4a. Influenza vaccination in children with asthma: randomised double-blind placebo-controlled trial}

\section{Abstract}

There is little evidence that influenza vaccination reduces asthma exacerbations. We determined whether influenza vaccination is more effective than placebo in asthmatic children 6-18 years of age.

We performed a randomised double-blind placebo-controlled trial. Parenteral vaccination with inactivated influenza vaccine or placebo took place between 25 October and 24 November and children were followed until April 1st of the next year. Airway symptoms were reported in a diary. When symptom scores reached a predefined level, a pharyngeal swab was taken. Primary outcome was the number of asthma exacerbations associated with virologically proven influenza infection.

Three hundred forty-nine children were assigned placebo and 347 were assigned vaccine. Pharyngeal swabs positive for influenza were related to 42 asthma exacerbations, 24 in the vaccine group and 18 in the placebo group, a difference of $33 \%$ favouring placebo (31\% after adjustment for confounders, $95 \% \mathrm{CI}-34 \%$ to $161 \%)$. Influenza-related asthma exacerbations were of similar severity in both groups, they lasted 3.1 days shorter in the vaccine group (95\% CI -6.2 to 0.002 days, $\mathrm{p}=0.06$ ).

We conclude that influenza vaccination did not result in a significant reduction of the number, severity or duration of asthma exacerbations caused by influenza. Additional studies are warranted to justify routine influenza vaccination of asthmatic children.

\section{Introduction}

Infections of viral origin, including influenza, cause exacerbations in patients with asthma. ${ }^{1,2}$ Most guidelines support the opinion that influenza vaccination should be given to patients with asthma, including children. ${ }^{3}$

Over the years the necessity of vaccinating patients with asthma has been discussed. ${ }^{4-6}$ A Cochrane systematic review on influenza vaccination in people 
with asthma concludes that, because of the lack of randomised trials, the evidence to assess the benefits and risks of influenza vaccination is insufficient. ${ }^{7}$ Inhalation medication for relief and maintenance therapy has made it easier to control asthma and exacerbations can be prevented or suppressed, so patients can lead a normal life.

The proportion of children with asthma that is vaccinated varies widely and is lower than in the elderly. ${ }^{8}$ This is partly due to doubts amongst patients and doctors about the benefit of the vaccination and lack of evidence for the protective effect of influenza vaccination against asthma exacerbations. ${ }^{9,10}$

An answer to the question whether influenza vaccination can prevent exacerbations in asthmatic children is necessary to either validate or modify current guidelines and may enhance evidence-based practice.

We conducted a study to investigate whether influenza vaccination in asthmatic children prevents asthma exacerbations provoked by influenza infection. Some of the results of this study have been previously published in the form of abstracts. ${ }^{11-13}$

\section{Methods}

\section{Participants}

We performed a randomised double-blind placebo-controlled parallel trial in children 6-18 years of age with asthma, recruited through family physicians in the city of Rotterdam and its surroundings, during the winter seasons of 19992000 and 2000-2001. Patients could only participate for one season. Exclusion criteria were other chronic diseases, allergy to chicken protein and insufficient understanding of the Dutch language. See chapter $4 \mathrm{~b}$ (additional methods and results) for further details. We informed parents and children orally and in written text about the purpose and contents of the study and obtained informed consent for those willing to participate. The Medical Ethical Committee of Erasmus MC - University Medical Center Rotterdam approved the study.

\section{Interventions}

In both seasons, research nurses vaccinated all participants between 25 October and 24 November with either inactivated influenza vaccine or placebo. Vaccine details are provided in chapter $4 \mathrm{~b}$ (additional methods and results). 


\section{Objectives}

We aimed to answer the question whether influenza vaccination is more effective than placebo in preventing asthma exacerbations caused by influenza infections among asthmatic children 6-18 years of age. We tested the null hypothesis that placebo is as effective as influenza vaccination in preventing asthma exacerbations caused by influenza infections.

\section{Outcomes}

Primary outcome was the number of asthma exacerbations associated with virologically proven influenza infection. Secondary outcomes were amongst others the duration and severity of these asthma exacerbations, adverse effects of the vaccination including airway symptoms, the number, duration and severity of all asthma exacerbations, and of influenza-related and all upper respiratory tract (URT) episodes. Additional outcomes are listed in chapter 4b (additional methods and results).

\section{Respiratory tract symptoms and episodes}

Following the method described by Johnston et al, ${ }^{2}$ participants were asked to fill in a diary, starting the day after vaccination, and daily score symptoms of upper and lower respiratory tract, use of medication, physician visits and other use of medical facilities. An episode of either URT or LRT symptoms was defined as two or more days with symptom scores above the median for that child preceded by at least one day at or below the median and followed by at least two days at or below the median (cf. Johnston et al.) ${ }^{2}$ [FIGURE I]. An asthma exacerbation was defined as an episode of LRT symptoms.

Further details are provided in chapter $4 \mathrm{~b}$ (additional methods and results).

\section{Virological and serological assessments}

Throat swab material was analysed by culture, immunofluorescence and RT-PCR. A full description of the methods used is provided in chapter $4 \mathrm{~b}$ (additional methods).

We took blood samples (4 cc) before vaccination (sample 1), 14-21 days afterwards (sample 2) and at the end of the season, around the 1st of April (sample 3). The presence of influenza virus specific antibodies was performed by 


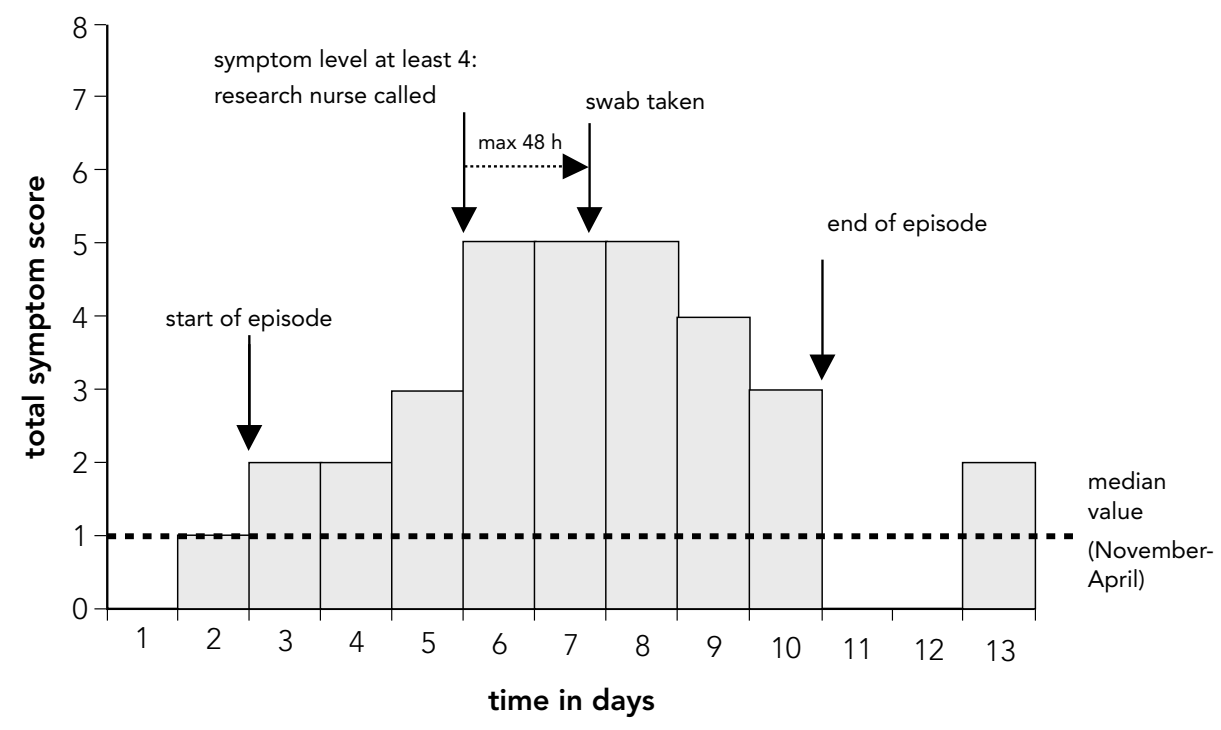

a hemagglutination inhibition assay; details are given in chapter $4 \mathrm{~b}$ (additional methods and results).

A four-fold increase in post-season serum antibody titre (comparing sample 2 and 3) was considered an indication for an influenza virus infection.

\section{Sample size}

We wanted to be able to detect a $50 \%$ reduction in the number of asthma exacerbations caused by influenza with $\alpha=0.05$ and $80 \%$ power. Assuming a $30 \%$ influenza incidence in the placebo group and $50 \%$ of these infected children reacting with an exacerbation, we aimed at a total number of 600 children, i.e. 300 children per season.

Chapter $4 \mathrm{~b}$ (additional methods and results) provides additional information on sample size calculation, randomisation procedure, blinding, assessment of adverse effects and statistical analyses.

\section{Results}

Altogether 144 family practices (200 physicians) participated. They selected 3220 children and informed these children and their parents by letter about the 


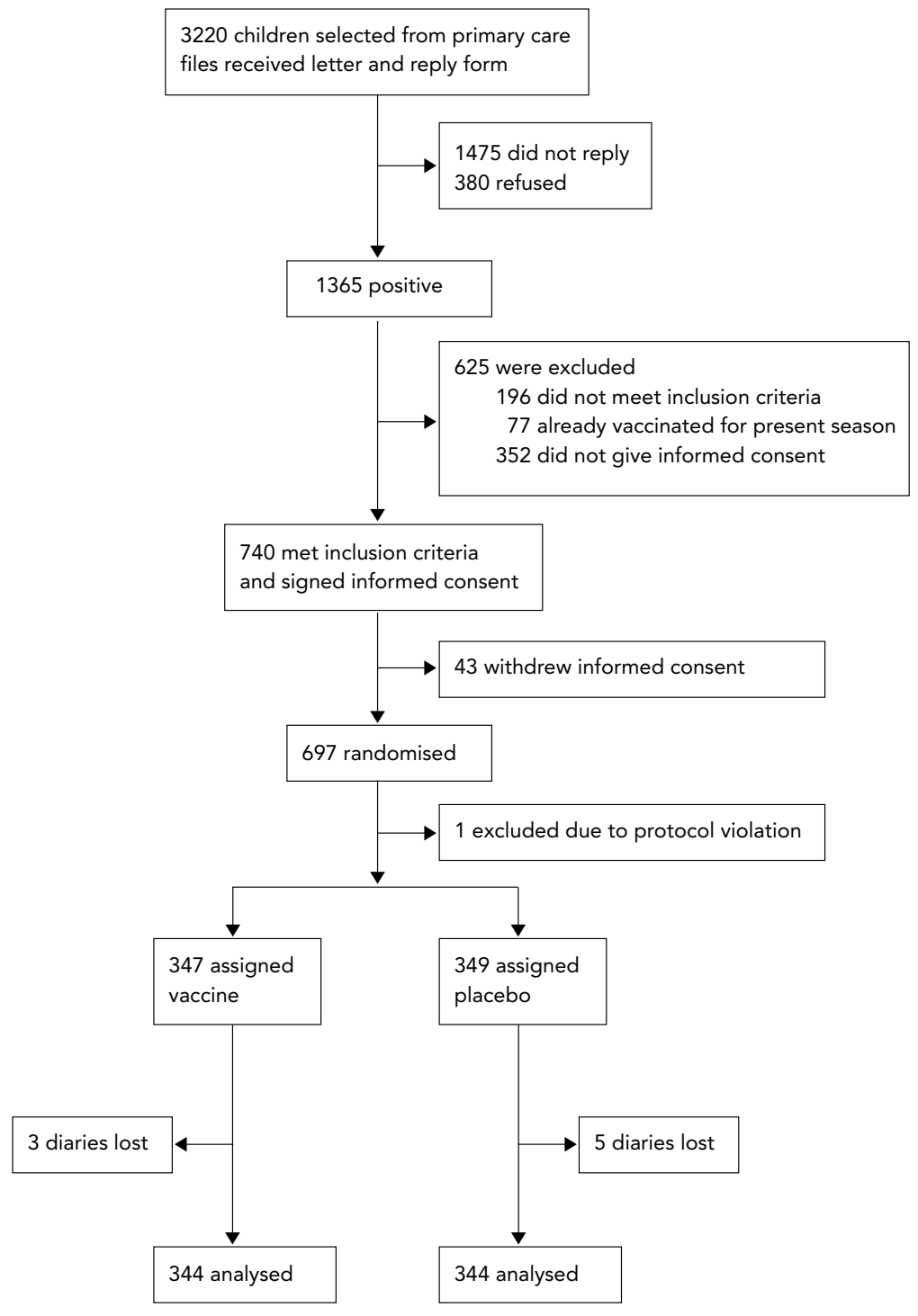

objectives of our study. In total, 1365 children were willing to participate. After inclusion and informed consent 697 children were randomised (first season 297, second season 400) [FIGURE 2]. One participant, after having received the study intervention, was mistakenly vaccinated by her family doctor as well and excluded because of protocol violation. Of the remaining participants, 347 were vaccinated with influenza vaccine and 349 with placebo. In each group 
344 participants provided diary data for primary outcomes. The proportion of diary days for which no data were available was $4.7 \%$. Because the number of missing diaries was very small, we decided not to impute data but to exclude these children from the analysis for these outcomes.

\section{Baseline characteristics}

The groups were similar for baseline characteristics except for history of allergy [TABLE I]. Almost $90 \%$ of children had used maintenance medication for asthma during the previous 12 months; $55 \%$ of the children had been vaccinated against influenza before.

TABLE I. BASELINE CHARACTERISTICS OF THE STUDY POPULATION (N=696)

Values are percentages unless otherwise stated

age in years, mean $(\mathrm{SD})$

female sex

age of onset of asthma in years, mean (SD)

asthma complaints more than once a week previous 12 months

only maintenance medication in previous 12 months

relief and maintenance medication in previous 12 months

$\mathrm{FEV}_{1}-\%$ predicted, mean (SD)

ever treated by asthma specialist

still treated by asthma specialist

ever hospitalised for asthma

vaccinated previous season for influenza

ever vaccinated for influenza

if vaccinated before, number of seasons, mean (SD)

history of allergy

proven allergy for pollen, house dust mite, or pets

history of eczema

seasonal influence on asthma

family history of asthma

exposure to cigarette smoke at home

current smoker

pets at home

child born in the Netherlands vaccine Placebo

$$
\mathrm{n}=347 \quad \mathrm{n}=349
$$

$10.5(3.2) \quad 10.6(3.3)$

$48.1 \quad 43.6$

$3.5(3.8) \quad 3.3(3.4)$

$15.6 \quad 18.6$

$29.1 \quad 24.4$

$59.9 \quad 64.8$

$89.5(16.1) \quad 88.9(16.0)$

$40.7 \quad 46.6$

$25.9 \quad 27.1$

$16.2 \quad 17.0$

$51.4 \quad 53.0$

$53.6 \quad 56.7$

$2.9(1.9) \quad 2.8(1.8)$

$73.5 \quad 66.1$

$47.3 \quad 44.7$

$50.6 \quad 48.4$

$74.4 \quad 77.0$

$78.7 \quad 77.1$

$30.3 \quad 33.2$

$2.6 \quad 2.6$

$58.2 \quad 59.6$

$97.7 \quad 98.9$ 


\section{Influenza activity}

In our study, in the season 1999-2000 the first influenza positive swab was taken on 17 December 1999 and the last one on 20 January 2000. All were influenza A virus and the four cultures from these swabs all yielded H3N2. Dutch primary care sentinel stations detected influenza A H3N2 from week 45 (8 November) in 1999 until week 8 (21 February) in 2000. ${ }^{14}$

In the season 2000-2001 in our study the first influenza A virus was detected on 21 November 2000 and the last on 23 March 2001. All cultures yielded H1N1. Three influenza B positive swabs were obtained between 7 and 13 March 2001. This season sentinel stations reported influenza A H1N1 from week 50 (11 December) in 2000 until week 8 (19 February) in 2001. Influenza B was spotted in week 8 (19 February 2001-26 February 2001)..$^{15}$

TABLE 2. INFLUENZA VIRUSES DETECTED BY EITHER CULTURE, IMMUNOFLUORESCENCE OR PCR IN PHARYNGEAL SWABS COLLECTED UPON CALLS FOR AIRWAY SYMPTOMS

\begin{tabular}{lrrrrr} 
absolute numbers & \multicolumn{2}{c}{$1999-2000$} & & $2000-2001$ & total \\
& vaccine & placebo & vaccine & placebo & \\
total number of calls & 112 & 111 & 139 & 124 & 486 \\
influenza A & $2(2)$ & $6(7)$ & $20(21)$ & $13(9)$ & $41(39)$ \\
influenza B & 0 & 0 & $1(1)$ & $2(2)$ & $3(3)$
\end{tabular}

In parentheses: number of asthma exacerbations linked to positive swab results

\section{Primary outcome}

We received 486 calls (from 347 children) to report a symptom score of 4 points or more, 251 from the vaccine group and 235 from the placebo group. In 44 of the throat swabs collected upon these calls, influenza virus was detected [TABLE 2], of which 38 (21 in vaccine group, 17 in placebo group) could be linked to one or more asthma exacerbations, our primary outcome measure. This resulted in 42 influenza-related exacerbations. Of these, 24 were found in the group that received influenza vaccination and 18 in the placebo group, a difference of $33 \%$ (crude) or $31 \%$ after adjustment (95\% CI ranging from 34\% reduction to $161 \%$ increase) [TABLE 3 ]. 


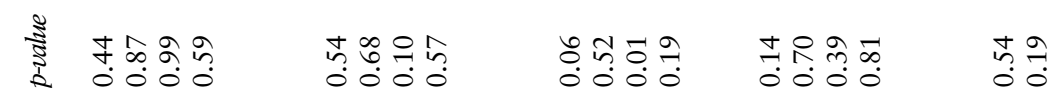

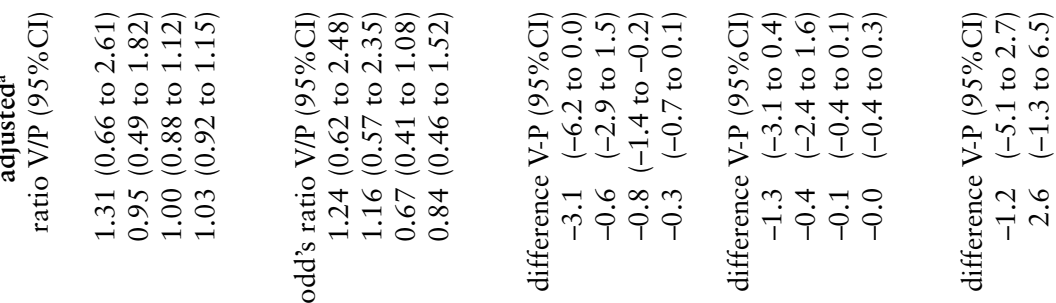

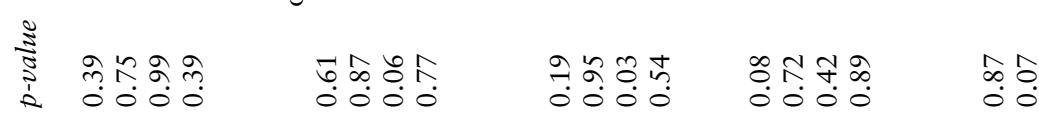

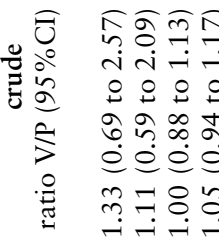

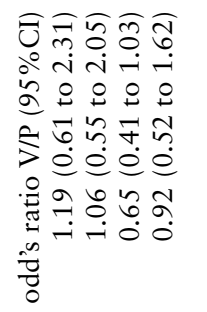

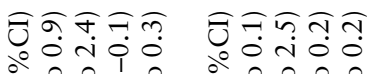
in 0 잉 0 in

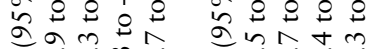

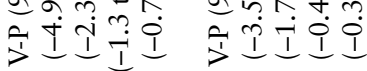

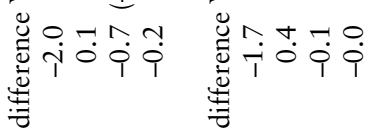

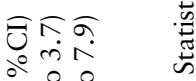

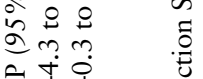
도포 옹

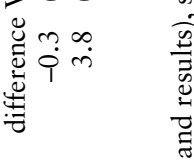

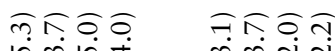

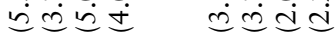

กิ ชี సீ人்

6. mini त)

Kล์

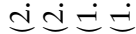

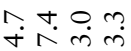

กิ ปे
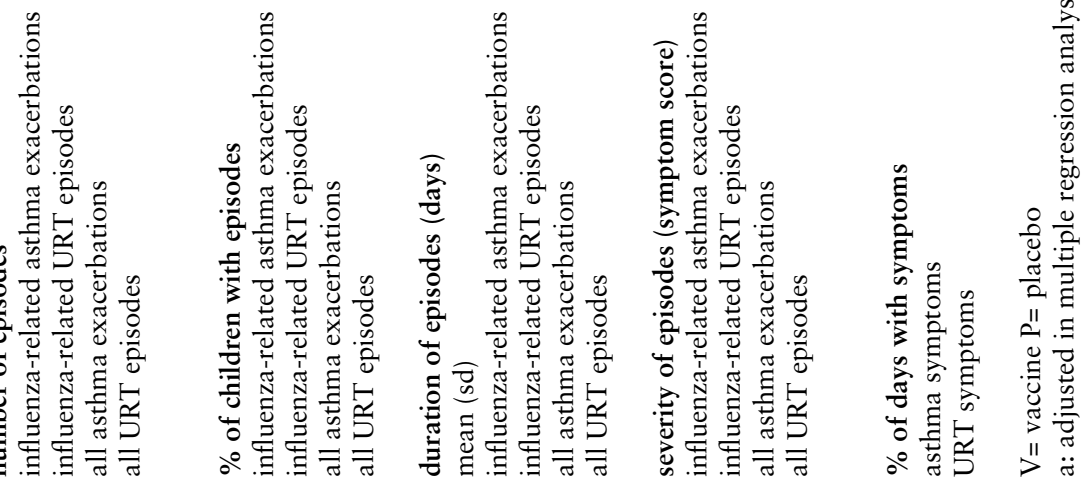
The mean length of an influenza-related asthma exacerbation was 9.2 (vaccine group) and 11.2 (placebo group) and after adjustment for confounders, 3.1 days longer in the placebo group $(\mathrm{p}=0.06)$. There were no differences in severity [TABLE 3] $(\mathrm{p}=0.11)$.

\section{Respiratory tract episodes}

From the diary data, 2311 asthma exacerbations and 2770 URT episodes were constructed [TABLE 3]. The mean length of all asthma exacerbations (irrespective of causative agent) was 0.8 days longer in the placebo group $(\mathrm{p}=0.01)$. There was no difference in number and severity of exacerbations, nor in number, duration and severity of URT episodes. The proportion of days with respiratory symptoms did not differ between groups: 26 versus $27 \%$ for asthma symptoms and 33 versus $29 \%$ for URT symptoms respectively for vaccine group and placebo group [TABLE 3].

Subgroup analysis by vaccination history did not reveal any differences between children that had been vaccinated before and those that were vaccinated for the first time.

\section{Medication, health care utilisation and absenteeism}

The use of various categories of medication (maintenance, relief, oral steroids, antibiotics, etc.) analysed both as number of doses, number of courses and proportion of days with medication, did not differ between the groups. Unscheduled visits to family doctor or specialist, and the number of absent days from school or work for participants and parents did not differ between the two groups. None of the children was admitted to hospital for airway problems.

One of the outcomes not reported in this paper, is quality of life during the asthma exacerbations. A paper describing the translation and validation of the questionnaire used to assess quality of life has been submitted. Another paper, studying various secondary outcomes in more detail, is in preparation.

\section{Serological results}

Blood samples were obtained on all three occasions from 651 children. A considerable number of children already had protective antibody levels $(\geq 40)$ before vaccination, due to previous vaccinations and/or natural infections (Table in chapter $4 \mathrm{~b}$ (additional methods and results)). Antibody levels and the proportion 
with antibody levels of at least 40 at 14-21 days after vaccination all showed differences in favour of the vaccine group. Comparing second and third samples, (taken two to three weeks after vaccination and at the end of the season) in the placebo group $17.5 \%$ of participants had at least a fourfold rise for $\mathrm{H} 1 \mathrm{~N} 1$, $4.0 \%$ for $\mathrm{H} 3 \mathrm{~N} 2$ and $0.9 \%$ for influenza $\mathrm{B}$, compared to $7.0 \%, 1.2 \%$ and $1.8 \%$, respectively, in the vaccine group.

\section{Adverse reactions}

During the first seven days after vaccination, injection site redness was reported significantly more often in the vaccine group than in the placebo group $(31 \%$ vs. $8 \%$ ), as were stiff or painful arms ( $65 \%$ vs. $25 \%)$ and myalgia ( $20 \%$ vs. $11 \%)$. We found no differences for reported airways symptoms during the first week, nor for medication use, health care utilisation and absenteeism.

\section{Discussion}

This study shows that influenza vaccination was not more effective than placebo in reducing the number of asthma exacerbations caused by influenza infections in children. The duration of influenza-related asthma exacerbations was three days shorter in the vaccine group, but this was not statistically significant. There was no difference in severity. Regarding the other secondary endpoints, vaccinated children had shorter exacerbations (irrespective of their cause) and fewer seroconversions than the placebo group, but reported more side effects. There was no difference in proportion of days with asthma symptoms.

For both seasons, the vaccine strain matched well with epidemic virus strains..$^{14,15}$ For children, the Dutch influenza bulletins reported a low number of influenza positive cases in 1999-2000 ${ }^{16}$ and a possible epidemic increase in 2000-2001, ${ }^{17}$ both of which are in accordance with our findings. The second season was unusual because of the relatively extensive circulation of subtype H1N1 and the low activity of subtype H3N2. ${ }^{15}$

We found no difference in the number of influenza-related asthma exacerbations between both groups, although the vaccine group had a significantly higher protective level of IgG. Is there a possible explanation for this lack of effect? Studies in healthy subjects have shown that parenteral inactivated influenza vaccine does not induce as good an IgA response in the mucous membranes of the respiratory tract (being the first line of defence) ${ }^{18}$ as does priming by natural infection or intranasally administered influenza vaccine. ${ }^{19-23}$ Hence, we speculate 
that parenteral vaccination may be relatively ineffective in preventing mucosal infection with influenza virus and subsequent asthma exacerbations.

After the 1986 study of Stenius-Aarniala ${ }^{24}$ this is the first randomised trial investigating parenteral influenza vaccination that takes influenza-related asthma exacerbations as an outcome. ${ }^{7}$ As the study of Stenius-Aarniala was unsuccessful due to extremely low influenza activity, we cannot compare our findings. Recent non-randomised studies in asthmatic children showed conflicting results. ${ }^{25-29}$ Was our study sample large enough? We were surprised by the low number of influenza-positive swabs, especially in the first season. Our choice to use pharyngeal swabs may have played a role, but compared to nasopharyngeal aspirates sensitivity is only about $20 \%$ lower. ${ }^{30}$ By recruiting more children than originally planned in the second season, we hoped to compensate for the low incidence in the first season. The final answer to the power question is given by our results, especially the $95 \%$ confidence interval for the primary endpoint. ${ }^{31}$ The interval ranges from $34 \%$ reduction to $161 \%$ increase. This firmly excludes a $50 \%$ reduction of influenza-related asthma exacerbations by vaccination, which we considered to be the threshold for clinical relevance.

Even a $35 \%$ reduction by vaccination is excluded by the confidence interval. Our finding of no difference is further corroborated by the lack of differences on almost all our other clinical outcome measures, as shown in TABLE 3 .

In previous studies, seroconversion throughout the influenza season was often the most important outcome measure to assess effectiveness of influenza vaccines. However, this outcome measure has serious shortcomings as a proxy measure for influenza infection. ${ }^{32}$ The most important problem is that seroconversion is more difficult or even impossible to attain in subjects with elevated titre levels at the start of the season. ${ }^{33}$

A closer look at the difference in mean duration of all asthma exacerbations revealed that extremely long episodes (more than three standard deviations above mean) were found more often in the placebo group than in the vaccine group $(n=12$ vs. $n=4)$. Most of these episodes began before influenza activity started in the Netherlands, which makes it likely that the difference in duration was a chance finding, not caused by the difference in treatment assignment.

Regarding adverse reactions, we found differences between groups for local symptoms (red or stiff arm) and myalgia, as reported in previous studies. ${ }^{33,34}$ There has been some debate about exacerbations as a direct result of vaccination. ${ }^{34,35} \mathrm{In}$ the present study, we found no differences in airway symptoms during the week after vaccination, making vaccination-induced airway symptoms unlikely.

We found relatively few influenza-related asthma exacerbations $(9.1 \%$ of all calls, 
$1.8 \%$ of all asthma exacerbations). Given the proportion of children that showed a fourfold increase of antibodies during the season, a considerable number of influenza infections apparently did not give symptoms, or gave symptoms that were not severe enough to pass our predefined threshold.

Inevitably, our episode definition, although used before, ${ }^{2}$ has arbitrary elements. Other cut-off points for the number of days between two episodes would give different results. For our primary endpoint, 4 children had two episodes related to the same throat swab that could be counted as one episode by stretching this criterion from 2 to 3 days. Three of these children were in the vaccine group. However, the reduction in number of episodes in the vaccine group as a consequence of changing this criterion (still negative, and the confidence interval still excluding a $50 \%$ reduction) would be balanced by an increase in length of the episodes.

In conclusion, our randomised placebo-controlled study showed no relevant effect of influenza vaccination on the number and severity of influenza-related asthma exacerbations in asthmatic children. Vaccinated children tended to have shorter exacerbations throughout the season but reported more (mild) adverse effects after vaccination than children receiving placebo.

Both the limited effectiveness of influenza vaccination found in this study and the low incidence of influenza, observed in the first season, warrant additional studies to justify routine influenza vaccination of asthmatic children in general practice.

\section{References}

1. Minor TE, Dick EC, DeMeo AN, et al. Viruses as precipitants of asthmatic attacks in children. JAMA 1974; 227: 292-8.

2. Johnston SL, Pattemore PK, Sanderson G, et al. Community study of role of viral infections in exacerbations of asthma in 9-11 year old children. BMJ 1995; 310: 1225-9.

3. Nicholson KG, Snacken R, Palache AM. Influenza immunization policies in Europe and the United States. Vaccine 1995; 13: 365-9.

4. Rothbarth PH, Kempen BM, Sprenger MJ. Sense and nonsense of influenza vaccination in asthma and chronic obstructive pulmonary disease. Am J Respir Crit Care Med 1995; 151: 1682-5.

5. Pai VA, Pai BV. Influenza vaccine. Where do we stand? Arch Dis Childh 2003; 88: 665.

6. Eisner MD. Asthma and influenza vaccination. Chest 2003; 124: 775-7. 
7. Cates CJ, Jefferson TO, Bara AI, Rowe BH. Vaccines for preventing influenza in people with asthma (Cochrane Review). In: The Cochrane Library; Oxford: Update Software, 2003.

8. Kramarz P, DeStefano F, Gargiullo PM, Davis RL, et al. Influenza vaccination in children with asthma in health maintenance organizations. Vaccine Safety Datalink Team. Vaccine 2000; 18: 2288-94.

9. Fiebach NH, Viscoli CM. Patient acceptance of influenza vaccination. Am J Med 1991; 91: 393-400.

10. Meynaar IA, van 't Wout JW, Vandenbroucke JP, van Furth R. De opvattingen van huisartsen en specialisten over de vaccinatie tegen influenza. [Opinions of family physicians and specialists on vaccination against influenza]. Ned Tijdschr Geneeskd 1992; 136: 176-9.

11. Bueving HJ, Bernsen RMD, de Jongste JC, et al. Influenza vaccination in asthmatic children: randomized double-blind placebo-controlled trial. [abstract] ERS, Stockholm, 2002.

12. Bueving HJ, Bernsen RMD, de Jongste JC, et al. Influenza vaccination in asthmatic children: randomized double-blind placebo-controlled trial. [abstract] WONCA Europe, London, 2002.

13. Van der Wouden JC, Bueving HJ, Bernsen RMD, et al. Influenza vaccination in asthmatic children: randomized double-blind placebo-controlled trial. [abstract] Am J Resp Crit Care Med 2003; 167: A785.

14. Rimmelzwaan GF, de Jong JC, Bartelds AI, et al. Het influenzaseizoen 1999/2000 en de vaccin-samenstelling voor het seizoen 2000/01. [Influenza season 1999/2000 and vaccine composition for season 2000/01]. Ned Tijdschr Geneeskd 2000; 144: 1968-71.

15. de Jong JC, Rimmelzwaan GF, Bartelds AI, et al. Het influenzaseizoen 2000/'01 en de vaccinsamenstelling voor het seizoen 2001/'02. [Influenza season 2000/'01 and vaccine composition for season 2001/'02]. Ned Tijdschr Geneeskd 2001; 145: $1945-50$.

16. Nationaal Influenza Centrum (NIC): Rotterdam; Rijksinstituut voor Volksgezondheid en Milieu (RIVM): Bilthoven; Nederlands instituut voor onderzoek van de gezondsheidszorg (NIVEL); Inspectie voor de gezondheidszorg (IGZ). Nieuwsbrief influenza-surveillance [Newsletter influenza surveillance] 1999/2000; 8(Pt 8).

17. Nationaal Influenza Centrum (NIC): Rotterdam; Rijksinstituut voor Volksgezondheid en Milieu (RIVM): Bilthoven; Nederlands instituut voor onderzoek van de gezondsheidszorg (NIVEL); Inspectie voor de gezondheidszorg (IGZ). Nieuwsbrief influenza-surveillance [Newsletter influenza surveillance] 2000/01; 9(Pt 5). 
18. Gerhard W. The role of the antibody response in influenza virus infection. Curr Top Microbiol Immunol 2001; 260: 171-90.

19. Johnson PR, Feldman S, Thompson JM, et al. Immunity to influenza A virus infection in young children: a comparison of natural infection, live cold-adapted vaccine, and inactivated vaccine. J Infect Dis 1986; 154: 121-7.

20. Ghendon Y. The immune response to influenza vaccines. Acta Virol 1990; 34: 295-304.

21. el-Madhun AS, Cox RJ, Soreide A, et al. Systemic and mucosal immune responses in young children and adults after parenteral influenza vaccination. J Infect Dis 1998; 178: 933-9.

22. Brokstad KA, Eriksson JC, Cox RJ, et al. Parenteral vaccination against influenza does not induce a local antigen-specific immune response in the nasal mucosa. J Infect Dis 2002; 185: 878-84.

23. Beyer WE, Palache AM, de Jong JC, Osterhaus AD. Cold-adapted live influenza vaccine versus inactivated vaccine: systemic vaccine reactions, local and systemic antibody response, and vaccine efficacy. A meta-analysis. Vaccine 2002; 20: 1340-53.

24. Stenius-Aarniala B, Huttunen JK, Pyhala R, et al. Lack of clinical exacerbations in adults with chronic asthma after immunization with killed influenza virus. Chest 1986; 89: 786-9.

25. Sugaya N, Nerome K, Ishida M, et al. Efficacy of inactivated vaccine in preventing antigenically drifted influenza type A and well-matched type B. JAMA 1994; 272: $1122-6$.

26. Neuzil KM, Wright PF, Mitchel EF, Jr, Griffin MR. The burden of influenza illness in children with asthma and other chronic medical conditions. J Pediatr 2000; 137: 856-64.

27. Izurieta HS, Thompson WW, Kramarz P, et al. Influenza and the rates of hospitalization for respiratory disease among infants and young children. N Engl J Med 2000; 342: 232-9.

28. Kramarz P, Destefano F, Gargiullo PM, et al. Does influenza vaccination prevent asthma exacerbations in children? J Pediatr 2001; 138: 306-10.

29. Smits AJ, Hak E, Stalman WA, et al. Clinical effectiveness of conventional influenza vaccination in asthmatic children. Epidemiol Infect 2002; 128: 205-11.

30. Covalciuc KA, Webb KH, Carlson CA. Comparison of four clinical specimen types for detection of influenza A and B viruses by optical immunoassay (FLU OIA test) and cell culture methods. J Clin Microbiol 1999; 12: 3971-4.

31. Altman DG, Moher D, Schulz KF. Peer review of statistics in medical research. Reporting power calculations is important. BMJ 2002; 325: 491. 
32. Demicheli V, Rivetti D, Deeks JJ, Jefferson TO. Vaccines for preventing influenza in healthy adults (Cochrane Review). In: The Cochrane Library; Oxford: Update Software, 2002.

33. Edwards KM, Dupont WD, Westrich MK, et al. A randomized controlled trial of cold-adapted and inactivated vaccines for the prevention of influenza A disease. J Infect Dis 1994; 169: 68-76.

34. The American Lung Association Asthma Clinical Centers. The safety of inactivated influenza vaccine in adults and children with asthma. N Engl J Med 2001; 345: 1529-36.

35. Nicholson KG, Nguyen-Van-Tam JS, Ahmed AH, et al. Randomised placebocontrolled crossover trial on effect of inactivated influenza vaccine on pulmonary function in asthma. Lancet 1998; 351: 326-31. 


\section{Chapter $4 b$}

Influenza vaccination in children with asthma: randomised double-blind placebo-controlled trial, additional methods and results

American Journal of Respiratory and Critical Care Medicine 2004 169: 488-93, online data supplement.

Bueving HJ, Bernsen RMD, de Jongste JC, van Suijlekom-Smit LWA, Rimmelzwaan GF, Osterhaus ADME, Rutten-van Mölken MPMH, Thomas S, van der Wouden JC. 


\section{4b. Influenza vaccination in children with asthma: randomised double-blind placebo-controlled trial, additional methods and results}

\section{Inclusion}

Possible participants were selected from computerised patient files by means of a preinstalled influenza prevention module, searching for asthma diagnoses and drug prescriptions specific for asthma. ${ }^{1}$ In the months August to October preceding the respective influenza seasons, eligible patients were visited and included if they had used maintenance therapy for asthma or more than 52 doses of relief medication during the previous 12 months.

Exclusion criteria were diabetes, thyroid diseases, cystic fibrosis, kidney diseases, Down's syndrome, congenital heart diseases and other chronic diseases for which influenza vaccination is advised, with the exception of asthma. Insufficient understanding of Dutch language resulted in exclusion for reasons of compliance and allergy to chicken protein did, because the antigens for influenza vaccines are produced in embryonated chicken eggs.

Research nurses were instructed and trained to perform inclusion visits, explain the objectives of our study and the use of the diaries, take throat swabs, use spirometers, give intramuscular injections and draw blood from children.

At the inclusion visit they measured height and weight and performed spirometry. Lidocaine-prilocaine plasters were provided to reduce pain of drawing blood.

\section{Vaccine and placebo}

The vaccine composition for 1999-2000 was a combination of A/Sydney/5/97 H3N2-like, A/Beijing/262/95 H1N1-like and B/Beijing/184/93-like strains and for 2000-2001 A/ Moscow/10/99 H3N2-like, A/New Caledonia/20/99 H1N1-like and B/Beijing/184/93like strains as advised by the World Health Organisation. The placebo consisted of a buffered phosphate solution with the same $\mathrm{pH}$ value and was similar in appearance to the inactivated influenza vaccine. The manufacturer (Solvay Pharmaceutical Products, Weesp, the Netherlands) stored the vaccines after production at 2 to $8{ }^{\circ} \mathrm{C}$. Vaccines were transported to and stored under optimal conditions at the central pharmacy of the University Hospital Rotterdam until shortly before vaccination. 


\section{Outcomes}

In addition to the outcomes mentioned in chapter 4A, we also studied proportion of days with symptoms of upper respiratory tract and/or lower respiratory tract (LRT), use of medication, unscheduled consultations of a specialist or family physician, admittance to hospital for airway problems, a rise in antibody-titre against influenza, and the number of influenza infections indicated by serology.

\section{Respiratory tract symptoms and episodes}

URT symptoms included sneezing, runny or stuffy nose, burning or watery eyes, sore throat, hoarseness, fever or shivering, headache, myalgia. LRT symptoms (asthma symptoms) included cough and wheeze during day and night, difficult breathing or shortness of breath. Respiratory tract symptoms were scored from 1 (mild) to 3 (severe) and summated; not fit to go to school or work because of symptoms was scored as 2. Participants were instructed to phone the investigators when scores for upper or lower airway symptoms totalled 4 or more on a given day. As soon as possible, but within 48 hours after the call, a research nurse visited these children and took a pharyngeal swab. Nurses were instructed to rub the swab two times along the palatoglossal arch including the uvula.

All diary data were coded and entered into a database. For every child we calculated medians for URT and LRT symptoms over the period starting one week after vaccination and ending when diaries were returned (around the 1 st of April). Symptoms scored in the first week were excluded because these were considered to be side effects of the vaccination.

A call reporting a symptom score of 4 or more was considered to coincide with an episode of URT symptoms if it occurred during the episode of URT symptoms. A call was considered to coincide with an asthma exacerbation if it occurred during or up to seven days before the asthma exacerbation. Severity was defined as the highest day score during the episode. When influenza virus was detected in the pharyngeal swab by any of the detection methods (see below) we assumed that the episode coinciding with the call was caused by this pathogen.

\section{Virological assessments}

Throat swabs were placed in $1 \mathrm{ml}$ modified Eagles minimal essential medium supplemented with $500 \mathrm{U} / \mathrm{ml}$ penicillin, $500 \mathrm{~g} / \mathrm{ml}$ streptomycin (all BioWhittaker) and $5 \mathrm{~g} / \mathrm{ml}$ amphotericin B (Bristol Meyers Squibb). The swabs were transported 
in a cool box and delivered at the laboratory within 36 hours. $0.2 \mathrm{ml}$ of swab aspirate was transferred to shell vial cultures of human pharynx carcinoma cells, tertiary monkey kidney cells and human embryonic lung cells in 24 well plates. The plates were centrifuged at $3500 \mathrm{x}$ g for 15 minutes, washed and subsequently cultured in culture medium at $37^{\circ} \mathrm{C}$ and $5 \% \mathrm{CO}_{2}$. The cultures were checked for cytopathologic effects daily. After 24-48 hours of culture, the coverslips of cells were removed from the shell vials, washed three times in phosphate buffered saline and fixed in acetone for $15 \mathrm{~min}$ at room temperature. Subsequently they were analyzed by immunofluorescence for respiratory viruses using specific reagents (Dako, Glostrup, Denmark).

For reverse transcriptase polymerase chain reaction (RT-PCR), RNA was extracted from clinical samples using the high pure RNA isolation kit (Roche Molecular Biochemicals) and used as template. RT-PCR and subsequent dotblot hybridizations were performed as described previously for the detection of influenza A viruses. ${ }^{2}$ For influenza $\mathrm{B}$, the following primers and probes were used: Primer forward (5'-ATG GCC ATC GGA TCC TCA AC) and primer reverse (5'-TGT CAG CTA TTA TGG AGC TG) for PCR amplification, hybridisation probe (5'-CAA GAG CAC CGA TTA TCA CCA GAA GAG GGA).

\section{Serology}

We took blood samples (4 cc) before vaccination (sample 1), 14-21 days afterwards (sample 2) and at the end of the season, around the 1st of April (sample 3). Samples were kept at room temperature and delivered at the laboratory within 72 hours.

For the detection of influenza virus specific serum antibodies a hemagglutination inhibition assay (HIA) was used, which was performed essentially as described previously, ${ }^{3,4}$ using turkey erythrocytes for agglutination, a filtrate of cholera vimbriae as source of receptor destroying enzyme and four hemagglutinating units of the respective vaccine strains (X-127 (reassortant of A/Beijing/262/95(H1N1)), IVR-108 (reassortant of A/Sydney/005/97 (H3N2) and B/Yamanashi/166/98 for the 1999-2000 season and strains IVR-116 (reassortant of A//New Caledonia/ 020/99(H1N1)), ResVir-17 (reassortant of A/Panama/2007/99 (H3N2)) and B/Yamanashi/166/98 for the 2000-2001 season), which were propagated in embryonated chicken eggs. Geometric mean titres (GMT) were calculated, as recommended for antibody titre data. A post-vaccination titre of at least 40 was considered to be a protective antibody level. ${ }^{5}$

A four-fold increase in post-season serum antibody titre (comparing sample 2 and 
3) was considered an indication for an influenza virus infection [TABLE].

TABLE. SEROLOGICAL RESULTS

vaccine placebo p-value

Number of samples

Sample 1 before vaccination 341

346

Sample 2 two weeks after vaccination

343

Sample 3 end of the season

328

H1N1

Sample 1 antibody titre (geometric mean)

23.2

Sample 2 antibody titre (geometric mean)

200.7

23.0

$<0.001$

Sample 3 antibody titre (geometric mean)

188.0

38.0

$<0.001$

Sample 1, titre $>40$

$38.7 \%$

$38.4 \%$

a

comparing samples 1 and 2 , fourfold increase

$59.9 \%$

$0.9 \%$

$<0.001$

sample 2 , titre $>40$

$85.6 \%$

$38.9 \%$

$<0.001$

comparing samples 2 and 3 , fourfold increase

$7.0 \%$

$17.5 \%$

$<0.001$

H3N2

sample 1 antibody titre (geometric mean)

87.2

78.9

$a$

79.4

$<0.001$

186.3

88.3

$<0.001$

sample 3 antibody titre (geometric mean)

$78.3 \%$

$79.2 \%$

$a$

$27.1 \%$

$1.2 \%$

$<0.001$

$98.5 \%$

$79.2 \%$

$<0.001$

$1.2 \%$

$4.0 \%$

0.03

comparing samples 2 and 3, fourfold increase

.

B

sample 1 antibody titre (geometric mean)

159.7

155.7

$a$

sample 2 antibody titre (geometric mean)

358.4

157.6

$<0.001$

sample 3 antibody titre (geometric mean)

338.4

156.6

$<0.001$

sample 1 , titre $>40$

$88.3 \%$

$87.9 \%$

a

$26.5 \%$

$0 \%$

$<0.001$

$95.3 \%$

$87.7 \%$

$<0.001$

sample 2 , titre $>40$

$1.8 \%$

$0.9 \%$

0.26

$a$ : differences at baseline not tested as these are the result of randomisation

\section{Adverse effects}


Symptoms scored in the diaries during the first seven days after vaccination were considered to be adverse effects of the vaccination. Additionally, we asked during these seven days for red or painful arm, nausea, vomiting or diarrhoea, fatigue or sweating, other symptoms, contact with a physician, use of medication for these symptoms and absence from school or work for participants as well as for their parents.

A separate paper studying adverse effects in more detail has been submitted.

\section{Spirometry}

Forced expiratory volume in one second $\left(\mathrm{FEV}_{1}\right)$ was performed at inclusion. We used a hand-held spirometer (Micro DL, Micro Medical Systems, Rochester, UK). Each time, the best result of three attempts was taken. Values were expressed as percentage of predicted values according to age, sex and height. ${ }^{6}$

\section{Sample size}

Sample size calculations were based on crude proportions, and did not take account of multivariate adjusting. We wanted to be able to detect a $50 \%$ reduction in the number of asthma exacerbations caused by influenza virus with $\alpha=0.05$ and $\beta=0.2$ (two-sided test). Reported infection rates, mainly based on serological data, have usually been in the range of $20-40 \%$ and were higher for children than for adults. ${ }^{7-9}$ Foy found that $40-54 \%$ of adolescents with serological evidence of infection reported clinical illness. ${ }^{10}$

Therefore, we assumed that $50 \%$ of infected children would react with an exacerbation.

To allow for variation in both incidence and effectiveness, we chose to aim at a total number of 600 children for whom complete data would be available, i.e. 300 children per season. This would allow us to show $50 \%$ reduction when $15 \%$ of the children in the placebo group would show influenza-related exacerbations (30\% influenza incidence and $50 \%$ of these children with exacerbation).

In the first season, we obtained data from 297 children. However, only eight positive throat swabs were found, which is much less than we expected. Because of this we seriously considered to stop the study. Data from the National Influenza Centre made clear, however, that the season had been atypical because of the low influenza activity in children.

After careful consideration of various scenarios we decided to continue and make 
an effort to include more participants during the second season. We aimed at recruiting as many children as possible with the available personnel, and ended up with exactly 400 children, giving a total of 697 children.

\section{Randomisation}

Randomisation took place by the manufacturer when packing vaccine and placebo, from a computer-generated list. We randomised patients in blocks and stratified for vaccination in the past, because this may be a confounder for vaccine efficacy. ${ }^{11,12}$ Randomisation codes were stored by the manufacturer and in sealed envelopes at the central pharmacy of the University Hospital Rotterdam. The pharmacist was not involved in outcome assessment or data analysis.

\section{Blinding}

Patients and parents, general practitioners, research nurses and investigators were all blinded. Randomisation codes were broken after completion of the analyses.

\section{Statistical methods}

We analysed the results by intention to treat. No interim analyses were performed. Differences in proportions were tested by $\chi^{2}$-tests (Fisher's exact test). The ratio (vaccine/placebo) of the number of episodes and of the number of medication courses (oral prednisone and antibiotics) was estimated; the null hypothesis of no difference was tested by means of Poisson regression (robust SE). Differences between groups in occurrence of episodes (yes/no) were tested by means of logistic regression analysis. Differences in length and severity of episodes between groups were tested by means of linear regression for repeated measurements, taking children with episodes as units of analysis. Differences between groups in proportion of days with symptoms, medication, physician visits, number of absent days and number of doses medication was tested by means of linear regression analysis. The difference between groups for occurrence of symptoms during the first seven days after vaccination was tested by logistic regression for repeated measurements. Baseline characteristics that had at least a weak relation $(\mathrm{p}<0.25)$ with the outcome variables were considered to be potential confounders. The adjustments for these potential confounders were made through relevant multiple regression models. Serological data were analysed univariately by means 
of $\chi^{2}$-tests (in case of proportions) and analysis of variance (titre levels). All tests were two-sided with a significance level of 0.05 .

\section{References}

1. Hak E, Hermens RP, van Essen GA, et al. Population-based prevention of influenza in Dutch general practice. Br J Gen Pract 1997; 47: 363-6.

2. Fouchier RA, Bestebroer TM, Herfst S, et al. Detection of influenza A viruses from different species by PCR amplification of conserved sequences in the matrix gene. J Clin Microbiol 2000; 38: 4096-101.

3. Palmer DF, Dowdle WR, Coleman MT, Schild GC. Haemagglutination inhibition test. In: Advanced laboratory techniques for influenza diagnosis; Procedural guide. Atlanta, US: Department of Health and Welfare 1975: 25-62.

4. Masurel N, Ophof P, de Jong P. Antibody response to immunization with influenza A/ USSR/77 (H1N1) virus in young individuals primed or unprimed for A/New Jersey/76 (H1N1) virus. J Hyg (Lond) 1981; 87: 201-9.

5. The European Agency for the Evaluation of Medicinal Products (EMEA)(UK), Human Medicines Evaluation Unit, Committee for Proprietary Medicinal Products(CPMP). Note for guidance on harmonisation of requirements for influenza vaccines. London: EMEA; 1997.

6. Quanjer PH, Borsboom GJ, Brunekreef B, et al. Spirometric reference values for white European children and adolescents: Polgar revisited. Pediatr Pulmonol 1995; 19: $135-42$.

7. Gruber WC, Taber LH, Glezen WP, et al. Live attenuated and inactivated influenza vaccine in school-age children. Am J. Dis Child 1990; 144: 595-600.

8. Monto AS, Koopman JS, Longini IM, Jr. Tecumseh study of illness. XIII. Influenza infection and disease, 1976-1981. Am J Epidemiol 1985; 121: 811-22.

9. Fox JP, Hall CE, Cooney MK, Foy HM. Influenzavirus infections in Seattle families, 1975-1979. I. Study design, methods and the occurrence of infections by time and age. Am J Epidemiol 1982; 116: 212-27.

10. Foy HM, Cooney MK, Allan I. Longitudinal studies of types A and B influenza among Seattle schoolchildren and families, 1968-74. J Infect Dis 1976; 134: 362-9.

11. Hoskins TW, Davies JR, Smith AJ, et al. Assessment of inactivated influenza-A vaccine after three outbreaks of influenza A at Christ's Hospital. Lancet 1979; 1: 33-5.

12. Keitel WA, Cate TR, Couch RB. Efficacy of sequential annual vaccination with inactivated influenza virus vaccine. Am J Epidemiol 1988; 127: 353-64. 


\section{Chapter 5}

Responsiveness, longitudinal and crosssectional construct validity of the Pediatric Asthma Quality of Life Questionnaire (PAQLQ) in Dutch children with asthma

Quality of Life Research 2005; 14: 265-272.

Raat H, Bueving HJ, de Jongste JC, Grol MH, Juniper EF, van der Wouden JC. 


\section{Responsiveness, longitudinal and cross-sectional construct validity of the Pediatric Asthma Quality of Life Questionnaire (PAQLQ) in Dutch children with asthma}

\section{Abstract}

Health-related quality of life is an important measure in evaluations of the management of childhood asthma. In this study, we assessed psychometric properties, responsiveness, and longitudinal and cross-sectional construct validity of the Dutch version of the 23-item Pediatric Asthma Quality of Life Questionnaire (PAQLQ).

The study group consisted of 238 6-18 year-olds with asthma, with complete respiratory symptom diaries and at least two PAQLQ measurements (one relating to a week with relatively few, and one to a week with relatively many symptoms) during one winter season. The PAQLQ scores for a week with few symptoms (the symptom diary scores remained below a predefined level everyday) were compared with the PAQLQ scores for a week with many symptoms (on day 1 , symptom diary scores were above the predefined level). Additionally, the PAQLQscores for two subsequent periods with many symptoms were compared in 101 children.

Only the domain Emotions showed a ceiling effect ( $>25 \%$ had the maximum score). All Cronbach's $\alpha$ 's of the PAQLQ total score and domains were $>0.70$, except for Activities. Mean PAQLQ-score changes between periods with few versus many symptoms $(n=238)$ were significantly different $(\mathrm{p}<0.01)$ from changes between two consecutive periods with many symptoms $(n=101)$, which indicates responsiveness. (Changes in) lower respiratory tract symptoms, indicative of asthma severity, correlated better with (changes in) PAQLQ scores than (changes in) upper respiratory tract symptoms, which supports the longitudinal and crosssectional construct validity.

The assessed properties of the PAQLQ linguistic validation into Dutch were similar to those originally established for the PAQLQ in Canada. This study 
showed that the Dutch PAQLQ has adequate psychometric properties, excellent responsiveness, and that the longitudinal and cross-sectional construct validity is supported.

\section{Introduction}

Health-related quality of life is an important measure, complementary to clinical and physiological parameters, in evaluations of the management of childhood asthma, ${ }^{1-9}$ a very prevalent chronic condition. ${ }^{10}$ The Pediatric Asthma Quality of Life Questionnaire (PAQLQ), developed by Juniper et al., is a widely used disease-specific health-related quality of life measure for children and adolescents aged 7-17 years. ${ }^{3,11}$ It has 3 domains: symptoms (10 items), activity limitations (5 items), and emotional function ( 8 items). ${ }^{3}$ All items have 7 response options. Usually, the mean item score (or change in mean score) is reported per domain and for the whole instrument. Scores range from 1-7, where higher scores indicate better quality of life. ${ }^{3}$

The PAQLQ was first applied in Canada and has since been used in several other countries. ${ }^{3,12-15}$ A PAQLQ linguistic validation into Dutch was performed following a rigorous process including two independent forward and backward translations and a cognitive debriefing on 10 children with asthma. ${ }^{16-18}$ This study aims to evaluate the Dutch PAQLQ by assessing:

(a) psychometric properties (score distributions to assess floor and ceiling effects; internal consistency of the domains; test-retest reliability);

(b) evaluative properties (ability to detect changes between periods with differences in reported respiratory symptoms as indicator of responsiveness; correlation coefficients between changes in reported respiratory symptoms plus other indices of severity and changes in PAQLQ scores as indicator of longitudinal construct validity); ${ }^{19}$

(c) discriminative properties (correlation coefficients between the level of reported respiratory symptoms plus other indices of severity at a point in time and PAQLQ scores at that time as indicator of cross-sectional construct validity). ${ }^{19}$

The PAQLQ cross-cultural adaptation into Dutch will be regarded as successful when the PAQLQ measurement properties are similar to those that were originally found in Canada and other countries. . $^{32-15,20}$ 


\section{Methods}

\section{Study population and data collection}

The study group consisted of 238 6-18 year-olds with asthma, with complete respiratory symptom diaries and at least two PAQLQ measurements (one relating to a week with relatively few, and one to a week with relatively many symptoms) during one winter season (1999-2000 or 2000-2001); the study population was drawn from 696 children with asthma selected from 144 general practices who were included in a randomised double-blind placebo-controlled trial of influenza vaccination. ${ }^{21}$ During the year previous to inclusion, all had used asthma maintenance therapy or more than 52 doses of relief medication.

Socio-demographic variables, age at asthma onset, history of allergy, medication and $\mathrm{FEV}_{1}-\%$ predicted ${ }^{22}$ were assessed at inclusion; the results are shown in TABLE I. Upper- and lower respiratory tract (URT and LRT) symptoms and use of $\beta$-agonists were recorded in the respiratory symptom diaries. URT symptoms included sneezing, runny/stuffy nose, burning/watery eyes, sore throat, hoarseness, fever/shivering, headache, and myalgia. LRT (asthma) symptoms included cough and wheeze during day and night, difficult breathing or shortness of breath. Symptoms were scored from 1 (mild) to 3 (severe) and summated; not fit to go to school/work because of symptoms was scored as $2 .{ }^{21}$

If URT or LRT scores totalled 4 or more on a certain day, participants were instructed to phone the research nurse, who -within 48 hours- assessed FEV $_{1}-\%$ predicted $^{22}$ and -after 7 days- assessed the PAQLQ for the preceding week (referred to as a period with many symptoms). The participants were also visited for 'baseline' measurements of $\mathrm{FEV}_{1}-\%$ predicted ${ }^{22}$ and PAQLQ evaluation over a period with few symptoms ( 7 consecutive days during which symptom diary scores were below 4 URT/LRT-points on all days).

Pairs of PAQLQ scores, made up of a period with few and a period with many respiratory symptoms, were established and assessed for the 238 participating children, with random selection of the period with many symptoms in the event a child had reported experiencing two or more periods with many symptoms. Additionally, a subgroup of 101 children was distinguished from whom two (or more) consecutive PAQLQ measurements of periods with many symptoms had been obtained; two periods/measurements were randomly selected if a child had reported three or more periods with many symptoms. We evaluated pairs of PAQLQ-scores relating to two consecutive periods with many symptoms for these 101 children. 
TABLE I. CHARACTERISTICS OF THE STUDY GROUP $(n=238)$

Variable mean of participants $\quad n$ (SD)

Age group (years)

$\begin{array}{lrr}6-10 & 137 & 57.6 \\ 11-14 & 68 & 28.6 \\ 15-18 & 33 & 13.9 \\ \text { Mean (SD) } & & \end{array}$

Mean (SD)

10.8

Gender

Girls

50.8

Mean age (years) at asthma onset (SD)

$\mathrm{FEV}_{1}-\%$ predicted (at inclusion)

$<80 \%$

$\geq 80 \%$

183

78.2

Mean (SD)

$88.7 \%$

$\mathrm{FEV}_{1}-\%$ predicted (at a day with symptoms-diary-score below the predefined level)
$<80 \%$
40
17.5
$\geq 80 \%$
189
82.5

Mean (SD)

$92.9 \%$

$\mathrm{FEV}_{1-}-\%$ predicted (at a day with symptoms-diary-score above the predefined level)

$\begin{array}{lrr}<80 \% & 75 & 34.2 \\ \geq 80 \% & 144 & 65.8 \\ \text { Mean (SD) } & & \end{array}$

34.2

65.8

Mean (SD)

$84.5 \%$

Child has history of allergy

Yes

127

53.3

Child has used inhalation steroids during 12 months prior to inclusion

Yes

92.9

Child born in the Netherlands

Yes

99.2

Parents sharing household

Yes

94.1

Educational level of mother

$\begin{array}{lrr}\text { Elementary school } & 7 & 3.0 \\ \text { Secondary education } & 188 & 80.7 \\ \text { Higher education/university } & 38 & 16.3\end{array}$


We assessed PAQLQ score distributions to evaluate floor and ceiling effects, arbitrarily defined as $>25 \%$ of the respondents having the maximum respectively minimum score, ${ }^{23}$ and Cronbach's $\alpha$ 's as measure of internal consistency of the domains. ${ }^{24}$ Testretest reliability was evaluated preliminarily by Intraclass Correlation Coefficients (ICCs) ${ }^{25}$ between scores at two periods with many symptoms ( $n=101$; see Discussion). Responsiveness was evaluated by assessing the mean change in PAQLQ scores between a period with few and a period with many symptoms $(n=238)$. This was contrasted with the mean change between two periods with many symptoms $(n=101)$. Mean change was tested by two-sided Wilcoxon's signed ranks tests. Cohen's effect size was used to indicate the relative magnitude of change: $d=[\operatorname{Mean}(\mathrm{a})-\operatorname{Mean}(\mathrm{b})] / \mathrm{SD}$ concerning a period with many symptoms, respectively the 2 nd measurement* ${ }^{26}$ The mean change between few versus many symptoms was compared with the change between two periods with many symptoms; this was tested by 2-sided Mann-Whitney $\mathrm{U}$ tests. Longitudinal construct validity was evaluated by assessing Spearman rank order correlation coefficients between the change in URT/LRT-symptoms/ $\beta$-agonist use/ $\mathrm{FEV}_{1}-\%$ predicted and PAQLQ changes $(n=238)$. Cross-sectional construct validity was evaluated by assessing Spearman rank order correlation coefficients between URT/LRT diary-scores/ $\beta$-agonist use/FEV ${ }_{1}-\%$ predicted and PAQLQ scores. This was performed for measurements relating to both periods with few symptoms $(n=238)$ as well as periods with many symptoms ( $n=238$ ); so, with regard to 476 measurements.

All analyses were done in SPSS, Version 10.0. Parents/children gave informed consent; the Medical Ethical Committee of Erasmus MC-University Medical Center Rotterdam approved the study.

\section{Results}

\section{Psychometric properties}

There was no evidence of any ceiling or floor effect for the PAQLQ total score and the domain scores, except for the Emotional function domain [TABLE 2]. Cronbach's $\alpha$ 's of the PAQLQ overall score and the domain scores were all above 0.70 indicating excellent internal consistency, except for Activities $(\alpha$ $<0.70)$ [TABLE 2]. Test-retest ICCs between two periods with many symptoms, were generally low (defined as $<0.50)$ or moderate $(0.50-0.75)$, and one time excellent $(>0.75)^{27}$ [TABLE $3 \mathrm{~A}$ ].

\footnotetext{
* Following Cohen's guidelines, $0.2 \leq d<0.5$ indicates a small effect, $0.5 \leq d<0.8$ a moderate effect and $d \geq 0.8$ a large effect. ${ }^{26}$
} 


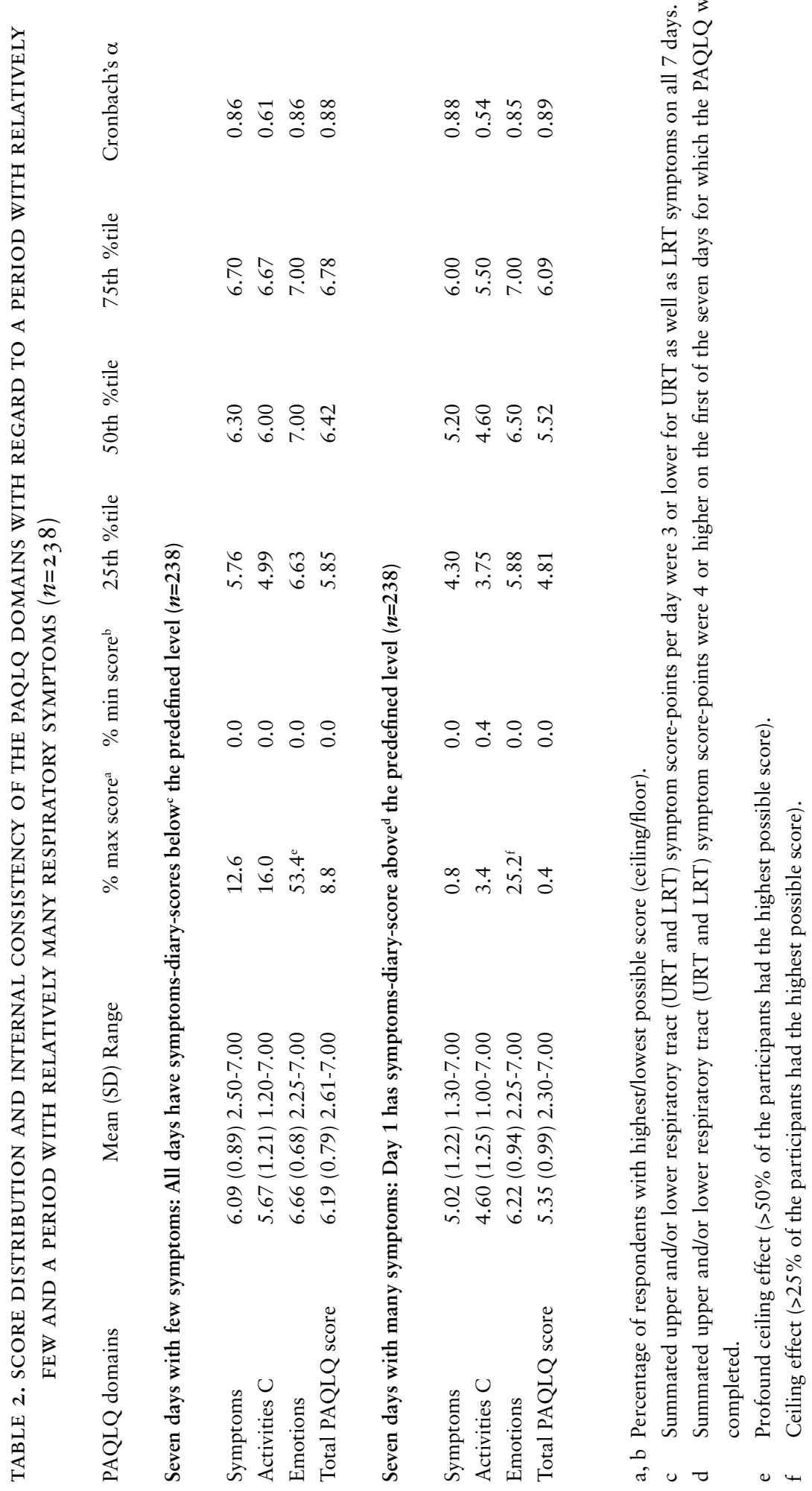




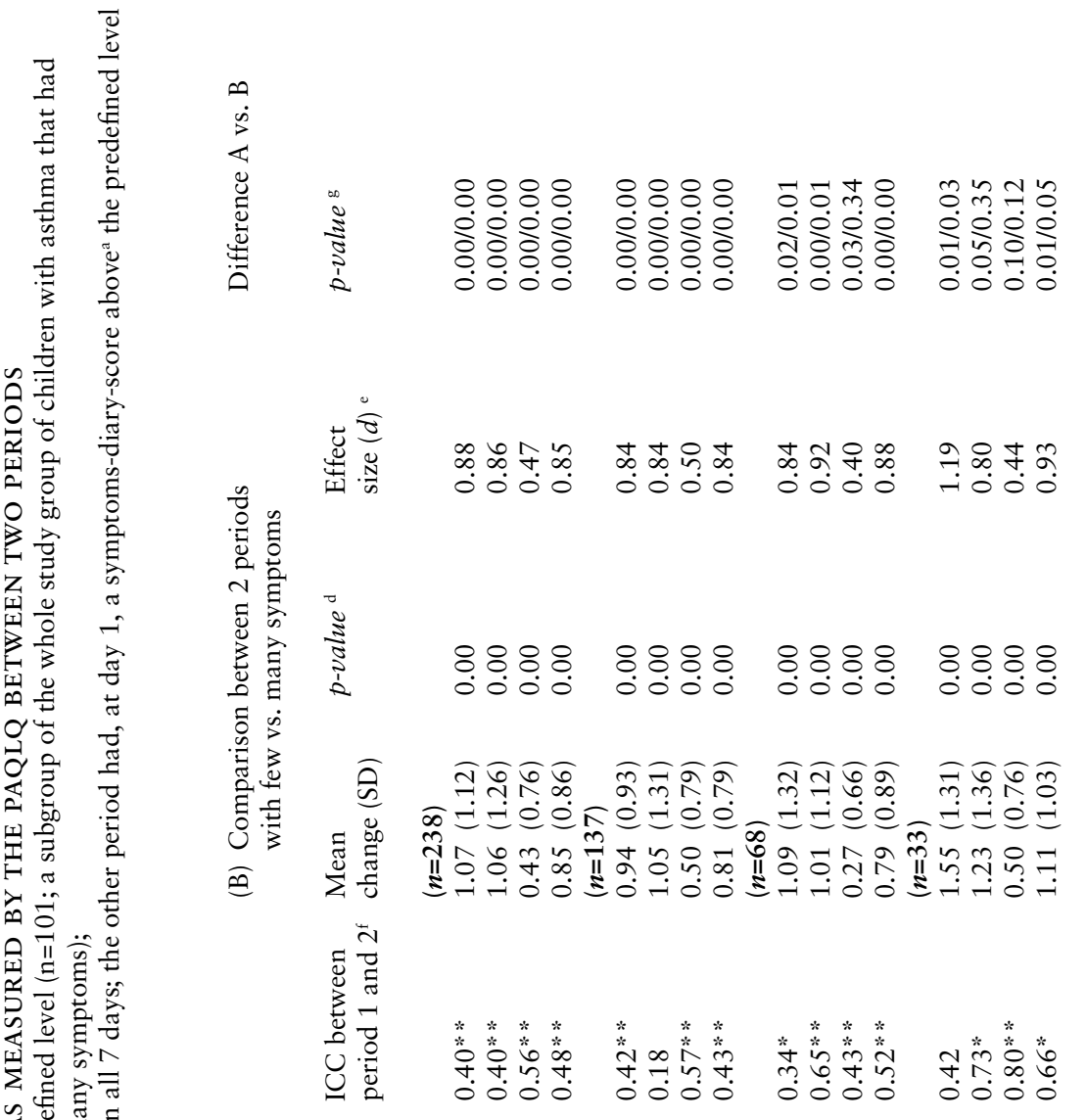

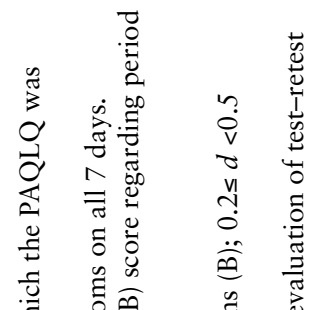

ह

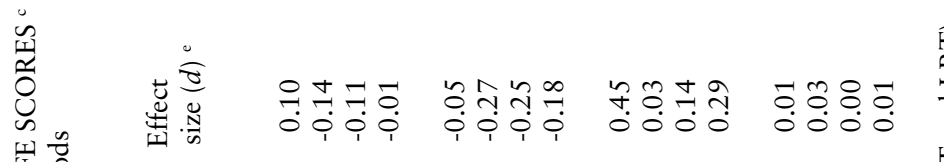

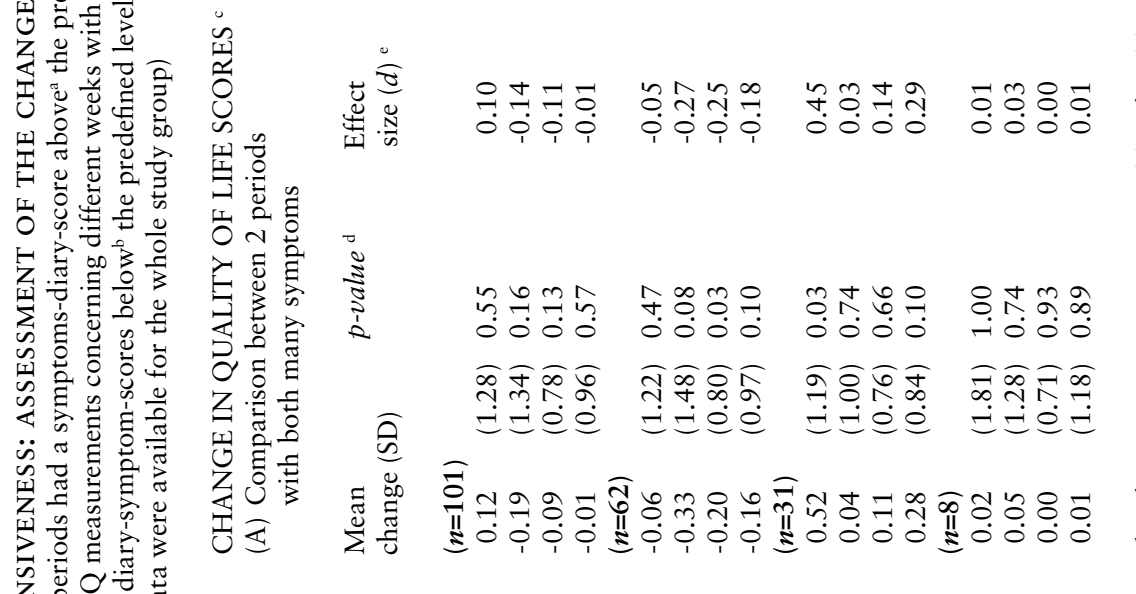

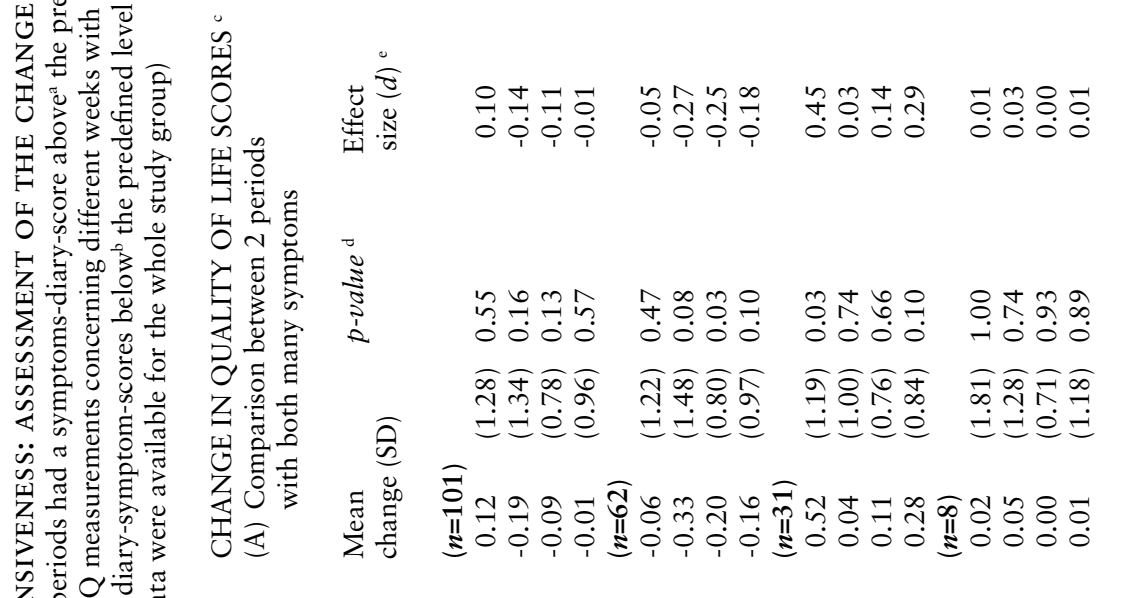

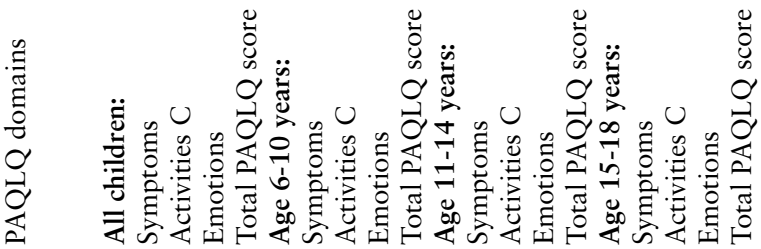

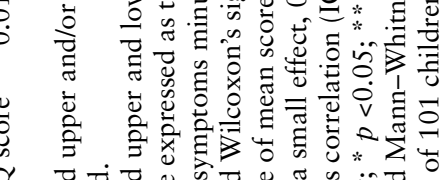

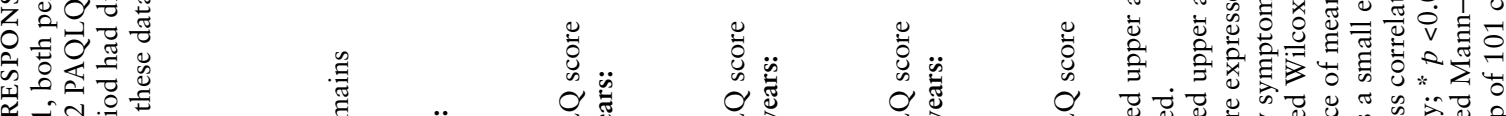
$\dot{n} \approx \vec{\sigma}$

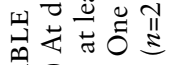

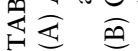

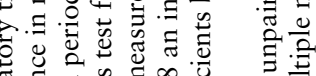

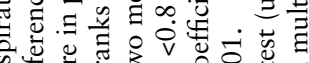

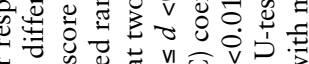
U 政

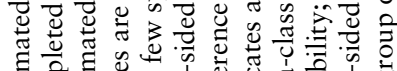

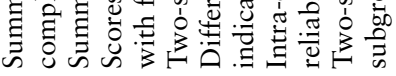



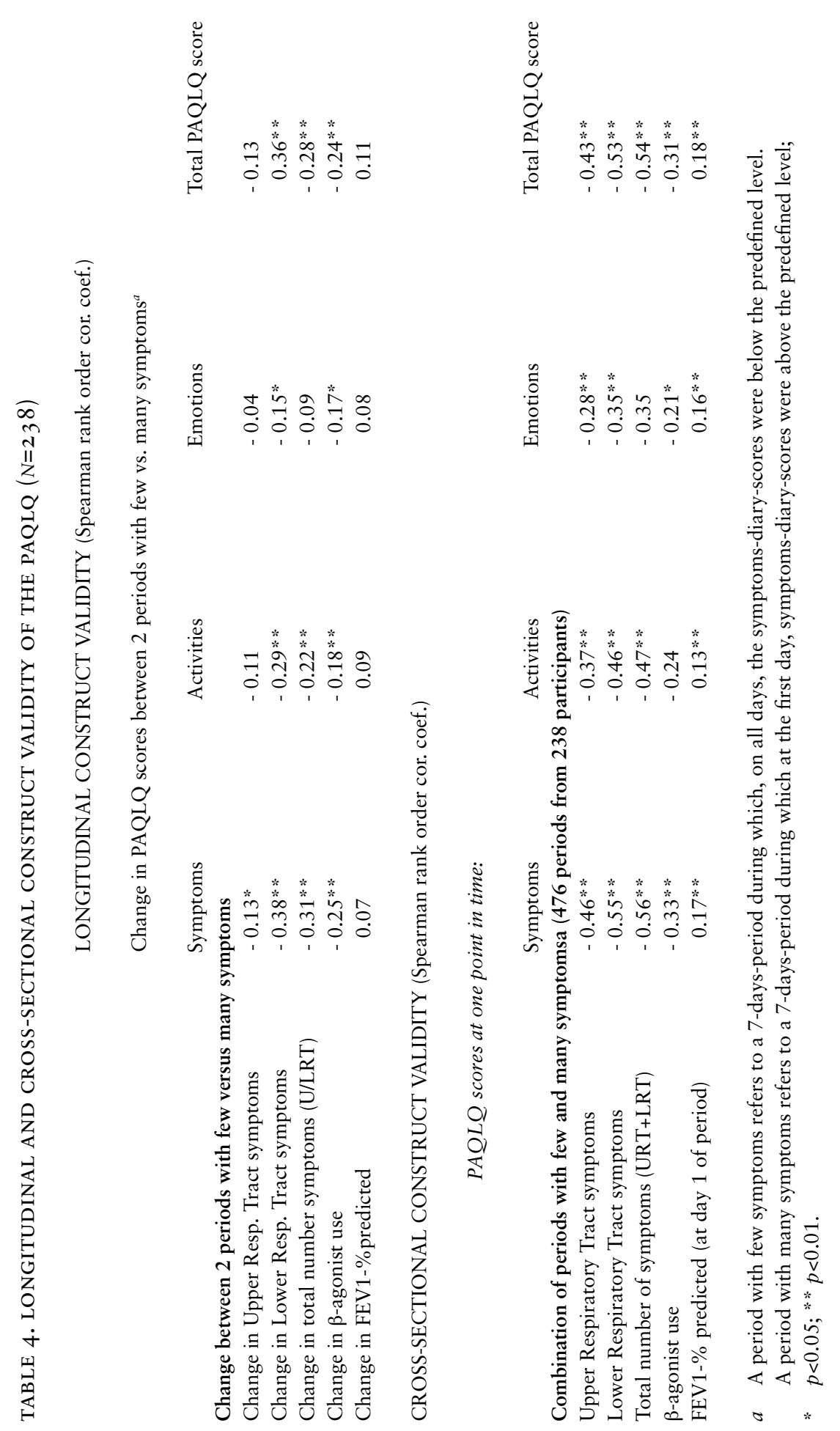


\section{Responsiveness}

The mean change in PAQLQ scores between a period with few and a period with many symptoms was fairly stable across three age groups (total score: 0.79-1.11 points difference) [TABLE 3]. The corresponding effect sizes ranged from 0.801.19 (indicating large effects), except for Emotions (0.40-0.50). PAQLQ-score changes between a period with few and one with many symptoms $(n=238)$ were significantly larger than PAQLQ-score changes between two periods with many symptoms $(n=101)(\mathrm{p}<0.01)$, indicating excellent responsiveness.

\section{Longitudinal and cross-sectional construct validity}

All correlation coefficients assessing construct validity in TABLE 4 were in the expected direction; however, all were either small (defined as $<0.50$ ) or moderate (0.50-0.75). ${ }^{26}$ (Changes in) lower respiratory tract symptoms, indicative of asthma severity, correlated better with (changes in) PAQLQ scores than did (changes in) upper respiratory tract symptoms, which supports the longitudinal and crosssectional construct validity. The symptoms PAQLQ-domain showed the highest correlation coefficients with all indicators, except for $\mathrm{FEV}_{1}-\%$ predicted.

\section{Discussion}

Evaluation of measurement instruments, including cross-cultural validation, is a continuous endeavor requiring studies in diverse clinical populations across countries. ${ }^{20}$ This study, performed in a relatively large sample of children with asthma, supports the cross-cultural validity of the Dutch version of the PAQLQ. It showed psychometric properties and indicators of responsiveness and construct validity of the Dutch PAQLQ that were similar to those originally established for the PAQLQ in Canada ${ }^{3}$ and later in other countries. ${ }^{12-15}$ Limitations of our study include the sample and assessment of test-retest reliability and responsiveness. The study population that was sampled from general practices consisted mainly of moderate cases of asthma; we do not know the results in -sometimes more heterogeneous- hospital-based populations. The evaluation of PAQLQ test-retest reliability was only preliminary, as some of the children may not have been in a stable clinical state during one or both of the two different periods, each with many symptoms, that were evaluated, this may have contributed to the relatively low test-retest ICCs. ${ }^{3}$ In order to evaluate the responsiveness of the PAQLQ, we contrasted PAQLQ mean score differences within pairs of weeks (per child, for 
all children in the study group) where 1 week of the pair had many and the other week had few reported diary-symptoms with, in a subgroup of the same children, the PAQLQ mean score differences within other pairs of weeks (per child in the subgroup) where both weeks within a pair had many reported diary symptoms. In future studies, for the evaluation of responsiveness, we recommend adding other measures of disease stability than the number of reported diary-symptoms. Overall the measurement properties of the Dutch version of the PAQLQ were adequate and there were only two results that gave rise to some concern. (1) The Emotions domain showed ceiling effects, which may, to some degree, limit its use in detecting changes and describing health. (2) The internal consistency of the Activities domain was sub-optimal in our sample (Cronbach's $\alpha<0.70$ ), which may have contributed to the relatively low test-retest ICC in the youngest subgroup; we propose to reevaluate the internal consistency of the Dutch version of the Activities domain in future studies.

This study showed that the Dutch PAQLQ has satisfying psychometric properties, excellent responsiveness, and that longitudinal and cross-sectional construct validity is supported. Issues that require attention are the consequences of the ceiling effects of the domain Emotions, the internal consistency of the domain Activities and the test-retest reliability of the Dutch PAQLQ.

\section{References}

1 Townsend M, Feeny DH, Guyatt GH, et al. Evaluation of the burden of illness for pediatric asthmatic patients and their parents. Ann Allergy 1991; 67: 403-8.

2 Bender BG. Measurement of quality of life in pediatric asthma clinical trials. Ann Allergy Asthma Immunol 1996; 77: 438-45.

3 Juniper EF, Guyatt GH, Feeny DH, et al. Measuring quality of life in children with asthma. Qual Life Res 1996; 5: 35-46.

4 Juniper EF, Guyatt GH, Feeny DH, et al. Measuring quality of life in the parents of children with asthma. Qual Life Res 1996; 5: 27-34.

5 Juniper EF. How important is quality of life in pediatric asthma? Pediatr Pulmonol Suppl 1997; 15: 17-21.

6 Juniper EF. Effect of asthma on quality of life. Can Respir J 1998; 5 Suppl A: 77A-84A.

7 Bukstein DA, McGrath MM, Buchner DA, et al. Evaluation of a short form for measuring health-related quality of life among pediatric asthma patients. J Allergy Clin Immunol 2000; 105: 245-51. 
8 le Coq EM, Colland VT, Boeke AJ, et al. Reproducibility, construct validity, and responsiveness of the "How Are You?" (HAY), a self-report quality of life questionnaire for children with asthma. J Asthma 2000; 37: 43-58.

9 Rutishauser C, Sawyer SM, Bond L, et al. Development and validation of the Adolescent Asthma Quality of Life Questionnaire (AAQOL). Eur Respir J 2001; 17: $52-8$.

10 ISAAC Steering Committee. Worldwide variation in prevalence of symptoms of asthma, allergic rhinoconjunctivitis, and atopic eczema: The International Study of Asthma and Allergies in Childhood (ISAAC). Lancet 1998; 351: 1225-32.

11 Juniper EF, Guyatt GH, Feeny DH, et al. Minimum skills required by children to complete health-related quality of life instruments for asthma: comparison of measurement properties. Eur Respir J 1997; 10: 2285-94.

12 Warschburger P. [Measuring the quality of life of children and adolescents with asthma-The Pediatric Asthma Quality of Life Questionnaire]. Messung der Lebensqualität von asthmaerkrankten Kindern und JugendlichenDer Paediatric Asthma Quality of Life Questionnaire. Rehabilitation (Stuttg) 1998; 37: XVII-XXIII.

13 Clarke E, Sulaiman S, Chew Fook T, et al. Pediatric asthma quality of life questionnaire: validation in children from Singapore. Asian Pac J Allergy Immunol 1999; 17: 155-61.

14 Reichenberg K, Broberg AG. Quality of life in childhood asthma: use of the Paediatric Asthma Quality of Life Questionnaire in a Swedish sample of children 7 to 9 years old. Acta Paediatr 2000; 89: 989-95.

15 Tauler E, Vilagut G, Grau G, et al. The Spanish version of the paediatric asthma quality of life questionnaire (PAQLQ): metric characteristics and equivalence with the original version. Qual Life Res 2001; 10: 81-91.

16 Guillemin F, Bombardier C, Beaton D. Cross-cultural adaptation of health-related quality of life measures: literature review and proposed guidelines. J Clin Epidemiol 1993; 46: 1417-32.

17 Ware JE, Jr., Keller SD, Gandek B, et al. Evaluating translations of health status questionnaires. Methods from the IQOLA project. International Quality of Life Assessment. Int J Technol Assess Health Care 1995; 11: 525-51.

18 Juniper EF. Quality of life questionnaire for children and adolescents with asthma: Dutch version. Hamilton, Ontario, Canada: McMaster University, 1996.

19 Guyatt GH, Kirshner B, Jaeschke R. Measuring health status: what are the necessary measurement properties? J Clin Epidemiol 1992; 45: 1341-5.

20 Anderson RT, Aaronson NK, Bullinger M, McBee WL. A review of the progress towards developing health-related quality-of- life instruments for international clinical studies and outcomes research. Pharmacoeconomics 1996; 10: 336-55. 
21 Bueving HJ, Bernsen RMD, Rimmelzwaan GF, et al. Effectiveness of influenza vaccination in asthmatic children: randomised double blind placebo controlled trial (abstract presented at 12th European Respiratory Society Annual Congress. Stockholm, Sweden, September 14-18, 2002). European Respiratory Journal 2002; 20: $146 s$.

22 Quanjer PH, Borsboom GJ, Brunekreff B, et al. Spirometric reference values for white European children and adolescents: Polgar revisited. Pediatr Pulmonol 1995; 19: 135-42.

23 Raat H, Landgraf JM, Bonsel GJ, et al. Reliability and validity of the child health questionnaire-child form (CHQ-CF87) in a Dutch adolescent population. Qual Life Res 2002; 11(6): 575-581.

24 Bland JM, Altman DG. Cronbach's alpha. BMJ 1997; 314: 572.

25 Deyo RA, Diehr P, Patrick DL. Reproducibility and responsiveness of health status measures. Statistics and strategies for evaluation. Control Clin Trials 1991; 12: 142 S-158S.

26 Cohen J. Statistical power analysis for the behavioral sciences. New York: Academic Press, 1977.

27 Andresen EM, Catlin TK, Wyrwich KW, Jackson-Thompson J. Retest reliability of surveillance questions on health related quality of life. J Epidemiol Community Health 2003; 57: 339-43. 


\section{Chapter 6}

Influenza vaccination in asthmatic children: effects on quality of life and symptoms

European Respiratory Journal 2004; 24: 925-31.

Bueving HJ, van der Wouden JC, Raat H, Bernsen RMD, de Jongste JC, van Suijlekom-Smit LWA, Osterhaus ADME, Rimmelzwaan GF, Rutten-van Mölken MPMH, Thomas S. 


\title{
6. Influenza vaccination in asthmatic children: effects on quality of life and symptoms
}

\begin{abstract}
This study aimed to detect the effect of influenza vaccination on quality of life, symptomatology and spirometry in asthmatic children. We performed a randomised double-blind placebo-controlled trial in 696 (296 in 1999-2000 and 400 in 2000-2001) asthmatic children 6-18 years of age which were vaccinated with either vaccine or placebo. Children participated for only one influenza season. They recorded symptoms in a diary and reported when symptom scores reached a predefined severity level. If so research nurses visited them twice, first to take a pharyngeal swab and spirometry, and a week later to assess quality of life over the past illness week.

Compared to placebo, vaccination improved health-related quality of life in the weeks of illness related to influenza-positive swabs. However, no effect was found for respiratory symptoms recorded in the diaries during those weeks. Similarly, no differences were found for quality of life in all weeks of illness or for respiratory symptoms throughout the seasons.

Our conclusion is that influenza vaccination has a moderate beneficial effect on quality of life in influenza-positive weeks of illness in children with asthma.
\end{abstract}

\section{Introduction}

Influenza vaccination in children with asthma is recommended in most of Europe and North America. ${ }^{1}$ Surprisingly there are no randomised controlled trials confirming that vaccination is beneficial in this group. ${ }^{2}$ We recently reported the results of influenza vaccination in asthmatic children and did not find an effect on the number of influenza-related asthma exacerbations, or on their duration or severity; however, we did find that vaccination shortens the duration of all asthma exacerbations by 0.8 day, irrespective of their cause. ${ }^{3}$

Asthma exacerbations inform us about the status of the pulmonary system but will not capture the functional impairments (physical, emotional, and social) that are important in children's everyday lives. ${ }^{4}$ Apart from preventing exacerbations, 
improvement of the well-being of asthmatic children should also be an important goal of the vaccine treatment. Influenza season has significant adverse effect on the quality of life of school age children and their families. ${ }^{5}$ Influenza vaccine, by inducing a protection against influenza infection and subsequent illness, will reduce systemic and respiratory illness. It also will diminish related morbidity such as missed schooldays, physician visits and the use of medication. This obviously will affect certain domains of quality of life, e.g. symptoms, activity limitations and emotions.

This study reports whether influenza vaccination has an effect on children's asthma-related quality of life during weeks of illness, on respiratory symptoms and on spirometric parameters in the corresponding periods, and on all symptoms throughout the seasons. To verify that the results are not confounded by differences in viral infections between groups, we also report on the viruses that were detected.

\section{Methods}

We conducted a randomised double-blind placebo-controlled parallel trial in children with asthma recruited through general practitioners (GPs) in the city of Rotterdam and its surroundings during two influenza seasons, 1999-2000 and 2000-2001. Here we briefly summarize the design which has been described in detail elsewhere. ${ }^{3}$

\section{Participants}

Children aged 6-18 years were included if they had used maintenance therapy for asthma or more than 52 doses of relief medication during the previous 12 months. Children could participate for only one season. Exclusion criteria were other chronic diseases, allergy to chicken protein and insufficient understanding of the Dutch language. The Medical Ethical Committee of Erasmus MC-University Medical Center Rotterdam approved the study.

\section{Intervention}

In both seasons, research nurses parenterally vaccinated all participants between 25 October and 24 November with either inactivated influenza vaccine or placebo. The vaccine composition for 1999-2000 was a combination of A/Sydney/5/97 H3N2-like, A/Beijing/262/95 H1N1-like and B/Beijing/184/93-like strains and for 2000-2001 A/Moscow/10/99 H3N2-like, A/New Caledonia/20/99 H1N1-like 
and B/Beijing/184/93-like strains as advised by the World Health Organisation. The placebo consisted of a buffered phosphate solution with the same $\mathrm{pH}$ value and was similar in appearance to the inactivated influenza vaccine.

\section{Objectives}

The study aimed to answer whether influenza vaccination in children with asthma has an effect on asthma-related quality of life, respiratory symptoms and spirometric parameters during weeks of illness and on their symptomatology throughout the influenza season.

\section{Quality of life}

Health related quality of life was assessed by means of the Dutch version of the 23-item Pediatric Asthma Quality of Life Questionnaire (PAQLQ), which we recently validated. ${ }^{6,7}$ The PAQLQ consists of the domains symptoms (10 items), activities (5 items) and emotions ( 8 items). The instrument measures well-being over a previous period of 7 days, a period which covers the usual period of symptoms and signs typically due to influenza. The score for every item ranges from 1-7, with higher scores indicating a better quality of life.

When children reached the threshold of the severity level for symptoms a PAQLQ was administered one week later. In case of multiple weeks of illness we calculated the mean PAQLQ values. For all children, a baseline PAQLQ was administered when upper respiratory tract infection (URT) and lower respiratory tract infection (LRT) symptom scores had been beneath the threshold of 4 points for a period of at least seven days. We considered a change between the total scores or domain scores of baseline versus illness of at least 0.5 points as a minimal important difference (MID). The clinical relevance of this difference was assessed previously. ${ }^{6}$

\section{Symptom scores and weeks of illness}

Participants (or their parents) were asked to fill in a diary, starting the day after vaccination, and daily score symptoms of URT and LRT. URT symptoms included sneezing, runny or stuffy nose, burning or watery eyes, sore throat, hoarseness, fever or shivering, headache and myalgia. LRT symptoms (asthma symptoms) included cough and wheeze during day and night and difficult breathing or shortness of breath. If present, respiratory tract symptoms were scored from one (mild) to three (severe) and summed; not fit to go to school or work because 
of symptoms was scored as two. We instructed participants to telephone the investigators when the summated scores for either URT or LRT symptoms totalled four or more on a given day. As soon as possible, but within 48 hours after the call, a research nurse visited the child, took a throat swab for the detection of viruses and performed spirometry. This procedure was adopted from Johnston et al. ${ }^{8}$ One week later, nurses administered a PAQLQ. We defined these weeks, starting with a predefined severity level for respiratory symptoms as "weeks of illness".

\section{Spirometry}

A handheld spirometer (Micro DL Micro Medical Systems UK) was used, standardised in accordance with the recommendations of the American Thoracic Society, and measured forced expiratory volume in one second $\left(\mathrm{FEV}_{1}\right)$, forced vital capacity (FVC), and maximum expiratory flow at $25 \%$ of FVC $\left(\mathrm{MEF}_{25}\right)$ and maximum expiratory flow at $50 \%$ of $\mathrm{FVC}\left(\mathrm{MEF}_{50}\right)$. On each occasion spirometry was performed three times and the best result was taken. We obtained spirometric data at inclusion, at the same moment as the baseline PAQLQ, and at the start of a week of illness. When children had multiple weeks of illness the mean spirometric values were calculated. Values for $\mathrm{FEV}_{1}$ and FVC were expressed as percentage of predicted values according to age, gender and height following the procedure proposed by Quanjer et al. ${ }^{9}$ and for $\mathrm{MEF}_{25}$ and $\mathrm{MEF}_{50}$ as proposed by Rosenthal et al. ${ }^{10}$

\section{Virological assessments}

Throat swabs were cultured and searched for the presence of influenza virus $\mathrm{A}$ and $\mathrm{B}$ as described earlier ${ }^{3}$ and the same method was applied for detecting parainfluenza 1, 2 and 3, adenovirus and respiratory syncytial virus. Subsequently they were analyzed by immunofluorescence for respiratory viruses using specific reagents (Dako, Glostrup, Denmark). Throat swabs were also tested by polymerase chain reaction (PCR) for influenza $\mathrm{A}$ and $\mathrm{B}^{11}$ and rhinoviruses. ${ }^{12}$

\section{Randomisation and blinding}

Randomisation, packing and labelling took place by the manufacturer of the vaccine. All those involved, i.e. patients and parents, general practitioners and investigators, were blinded. 


\section{Statistical methods}

We analysed the data by intention to treat. Differences between groups were analysed by Fisher's exact test in case of proportions and by analysis of variance for continuous data.

\section{Results}

A total of 200 GPs in 144 practices participated. GPs selected 3220 children and informed them and their parents by letter about the objectives of our study. In total, 1365 children were willing to participate. After inclusion and informed consent, 696 children participated. Of these, 347 were vaccinated with influenza vaccine and 349 with placebo. In each group 344 participants provided diary data. We have already described this trial profile in detail. ${ }^{3}$ In the two seasons the study was conducted (1999-2000 and 2000-2001), the influenza vaccine strains matched well with epidemic virus strains. ${ }^{13,14}$

\section{Characteristics at inclusion and at baseline}

The groups were similar for characteristics at inclusion and baseline except for history of allergy [TABLE I]. Of all children, $55 \%$ had been vaccinated against influenza before.

\section{Outcomes}

\section{Weeks of illness}

We received 486 telephone calls reporting a score of 4 points or more concerning 347 children of which 178 children were in the vaccine group and 169 children were in the placebo group. In the vaccine group 117 children reported once, 40 twice, nine three, two four and one five time(s). In the placebo group 123 children reported once, 43 twice, nine three, two four and one five time(s). For 342 of these 347 children one or more outcomes during weeks of illness were available, 176 in the vaccine group and 166 in the placebo group. There were 43 weeks of illness in which influenza virus was detected (one double infection with influenza A and B), 22 in the vaccine group and 21 in the placebo group. Of those influenza-positive weeks, data on quality of life were available in 40 
cases and on symptoms and spirometry in 42 cases.

TABLE I. BASELINE CHARACTERISTICS OF THE STUDY POPULATION $(n=696)$

At inclusion visits

vaccine placebo

mean (SD) unless otherwise stated

age in years, mean (SD)

$n=347$

$n=349$

female gender

$10.5(3.2) \quad 10.6(3.3)$

age of onset of asthma in years, mean (SD)

$48.1 \%$

$43.6 \%$

ever vaccinated for influenza

$3.5(3.8)$

$3.3(3.4)$

$53.6 \%$

$56.7 \%$

history of allergy

$73.5 \%$

$66.1 \%$

child born in the Netherlands

$97.7 \%$

$98.9 \%$

$\mathrm{FEV}_{1}-\%$ predicted, mean $(\mathrm{SD})$

$89.5(16.1) \quad 88.9(16.0)$

At baseline visits

quality of life *(values are mean symptom scores)

$n=331$

$n=331$

total score

6.16

6.16

activities

5.60

5.60

emotions

6.63

6.63

symptoms

6.05

6.05

spirometry (mean (SD))

$n=332$

$n=337$

mean $\mathrm{FEV}_{1}$

2.13(.76)

2.13(.80)

$\%$ predicted

93(14)

92(13)

mean FVC

2.43(.88)

2.43(.96)

$\%$ predicted

92(14)

90(14)

mean $\mathrm{MEF}_{50}$

2.68(1.10)

2.66(1.0)

$\%$ predicted

$90(25)$

$90(24)$

mean $\mathrm{MEF}_{25}$

1.42(.71)

1.42(.67)

$\%$ predicted

94(36)

96(36)

* Scores range from 1-7, with higher scores indicating a better quality of life.

Quality of life

A baseline PAQLQ was obtained from 662 children, 331 in the placebo group and 331 in the vaccine group. For all children baseline scores both for the total score and the domain scores did not differ between the groups.

In 333 children a PAQLQ for a baseline week and a PAQLQ during one or more illness weeks was recorded. In children who reported weeks of illness no differences in baseline were found between the vaccine group and the placebo 
group.

Differences between baseline PAQLQ scores and scores during influenza positive weeks of illness favoured the vaccine group, as did differences in the symptoms and activities domains [TABLE 2], whilst there were no differences between baseline scores and scores in weeks of illness irrespective of their cause. The proportion of children reaching the minimal important difference for the symptoms domain in influenza-positive weeks as well as in all weeks of illness were both significantly lowered in the vaccine group [TABLE 2].

TABLE 2. MEAN QUALITY OF LIFE ASSESSED BY THE PEDIATRIC ASTHMA QUALITY OF LIFE QUESTIONNAIRE (PAQLQ)

\begin{tabular}{|c|c|c|c|c|c|c|}
\hline \multirow[t]{2}{*}{ Qol scores* } & vaccine & placebo & p-value & vaccine & placeb & p-valu \\
\hline & $n=173$ & $n=160$ & & $n=21$ & $n=19$ & \\
\hline mean baseline & \multicolumn{2}{|c|}{ all weeks of illness } & \multicolumn{4}{|c|}{ influenza-positive weeks } \\
\hline total & 5.54 & 5.43 & 0.35 & 5.87 & 5.47 & 0.15 \\
\hline activities & 4.85 & 4.73 & 0.38 & 5.23 & 4.82 & 0.27 \\
\hline emotions & 6.30 & 6.26 & 0.28 & 6.47 & 6.38 & 0.75 \\
\hline symptoms & 5.24 & 5.10 & 0.72 & 5.69 & 5.03 & 0.08 \\
\hline mean differences $* *$ & \multicolumn{3}{|c|}{$\begin{array}{l}\text { between baseline and } \\
\text { all weeks of illness }\end{array}$} & \multicolumn{3}{|c|}{$\begin{array}{l}\text { between baseline and } \\
\text { influenza-positive weeks }\end{array}$} \\
\hline total score & -0.65 & -0.76 & 0.19 & -0.40 & -1.00 & 0.02 \\
\hline activities & -0.82 & -1.00 & 0.14 & -0.49 & -1.31 & 0.02 \\
\hline emotions & -0.35 & -0.40 & 0.56 & -0.21 & -0.41 & 0.29 \\
\hline symptoms & -0.81 & -0.95 & 0.20 & -0.52 & -1.35 & 0.04 \\
\hline MID $* * *$ & \multicolumn{3}{|c|}{$\begin{array}{l}\text { between baseline and } \\
\text { all weeks of illness }\end{array}$} & \multicolumn{3}{|c|}{$\begin{array}{l}\text { between baseline and } \\
\text { influenza-positive weeks }\end{array}$} \\
\hline total score & $50 \%$ & $61 \%$ & 0.06 & $48 \%$ & $68 \%$ & 0.22 \\
\hline activities & $54 \%$ & $64 \%$ & 0.06 & $48 \%$ & $79 \%$ & 0.06 \\
\hline emotions & $27 \%$ & $26 \%$ & 1.00 & $24 \%$ & $26 \%$ & 1.00 \\
\hline symptoms & $52 \%$ & $65 \%$ & 0.01 & $43 \%$ & $79 \%$ & 0.03 \\
\hline
\end{tabular}

\footnotetext{
* Scores range from 1-7, with higher scores indicating better quality of life.

** Negative differences, indicating a poorer quality of life during weeks of illness.

$\because * *$ Proportion of patients with a negative difference of 0.5 points or more MID; minimal important difference.
} 
No differences were found between study arms for mean total or separate URT or LRT symptom scores and for symptom scores in influenza-related weeks or all weeks of illness irrespective of cause [TABLE 3].

TABLE 3. MEAN RESPIRATORY TRACT SYMPTOM SCORES PER DAY IN CHILDREN DURING WEEKS OF ILLNESS

Mean upper respiratory tract (URT) symptom scores*

\begin{tabular}{|c|c|c|c|c|c|}
\hline \multicolumn{3}{|c|}{ All weeks of illness } & \multicolumn{3}{|c|}{ Influenza-positive weeks } \\
\hline vaccine & placebo & p-value & vaccine & placebo & p-value \\
\hline$n=176$ & $n=166$ & & $n=22$ & $n=20$ & \\
\hline
\end{tabular}

$\begin{array}{lllllll}\text { runny or stuffy nose } & 0.91 & 0.85 & 0.43 & 0.97 & 0.85 & 0.60 \\ \text { sneezing } & 0.33 & 0.29 & 0.44 & 0.44 & 0.38 & 0.60 \\ \text { burning or watery eyes } & 0.13 & 0.15 & 0.74 & 0.26 & 0.20 & 0.68 \\ \text { sore throat } & 0.38 & 0.35 & 0.52 & 0.32 & 0.45 & 0.24 \\ \text { hoarseness } & 0.12 & 0.12 & 0.98 & 0.06 & 0.15 & 0.21 \\ \text { fever or shivering } & 0.22 & 0.21 & 0.86 & 0.41 & 0.43 & 0.82 \\ \text { headache } & 0.39 & 0.33 & 0.30 & 0.37 & 0.54 & 0.27 \\ \text { myalgia } & 0.07 & 0.07 & 0.89 & 0.07 & 0.10 & 0.67 \\ \text { total URT symptom score } & 2.56 & 2.37 & 0.37 & 2.91 & 3.13 & 0.69\end{array}$

Mean lower respiratory tract (LRT) symptom scores*

\begin{tabular}{|c|c|c|c|c|c|c|}
\hline cough during the day & 0.93 & 1.03 & 0.26 & 1.05 & 1.27 & 0.39 \\
\hline cough during the night & 0.50 & 0.52 & 0.78 & 0.67 & 0.71 & 0.86 \\
\hline wheeze during the day & 0.13 & 0.16 & 0.50 & 0.15 & 0.18 & 0.77 \\
\hline wheeze during the night & 0.10 & 0.11 & 0.58 & 0.07 & 0.11 & 0.50 \\
\hline \multicolumn{7}{|l|}{ difficult breathing or } \\
\hline shortness of breath & 0.39 & 0.42 & 0.56 & 0.32 & 0.64 & 0.06 \\
\hline total LRT symptom score & 2.05 & 2.24 & 0.33 & 2.25 & 2.91 & 0.24 \\
\hline
\end{tabular}

* Every separate score reached from 0 (absent) to 3 (severe). 


\section{Spirometry}

At inclusion, we acquired spirometric data of 682 children [TABLE I] and at baseline spirometric data of 669 children, 332 in the vaccine group and 337 in the placebo group [TABLE I]. Both baseline spirometry and spirometry during the weeks of illness were available for 455 of the 486 weeks of illness; in the remaining 31 cases either one or both spirometric values were not available due to technical problems. No differences were found between vaccine and placebo for baseline spirometric values [TABLE I]. At the onset of influenza-positive periods we found a significant difference in FVC percentage predicted favouring the vaccine group [TABLE 4], with a non-significant trend for improvement of $\mathrm{FEV}_{1}$.

TABLE 4. DATA ON SPIROMETRIC PARAMETERS

\begin{tabular}{|c|c|c|c|c|c|c|}
\hline mean values & vaccine & placebo & p-value & vaccine & placebo & p-value \\
\hline & $n=172$ & $n=157$ & & $n=21$ & $n=20$ & \\
\hline values are mean (SD) & all weeks o & of illness & influenza & ositive week & & \\
\hline $\mathrm{FEV}_{1}$ & $1.95(.75)$ & $2.00(.86)$ & 0.63 & $1.77(.82)$ & $1.59(.67)$ & 0.31 \\
\hline$\%$ predicted & $87(17)$ & $85(17)$ & 0.24 & $89(22)$ & $80(20)$ & 0.09 \\
\hline FVC & $2.25(.85)$ & $2.31(1.02)$ & 0.60 & $2.06(.52)$ & $1.92(.82)$ & 0.53 \\
\hline$\%$ predicted & $87(16)$ & $85(17)$ & 0.14 & $91(18)$ & $80(19)$ & 0.08 \\
\hline $\mathrm{MEF}_{50}$ & $2.36(1.0)$ & $2.38(1.0)$ & 0.87 & $2.08(.50)$ & $1.83(1.0)$ & 0.32 \\
\hline$\%$ predicted & $81(25)$ & $79(24)$ & 0.69 & $78(17)$ & $75(29)$ & 0.66 \\
\hline $\mathrm{MEF}_{25}$ & $1.29(.64)$ & $1.33(.71)$ & 0.56 & $1.11(.28)$ & $0.98(.56)$ & 0.35 \\
\hline$\%$ predicted & $88(36)$ & $88(35)$ & 0.86 & $83(21)$ & $82(33)$ & 0.92 \\
\hline differences* & vaccine & placebo & p-value & vaccine & placebo & p-value \\
\hline & $n=162$ & $n=153$ & & $n=21$ & $n=20$ & \\
\hline $\mathrm{FEV}_{1}$ & $-7(13)$ & $-8(12)$ & 0.31 & $-4(12)$ & $-12(11)$ & .06 \\
\hline FVC & $-5(14)$ & $-6(14)$ & 0.34 & $-0(12)$ & $-11(15)$ & .01 \\
\hline MEF50 & $-10(16)$ & $-11(20)$ & 0.59 & $-11(15)$ & $-17(15)$ & .17 \\
\hline MEF25 & $-8(29)$ & $-10(30)$ & 0.37 & $-13(22)$ & $-13(19)$ & .88 \\
\hline
\end{tabular}

* Differences in \% predicted comparing spirometry at baseline and during illness weeks 
No differences were found for mean total daily scores on URT and LRT symptoms throughout the influenza season between the vaccine group and the placebo group [TABLE 5] or for the number of days not fit to go to school or work because of those symptoms.

TABLE 5. MEAN RESPIRATORY TRACT SYMPTOM SCORES PER DAY THROUGHOUT

THE INFLUENZA SEASON

$$
\begin{aligned}
& \text { vaccine placebo } \\
& n=344 \quad n=344 \\
& \text { mean symptom score* } \quad p \text {-value }
\end{aligned}
$$

Upper respiratory tract (URT)

$\begin{array}{llll}\text { runny or stuffy nose } & 0.30 & 0.26 & 0.11 \\ \text { sneezing } & 0.12 & 0.10 & 0.29 \\ \text { burning or watery eyes } & 0.04 & 0.03 & 0.73 \\ \text { sore throat } & 0.07 & 0.06 & 0.10 \\ \text { hoarseness } & 0.03 & 0.03 & 0.64 \\ \text { fever or shivering } & 0.03 & 0.03 & 0.85 \\ \text { headache } & 0.10 & 0.09 & 0.41 \\ \text { myalgia } & 0.04 & 0.02 & 0.08 \\ \text { total URT symptom score } & 0.75 & 0.65 & 0.13\end{array}$

Lower respiratory tract (LRT)

cough during the day

$0.25 \quad 0.23 \quad 0.61$

cough during the night

$\begin{array}{lll}0.11 & 0.11 \quad 0.98\end{array}$

wheeze during the day

$\begin{array}{lll}0.04 & 0.04 & 0.85\end{array}$

wheeze during the night

$\begin{array}{lll}0.03 & 0.04 & 0.39\end{array}$

difficult breathing or shortness of breath

$\begin{array}{lll}0.13 & 0.14 & 0.90\end{array}$

total LRT symptom score

$0.58 \quad 0.58$

1.00

* Each separate score ranged from 0 (absent) to 3 (severe).

\section{Detection of viruses}

In 484 of 486 weeks of illness a throat swab was taken, one child on two occasions did not allow a throat swab to be taken. We detected viruses in $136(28.1 \%)$ of 484 throat swabs (4 double infections), 41 times influenza A (8.5\%), 3 times 
influenza B (0.6\%), 14 times corona (2.9\%), 57 times rhinovirus $(11.8 \%), 12$ times respiratory syncytial virus $(2.5 \%)$ and 9 times miscellaneous viruses $(1.9 \%)$ [TABLE 6]. Detection rates were $37 \%$ for the vaccine group and $34 \%$ for the placebo group for $1999-2000$, and $19 \%$ vs. $26 \%$ for $2000-2001$, respectively. There were no significant differences in total detection rates or for separate viruses between the vaccine group and the placebo group.

TABLE 6. PATHOGENS DETECTED BY EITHER CULTURE, IMMUNOFLUORESCENCE OR PCR IN THROAT SWABS IN REPORTED PERIODS

$\begin{array}{lccccc}n=486 \text { calls } & \text { Placebo } & \text { Vaccine } & \text { Placebo } & \text { Vaccine } & \text { Total } \\ \text { influenza H3N2 } & 1999-2000 & 1999-2000 & 2000-2001 & 2000-2001 & \\ \text { influenza H1N1 } & 6 & 2 & 0 & 0 & 8 \\ \text { influenza B } & 0 & 0 & 13 & 20 & 33 \\ \text { rhinovirus } & 0 & 0 & 2 & 1 & 3 \\ \text { coronavirus } & 20 & 24 & 5 & 8 & 57 \\ \text { RSV } & 9 & 2 & 0 & 3 & 14 \\ \text { adenovirus } & 4 & 7 & 0 & 1 & 12 \\ \text { miscellaneous } & 1 & 0 & 1 & 2 & 4 \\ \text { no virus found } & 3 & 2 & 3 & 1 & 9 \\ \text { number of reported periods } & 70 & 74 & 101 & 103 & 348 \\ \text { num } & 111 & 112 & 124 & 139 & 486^{\mathrm{a}}\end{array}$

${ }^{a}$ Column does not add up to 486 because of four double infections and two absent throat swabs.

RSV: respiratory syncytial virus

\section{Discussion}

We found that influenza vaccination, compared to placebo, improved healthrelated quality of life in asthmatic children in the weeks of illness in which influenza virus was detected in their throat swabs. This improvement was found for overall asthma-related quality of life as measured by the PAQLQ as well as for its symptoms and activities domains. The findings for the symptoms domain concur with the findings using the minimal important difference as an additional parameter, relevant for clinical practice. In illness weeks we also found a difference in FVC as percentage predicted favouring the vaccine group. However, in influenzapositive weeks of illness no differences were found between the vaccine group and the placebo group for mean URT or LRT symptoms. Regarding all weeks of illness irrespective of their cause, no differences were found for mean URT 
or LRT symptoms or for spirometric parameters. With regard to respiratory symptoms throughout the seasons, influenza vaccination did not reduce URT and LRT symptoms in asthmatic children.

That influenza vaccination in this analysis improves asthma related quality of life in weeks of illness is in contrast to our previous findings on influenza-related asthma exacerbations. Our earlier analysis showed no difference in the number, duration and severity of influenza-related asthma exacerbations as a result of vaccination. ${ }^{3}$

How can this discrepancy be explained? First, in our previous paper we defined exacerbations as episodes of LRT symptoms of 2 or more days with symptom scores above the median for that child preceded by at least 1 day at or below the median and followed by at least 2 days at or below the median. In this way less severe and supplemental symptomatology may have been ignored and hence a possible effect might have escaped attention. Secondly, the duration of the exacerbations may not exactly cover the weeks of illness in which we measured quality of life. Thirdly, the sensitivity of the PAQLQ for vaccine-related benefits may be higher than the diary symptom score list we used. ${ }^{8}$ This might well be the case, as questions on well-being, the use of more domains for measuring asthma, the greater scale range of the scores and the way of conducting the questionnaires by research nurses may detect changes that our simpler diary cards could not pick up.

Our findings of no difference in the number of days with symptoms and the mean severity of symptoms throughout the seasons between study arms seem contradictory to the results of our first study that vaccination reduced the length of all asthma exacerbations, irrespective of their cause. A possible explanation is that the use of a threshold symptom score before telephoning, may have led to an under-detection of influenza and influenza related asthma exacerbations. However, when we consider all days with symptoms throughout the seasons, instead of restricting it to asthma exacerbations, differences disappear.

In our study baseline scores of the PAQLQ were relatively high, implying a better quality of life compared to other studies; ${ }^{15-17}$ these latter studies were, however performed in hospital-based populations. Children in our study probably had less severe asthma, because they were recruited via the GP. We found that weeks of illness were characterised by a reduction in the total PAQLQ score of 0.65 in the vaccine group and 0.76 in the placebo group, as compared to baseline. This reduction compares well with the decrease in symptoms of 0.65 points in children with mild and severe asthmatic episodes, which has been reported before. ${ }^{15}$ In the present study, compared with placebo, influenza vaccination improved the 
total score on quality of life in influenza-positive periods by 0.6 points, which may be a meaningful improvement when considering the threshold for clinical relevance of 0.5 points for the MID. Other studies, also using the PAQLQ, found pre- and post-treatment improvements in total scores of $0.69^{16}$ and $0.25^{17}$ points. The PAQLQ has been reported to correlate with symptom scores and degree of asthma. ${ }^{15,18,19}$

With regard to spirometry we found a lower FVC in influenza-positive periods in the placebo group compared to the vaccine group. The fall in FVC could be a result of influenza infection, but may have been caused by inadequate spirometry performance of the children whilst being ill. This is supported by the fact that no difference was found on other spirometric indices. In weeks of illness irrespective of their cause, no significant differences were found between study arms in percentage of change in spirometry parameters, as an indicator of relevant airway obstruction in asthma.

Using throat swabs, we detected viruses in $28.7 \%$ of the weeks of illness. Considering the viruses detected it is unlikely that an imbalanced distribution of viral infections confounded our results. Lower ${ }^{20,21}$ as well as higher ${ }^{8,22}$ rates of detection have been reported in asthmatic children. The differences in detection rate between studies can be explained by differences in sample techniques, laboratory techniques, time frames used and natural fluctuations in the viruses that cause infection.

Rhinovirus played the most important role in all these studies ${ }^{8,20-22}$ and were found in respectively $42 \%, 46 \%, 65 \%$, and $66 \%$ of cases. In our study, rhinovirus was found in $41 \%$ of positive swabs. The incidence of influenza A and B varies with year and place. Of the 696 children in our study, 43(8.9\%) had influenza detected by culture or PCR. In the above-mentioned studies ${ }^{8,20-22}$ influenza was detected in respectively $1 \%, 6.7 \%, 7.4 \%$ and $19.4 \%$ of participating children. In a recent study, Tsai et al. ${ }^{23}$ examined the relationship between clinical symptoms and respiratory infection using conventional laboratory methods in paediatric outpatients during three years $(1997,1998,1999)$. In $35 \%$ of these cases one or more viruses were detected; influenza $\mathrm{A}$ was isolated in $5.5 \%$ and $\mathrm{B}$ in $2.6 \%$ of cases with acute respiratory tract conditions. In our study only small differences in the number and type of viral infections between vaccine group and placebo group were found.

What is the clinical relevance of the present findings? Vaccination rates in children with asthma are reported to be very low. ${ }^{24,25}$ One of the reasons why physicians do not recommend influenza vaccination is disbelief in the positive effects of vaccination. ${ }^{26}$ Among patients, reasons not to obtain influenza vaccination are 
doubts about the efficacy of influenza vaccine, fear of possible side-effects, and non-recommendation by their doctor. ${ }^{27,28}$ As far as we know this is the first randomised placebo-controlled study to demonstrate beneficial effects of influenza vaccination in children with asthma. In our study influenza vaccination, compared with placebo, was associated with a relevant improvement in the quality of life of asthmatic children in the weeks of illness in which influenza virus was detected. However, our study had relatively low influenza-positive weeks of illness and could not detect any favourable effect of influenza vaccination on influenza-related asthma exacerbations and respiratory symptoms throughout the season. Hence, the question remains whether or not it is worth the effort to promote vaccination of all asthmatic children aged 6-18 years in general practice.

Therefore, to justify routine influenza vaccination in asthmatic children, we strongly recommend that further randomised placebo-controlled trials be carried out to assess the clinical effectiveness as well as the cost-effectiveness of influenza vaccination in children with asthma.

\section{References}

1 Nicholson KG, Snacken R, Palache AM. Influenza immunization policies in Europe and the United States. Vaccine 1995; 13: 365-9.

2 Cates CJ, Jefferson TO, Bara AI, Rowe BH. Vaccines for preventing influenza in people with asthma (Cochrane Review): Oxford: Update Software, 2002.

3 Bueving HJ, Bernsen RM, De Jongste JC, et al. Influenza vaccination in children with asthma: randomized double-blind placebo-controlled trial. Am J Respir Crit Care Med 2004; 169: 488-93.

4 Juniper EF. How important is quality of life in pediatric asthma? Pediatr Pulmonol Suppl 1997; 15: 17-21.

5 Neuzil KM, Hohlbein C, Zhu Y. Illness among schoolchildren during influenza season: effect on school absenteeism, parental absenteeism from work, and secondary illness in families. Arch Pediatr Adolesc Med 2002; 156: 986-91.

6 Juniper EF, Guyatt GH, Feeny DH, et al. Measuring quality of life in children with asthma. Qual Life Res 1996; 5: 35-46.

7 Raat H, Bueving HJ, De Jongste JC, et al. Responsiveness, longitudinal- and cross sectional construct validity of the Pediatric Asthma Quality of Life Questionnaire (PAQLQ) in Dutch children with asthma. Qual Life Res 2005; 14: 265-272. 
8 Johnston SL, Pattemore PK, Sanderson G, et al. Community study of role of viral infections in exacerbations of asthma in 9-11 year old children. BMJ 1995; 310: 1225-9.

9 Quanjer PH, Borsboom GJ, Brunekreef B, et al. Spirometric reference values for white European children and adolescents: Polgar revisited. Pediatr Pulmonol 1995; 19: $135-42$.

10 Rosenthal M, Bain SH, Cramer D, et al. Lung function in white children aged 4 to 19 years: I--Spirometry. Thorax 1993; 48: 794-802.

11 Fouchier RA, Bestebroer TM, Herfst S, et al. Detection of influenza A viruses from different species by PCR amplification of conserved sequences in the matrix gene. J Clin Microbiol 2000; 38: 4096-101.

12 Pitkaranta A, Arruda E, Malmberg H, Hayden FG. Detection of rhinovirus in sinus brushings of patients with acute community-acquired sinusitis by reverse transcription-PCR. J Clin Microbiol 1997; 35: 1791-3.

13 Nationaal Influenza Centrum (NIC): Rotterdam; Rijksinstituut voor Volksgezondheid en Milieu (RIVM): Bilthoven; Nederlands instituut voor onderzoek van de gezondsheidszorg (NIVEL); Inspectie voor de gezondheidszorg (IGZ). Nieuwsbrief influenza-surveillance 1999/2000; 8(Pt 8).

14 Nationaal Influenza Centrum (NIC): Rotterdam; Rijksinstituut voor Volksgezondheid en Milieu (RIVM): Bilthoven; Nederlands instituut voor onderzoek van de gezondsheidszorg (NIVEL); Inspectie voor de gezondheidszorg (IGZ). Nieuwsbrief influenza-surveillance 2000/01; 9(Pt 5).

15 Reichenberg K, Broberg AG. Quality of life in childhood asthma: use of the Paediatric Asthma Quality of Life Questionnaire in a Swedish sample of children 7 to 9 years old. Acta Paediatr 2000; 89: 989-95.

16 Knorr B, Matz J, Bernstein JA, et al. Montelukast for chronic asthma in 6- to 14-yearold children: a randomized, double-blind trial. Pediatric Montelukast Study Group. Jama 1998; 279: 1181-6.

17 Lemanske RF, Jr., Nayak A, McAlary M, et al. Omalizumab improves asthma-related quality of life in children with allergic asthma. Pediatrics 2002; 110: e55.

18 Tauler E, Vilagut G, Grau G, et al. The Spanish version of the paediatric asthma quality of life questionnaire (PAQLQ): metric characteristics and equivalence with the original version. Qual Life Res 2001; 10: 81-91.

19 Clarke E, Sulaiman S, Chew Fook T, et al. Pediatric asthma quality of life questionnaire: validation in children from Singapore. Asian Pac J Allergy Immunol 1999; 17: 155-61.

20 Mitchell I, Inglis JM, Simpson H. Viral infection as a precipitant of wheeze in children. Combined home and hospital study. Arch Dis Child 1978; 53: 106-11. 
21 Horn ME, Brain EA, Gregg I, et al. Respiratory viral infection and wheezy bronchitis in childhood. Thorax 1979; 34: 23-8.

22 Mertsola J, Ziegler T, Ruuskanen O, et al. Recurrent wheezy bronchitis and viral respiratory infections. Arch Dis Child 1991; 66: 124-9.

23 Tsai HP, Kuo PH, Liu CC, Wang JR. Respiratory viral infections among pediatric inpatients and outpatients in Taiwan from 1997 to 1999. J Clin Microbiol 2001; 39: 111-8.

24 Szilagyi PG, Rodewald LE. Missed opportunities for influenza vaccination among children with asthma. Pediatr Infect Dis J 1992; 11: 705-8.

25 Kramarz P, DeStefano F, Gargiullo PM, et al. Influenza vaccination in children with asthma in health maintenance organizations. Vaccine Safety Datalink Team. Vaccine 2000; 18: 2288-94.

26 Nichol KL, Zimmerman R. Generalist and subspecialist physicians' knowledge, attitudes, and practices regarding influenza and pneumococcal vaccinations for elderly and other high-risk patients: a nationwide survey. Arch Intern Med 2001; 161: 2702-8.

27 Nichol KL, Mac Donald R, Hauge M. Factors associated with influenza and pneumococcal vaccination behavior among high-risk adults. J Gen Intern Med 1996; 11: 673-7.

28 Fiebach NH, Viscoli CM. Patient acceptance of influenza vaccination. Am J Med 1991; 91: 393-400. 
Chapter 7

General discussion 


\section{General discussion}

The studies reported in this thesis were performed to collect the best available evidence for the burden of disease from influenza in children and to reliably assess the effectiveness of influenza vaccination in children with asthma.

To gain overview of the burden of disease due to influenza in children we performed a systematic review on the incidence of influenza and its related illness [CHAPTER 2].

To provide direct evidence for the protective effectiveness and adverse effects of influenza vaccination in children with asthma we performed a double blind placebo-controlled trial into the effectiveness of influenza vaccination on asthma symptoms [CHAPTER $3,4,5,6]$.

\section{Current state of affairs and questions to be asked}

Asthma is nowadays seen as a disease of chronic inflammation of varying degrees of severity instead of solely a disease of reversible airway obstruction. Treatment has progressed along with the growing knowledge of the underlying pathophysiological mechanisms. ${ }^{1}$ With adequate treatment, consisting of a combination of maintenance and rescue medication, patients nowadays can lead a normal life and suppress the asthmatic symptoms following common airway infections. ${ }^{2}$ This treatment is at direct disposal of patients and their caretakers and there is no indication that its efficacy is influenced by the antigenic characteristics of the influenza virus.

In children, asthma is in absolute and relative numbers the most important chronic disease. The reason to vaccinate asthmatic children against influenza is the prevention of exacerbations of upper respiratory tract (URT) and lower respiratory tract (LRT) symptoms, i.e. asthma symptoms, and the prevention of more rare complications, such as pneumonia. A diagnosis of asthma is the most common reason for which children should receive influenza vaccination. ${ }^{3}$

Most Western guidelines advise to vaccinate patients with asthma against influenza, ${ }^{4,5}$ although we lack solid evidence from randomised trials for the preventive effect on clinical endpoints, i.e. based on symptoms of asthma. ${ }^{6}$ When advocating a preventive activity, like influenza vaccination in children with asthma, a set of fundamental questions has to be answered. For this purpose, I adapted Demicheli's questions with respect to mass vaccination for influenza, ${ }^{7}$ 
which obviously derive from the criteria used for mass screening. ${ }^{8}$

- Is the condition or the disease to be prevented important?

- Do we know enough about the incidence, the natural history and the burden of this disease to reasonably forecast the likely impact of immunization?

- Does the vaccine work? (That is, is it effective in preventing clinical cases of influenza related asthma exacerbations?)

- Did the vaccine work in our study? (That is, was it effective in preventing clinical cases of influenza related asthma exacerbations?)

- Is the vaccine safe and acceptable? (That is, does it have adverse effects in children with asthma and, if so, are they localized or systemic and of short or long duration? Does the vaccine make the best use of resources available compared with doing nothing or other preventive or therapeutic options?

I will reflect on these questions in the light of the evidence that is now available upon completion of our study. Finally I will make suggestions for altering the guidelines and future research to be done.

\section{Is the condition or the disease to be prevented important?}

Influenza is one of the common respiratory tract infections in children ${ }^{9,10}$ and, according to the World Health Organisation, a yearly public health problem in children as well as in the community at large. ${ }^{11}$ Every season, after the virus has appeared and a rise in influenza like illnesses (ILI) has been assessed, influenza centres worldwide provide information on influenza activity and its presumed impact. ${ }^{12}$ Many viruses, however, can be responsible for influenza like illnesses ${ }^{13-15}$ and the true incidence of influenza proper and its associated illness is still unclear.

Because of different subtypes of the virus and its constant antigenic drift, acquired immunity is usually only partial and therefore the population will always to a greater or lesser extent be susceptible. Thus, to gain an accurate view on the overall impact of influenza one obviously should take several seasons into consideration.

Preferably, for influenza, laboratory proof for the presence of influenza virus should coincide with symptomatic disease. ${ }^{16}$ Yet, in reports on the impact of influenza outbreaks these data are often lacking. Instead, isolated serologic incidence rates, rates of influenza like illness ${ }^{9,12,17-20}$ and the occurrence of complications are used as a proxy. ${ }^{21-24}$ In these studies hard confirmation of 'influenza illness' on the individual level is not possible.

Besides, reports on the burden of disease for influenza (e.g. hospitalisations) are 
often not related to a properly described population at risk. Nevertheless, the clinical, societal and economic impact of non-pandemic influenza seems to be taken for granted and there is hardly any discussion on these basic assumptions.

Children with asthma are reported to be at a higher risk for complications than adults, although no mortality was reported..$^{21-23,25}$ Since these studies were retrospective in design or the population at risk was not well-defined, assumptions on complications of influenza infections in asthmatics are based on indirect evidence. Therefore the information reported in these studies is mostly presented in general terms like "excess health care use" in influenza seasons, regarding for instance hospitalisations or prescriptions for asthma.

In children with asthma, influenza may cause upper respiratory tract infections that often precede exacerbations. Furthermore it is the only respiratory disease for which vaccines are widely available.

However, because far more asthma exacerbations and complications of asthma in children are caused by other viruses, mostly rhinoviruses, the relative impact of influenza on disease in asthmatic children is limited. ${ }^{26,27}$

I conclude that, although the importance of influenza in asthmatic children is frequently stressed, one can question the reliability of the hitherto reported evidence for that belief. Apart from that, the believed importance of influenza obviously relies on the history of pandemics and fear of a new pandemic. ${ }^{28}$

Do we know enough about the incidence, the natural history and the burden of this disease to reasonably forecast the likely impact of immunization?

To gain overview of the available hard evidence for the incidence and the burden of disease due to influenza in children we performed a systematic literature review.

\section{Incidence of influenza and related illness}

Although incidences in specific seasons can peak up to $46 \%$, we found, looking at studies which measured the occurrence of influenza and its related illness over a prolonged time period, the average seasonal incidence of influenza A and $\mathrm{B}$ to be $4.6 \%$ in children $0-19$ years and $9.5 \%$ in children $<5$ years. ${ }^{19}{ }^{29}$ In most of the studies, symptoms that triggered laboratory measurements as well as symptoms assessed in the course of episodes usually were characterised as mild. Convalescence was reported to be rapid ${ }^{30}$ or within a school absence of two days, ${ }^{31}$ whereas the duration of the illness was reported to be between three ${ }^{32}$ 
and 10-13 days. ${ }^{19}$ Mortality as an outcome of influenza illness in children was not found in these studies although case reports sometimes link cases of death in children to influenza infection. ${ }^{33}$ Hospitalisation rates for influenza widely differ in the long term studies included and range from 29 per 100000 children $<16$ years of age $e^{34}$ to 230 per 100,000 children $<5$ years of age. ${ }^{29}$

\section{Incidence of respiratory symptoms due to influenza in children with asthma}

We found only two studies that assessed the incidence of influenza related respiratory illness in asthmatic children while confirming the presence of influenza by culture. This 'hard' incidence was found to be $11.5 \%$ for both influenza A and B in 48 unvaccinated children (aged 2-14 years) under surveillance of an asthma clinic in Japan. ${ }^{35}$ Three children $(6 \%)$ were hospitalised for pneumonia. In another, community based, study $18 \%$ of schoolchildren (aged 9-11 years) had influenza related asthma exacerbations but no serious complications occurred. ${ }^{26}$ Asthma exacerbations as well as episodes of upper respiratory tract symptoms lasted about 7 days and did not differ between viruses detected. In the placebo arm of our trial in asthmatic children the incidence of laboratory confirmed influenza-related asthma exacerbations was found to be $5 \%$, again no serious complications occurred. ${ }^{36}$ Influenza related upper respiratory tract episodes lasted 8 days whereas influenza related asthma exacerbations lasted 11 days.

In conclusion, the incidence of influenza related asthma exacerbations in children and its complications have not been extensively investigated. Incidences for children with asthma as reported here were between 5-18\%. Although one small study, with children under the surveillance of an asthma clinic, found a hospitalisation rate of $6 \%$, no complications were found in the above mentioned community based study on asthmatic children nor in our study that recruited patients in general practice. Regarding the long term overall incidence for influenza related illness in children of $4.6 \%$ ( $0-19$ years) and $9.5 \%$ ( $0-5$ years) and the mild clinical picture of the disease in healthy and asthmatic children one can question the likely impact of immunisation in asthmatic children.

\section{Does the vaccine work?}

Is influenza vaccine effective in preventing clinical cases of influenza related asthma exacerbations? A systematic review of randomised trials of the effects of influenza vaccine in healthy adults showed that inactivated parenteral vaccines indeed had an efficacy of $70 \%$ (95\% confidence interval [CI] $56 \%$ to $80 \%$ ) in 
reducing serologically confirmed cases of influenza. But when using symptom based outcomes, i.e. clinical cases of influenza, the vaccine had only an effectiveness of $25 \%$ (95\% CI $13 \%$ to $35 \%) .{ }^{37}$ These figures on efficacy were recently confirmed in another meta-analysis. ${ }^{38} \mathrm{~A}$ systematic review of randomised trials in asthmatics, children as well as adults, asserted that uncertainty remains about the degree of protection vaccination affords against influenza related asthma exacerbations. ${ }^{6}$ Recapitulating, the vaccine works but the degree of protection against clinical outcomes is meagre for healthy subjects and unknown in asthmatics.

\section{Did the vaccine work in our study?}

\section{Clinical cases of influenza in asthmatic children}

When designing the study we firstly came across the problem that there is no universal definition of an asthma exacerbation, which in my opinion is the most obvious symptom-based complication of influenza in asthma patients. In the available literature different parameters are used, e.g. the prescription of antibiotics or prednisone, visit to a physician for respiratory complaints, hospitalisation and spirometric data. Secondly, URT and general symptoms of influenza infection often precede LRT symptoms typical for an asthma exacerbation. Thus to relate infection to an asthma exacerbation not only lower, but also upper respiratory tract symptoms should provoke the sampling of influenza virus. Thirdly, for the detection of influenza a symptom-based threshold should be set to identify clinically relevant episodes, preventing unnecessary inconvenience of participants and taking into account the available resources, including research personnel. After studying the literature, we found one method that met these three conditions and was used before by Johnston. ${ }^{26}$ In short, an asthma exacerbation was defined as a period of two ore more days with LRT symptoms above the median for that child. For URT as well as LRT symptoms a threshold that triggered culturing influenza was defined. A simple diary with a symptom score list was used for participants to be filled in daily and provided all the necessary data.

Besides respiratory symptoms per se as a clinical relevant outcome of asthma we used a health related questionnaire, which measures changes in quality of life because of asthmatic symptoms on a physical, emotional, and social level, as an endpoint. ${ }^{39,40}$ For this reason the Dutch version of the 23-item Pediatric Asthma Quality of Life Questionnaire (PAQLQ) as designed by Juniper was validated. 


\section{Acquired immunity}

In designing this study on the effectiveness of influenza vaccination in general practice we did not exclude children that acquired immunity by vaccination or infection in previous seasons to mimic the preventive effect of influenza as applied routinely in general practice.

\section{Assumptions}

Several assumptions were made to determine sample size. We wanted to be able to detect a $50 \%$ reduction in the number of asthma exacerbations caused by influenza virus with $\alpha=0.05$ and $\beta=0.2$ (two-sided test). Reported infection rates, mainly based on serological data, have usually been in the range of $20-40 \% .{ }^{18,19}$ We assumed a $30 \%$ incidence and that $50 \%$ of infected children would react with an exacerbation. Thus we aimed at a total number of 600 children for whom complete data would be available, i.e. 300 children per season. This would allow us to show $50 \%$ reduction when $15 \%$ of the children in the placebo group would show influenza-related exacerbations. In the first season, we obtained data from 297 children. However, only six influenza positive throat swabs in the placebo group were found, which is much less than we expected (22). Because of this we seriously considered to stop the study. After careful consideration of various scenarios we decided to continue and make an effort to include more participants during the second season. We aimed at recruiting as many children as possible with the available personnel, and ended up with exactly 400 children, giving a total of 697 children. Because the number of dropouts was surprisingly low, altogether 688 children completed the study.

We investigated two influenza seasons 1999-2000 and 2000-2001, in which H3N2, H1N1 and B subtypes occurred and ended up with 42 influenza related asthma exacerbations, 24 in the placebo group and 18 in the vaccine group, a difference of $33 \%$ favouring placebo (31\% after adjustment for confounders; $95 \%$ confidence interval, $-34 \%$ to $161 \%$ ). Because the incidence of $5 \%$ influenza related asthma exacerbations in the placebo group is much lower than the presumed $15 \%$, questions on power calculations seem inevitable. Though, the issue of power calculation has been raised and debated before, ${ }^{41,42}$ power is not an issue anymore after a study has completed. I quote Altman: "There is [.....] little merit in calculating the statistical power once the results of the trial are known; the power is then appropriately indicated by confidence intervals" ${ }^{43}$ 
We did not aim to study effectiveness for different influenza subtypes present in the vaccine. However, we used a trivalent composition of influenza A (H1N1 and H3N2) and influenza B strains and there may be differences in their protective effectiveness. Several other factors can influence clinical effectiveness such as the phylogenetic distance between the wild virus and the strains in the vaccine, acquired immunity, different incidences and difference in virulence between seasonal occurring subtypes. I am of the opinion that asthmatic children are vaccinated to prevent overall influenza infection and influenza related illness regardless of these factors and think that effectiveness of the vaccine should be measured accordingly. Moreover, in my opinion clinical effectiveness of influenza vaccination should be measured over several seasons to value its overall effectiveness.

\section{Results}

In our randomised trial no effect on the number, duration and severity of influenza related asthma exacerbations was found. Nonetheless an effect on the duration of all asthma exacerbations, irrespective of cause, of 0.8 days as well as discrete effects on health related quality of life in influenza related weeks of illness favouring the vaccine group was found. However, in influenza positive weeks of illness no differences were found between the vaccine group and the placebo group for mean URT or LRT symptoms or spirometry values. Regarding all weeks of illness, irrespective of their cause, no differences were found for mean URT or LRT symptoms or for spirometric parameters. For respiratory symptoms throughout the seasons, influenza vaccination did not reduce URT and LRT symptoms in asthmatic children.

Our conclusion is that on the primary outcome measure, the number of influenza related asthma exacerbations, the $95 \%$ confidence interval of the results from our study excludes a protective effectiveness of influenza vaccination of $35 \%$ or more. Except for a discrete difference for quality of life in influenza positive weeks no other benefits of vaccination were found.

Is the vaccine safe and acceptable? (That is, does it have adverse effects in children with asthma and, if so, are they localized or systemic and of short or long duration?) 
Recent studies did not confirm that influenza vaccination exacerbates asthma defined as complications such as hospitalizations and emergency department visits. ${ }^{44,45}$

In our study we considered local and systemic symptoms, including URT and LRT symptoms, in the first week after influenza vaccination, as adverse effects. Except for one LRT symptom (frequency of cough at daytime) favouring placebo in the first season, we did not find an indication that influenza vaccination provokes asthma exacerbations.

It is clear that safety and tolerability of influenza vaccination in asthmatics are well established by previous research. Our findings using respiratory and other symptoms strongly support the presumed safety. Influenza vaccination can thus be given safely to children with asthma.

Does the vaccine make the best use of resources available compared with doing nothing or other preventive options?

Role of influenza incidence and clinical effectiveness of parenteral influenza vaccine

When determining cost-effectiveness of influenza vaccination several seasons should be considered and included in a cost-effectiveness analysis. However, an overall incidence of influenza related illness between $4.6-9.5 \%$ as found before or $5 \%$ as found in the placebo arm of our study is a difficult starting point. Using this incidence, regardless of clinical relevance and assuming protective effectiveness of vaccination to be $100 \%, 22$ children (0-19 years) 11 children (0-5 years), respectively 20 children (6-18 years) have to be vaccinated in order to prevent influenza related illness in one child. Because the effectiveness of influenza vaccination is lower than $100 \%$ and clinical relevance has to be taken into account, the numbers needed to treat will be higher than calculated here. For instance, in healthy subjects, a clinical effectiveness of the vaccine of just $25 \%$ was found. ${ }^{37}$ When extrapolating, this quadruples the above mentioned numbers needed to treat.

In asthmatics there is no evidence about the degree of protection vaccination provides against influenza related asthma exacerbations. ${ }^{6}$ In our own study, taking the most favourable boundary of the $95 \% \mathrm{CI}$, effectiveness will not be higher than $35 \%$. When assuming a protection rate of $35 \%$, vaccinating 57 children with asthma could prevent only one influenza related asthma exacerbation. 


\section{Other preventive options}

\section{Intranasal vaccines}

In the past years intranasal influenza cold adapted live attenuated vaccines have been developed and tested. Besides the less invasive route of administration, the triggering of the mucosal Ig-A defence system may proof to be a potential benefit. However, serologically as well as clinically, intranasal vaccines have been reported to be less effective than parenterally administered vaccines. ${ }^{37}$

Although intranasal vaccines are generally well tolerated in children and adolescents with asthma no evidence in randomised trials was found for its clinical effectiveness in asthmatics. ${ }^{6}$

\section{Antiviral agents}

Apart from influenza vaccination as preventive treatment for influenza there are antiviral agents that can be used for this purpose.

Amantadine and rimantadine are effective in the treatment and prophylaxis of influenza $\mathrm{A}$, but these drugs are not widely used due to a lack of knowledge of their potential value and concerns about possible adverse effects. ${ }^{46}$

The more recently developed neuraminidase inhibitors zanamivir and oseltamivir are safe and were clinically effective in healthy children with a clinical or laboratory diagnosis of influenza A and B. However, efficacy in 'at risk' children, such as asthma, remains to be proven and its role in the prevention of influenza related illness in asthmatic children is currently not established. ${ }^{47}$

Regarding cost-effectiveness, the balance for antivirals in comparison with vaccination is rather unfavourable. ${ }^{48}$

Inevitably one must conclude that for children with asthma cost-effectiveness for vaccination will be difficult to attain. Other preventive options, which could be used for children with asthma, lack the necessary evidence on clinical endpoints. Furthermore for some of the mentioned alternative options there are doubts about cost-effectiveness.

\section{Conclusion and options for future research}

Summarizing, I conclude that, given the available information on the effectiveness of airway medication; the low overall incidence of influenza; the absence of direct evidence for serious complications of influenza infection in asthmatic children; 
the absence of evidence for the clinical effectiveness of influenza vaccination in asthmatic children; the absence of adverse effects of influenza vaccination and the doubts about cost-effectiveness of this preventive intervention in asthmatic children, guidelines on influenza vaccination should be revised and, despite the safety of vaccination, should reconsider the advice to vaccinate children with mild to moderate asthma.

Future research should first of all focus on long term observational research, spanning more seasons, to determine the real impact of influenza in children with and without asthma. Whereas sentinel stations, in cooperation with national influenza centers, nowadays provide information on the number of influenza like illnesses per number of physicians consultations or at a population level, they could deliver information based on culture confirmed illness and the burden of disease due to influenza in a well defined population at risk. Secondly, experiments in which populations in certain regions, covered by sentinel stations, are asked to participate in vaccination trials, could measure the effect of influenza vaccination in the different age or disease categories, including asthma, for which vaccination is advocated but for which insufficient evidence for its effectiveness is currently available. In this way, the update of recommendations can be guided by medicine-based evidence ${ }^{49}$ which in turn will improve the effectiveness of recommendations. ${ }^{50}$

\section{References}

1 Szefler SJ. The natural history of asthma and early intervention. J Allergy Clin Immunol 2002; 109: S549-553.

2 Williams SG, Schmidt DK, Redd SC, Storms W. Key clinical activities for quality asthma care. Recommendations of the National Asthma Education and Prevention Program. MMWR Recomm Rep 2003; 52: 1-8.

3 Erhart LM, Rangel MC, Lu PJ, Singleton JA. Prevalence and characteristics of children at increased risk for complications from influenza, United States, 2000. J Pediatr 2004; 144: 191-195.

4 Nicholson KG, Snacken R, Palache AM. Influenza immunization policies in Europe and the United States. Vaccine 1995; 13: 365-369.

5 van Essen GA, Palache AM, Forleo E, Fedson DS. Influenza vaccination in 2000: recommendations and vaccine use in 50 developed and rapidly developing countries. Vaccine 2003; 21: 1780-1785.

6 Cates CJ, Jefferson TO, Bara AI, Rowe BH. Vaccines for preventing influenza in people with asthma. Cochrane Database Syst Rev 2004: CD000364. 
7 Demicheli V. Mass influenza vaccination in Ontario: is it worthwhile? CMAJ 2001; 164: 38-39.

8 Wilson JM, Jungner G. Principles and practice of screening for disease. Public Health Papers. Geneva: WHO, 1968.

9 Monto AS, Kioumehr F. The Tecumseh Study of Respiratory Illness. IX. Occurence of influenza in the community, 1966-1971. Am J Epidemiol 1975; 102: 553-563.

10 Freymuth F, Vabret A, Gouarin S, et al. Epidemiology of respiratory virus infections. Allerg Immunol (Paris) 2001; 33: 66-69.

11 Influenza. WHO. Fact sheet $\mathrm{N}^{\circ}$ 211, Revised March 2003. Available at: http://www.who.int/mediacentre/factsheets/2003/fs211/en/.

12 Update: influenza activity-United States and worldwide, 2003-04 season, and composition of the 2004-05 influenza vaccine. MMWR Morb Mortal Wkly Rep 2004; 53: 547-552.

13 Wallace LA, Collins TC, Douglas JD, et al. Virological surveillance of influenza-like illness in the community using PCR and serology. J Clin Virol 2004; 31: 40-45.

14 Iwane MK, Edwards KM, Szilagyi PG, et al. Population-based surveillance for hospitalizations associated with respiratory syncytial virus, influenza virus, and parainfluenza viruses among young children. Pediatrics 2004; 113: 1758-1764.

15 Freymuth F, Vabret A, Gouarin S, et al. [Epidemiology and diagnosis of respiratory syncytial virus in adults] Epidemiologie et diagnostic des infections a virus respiratoire syncytial de l'adulte. Rev Mal Respir 2004; 21: 35-42.

16 Monto AS. Invited commentary: Use of selective viral cultures to adjust nonvirologic endpoints in studies of influenza vaccine efficacy. Am J Epidemiol 2003; 158: 312-315.

17 Foy HM, Cooney MK, Allan I. Longitudinal studies of types A and B influenza among Seattle schoolchildren and families, 1968-74. J Infect Dis 1976; 134: 362-369.

18 Fox JP, Hall CE, Cooney MK, Foy HM. Influenzavirus infections in Seattle families, 1975-1979. I. Study design, methods and the occurrence of infections by time and age. Am J Epidemiol 1982; 116: 212-227.

19 Monto AS, Koopman JS, Longini IM, Jr. Tecumseh study of illness. XIII. Influenza infection and disease, 1976-1981. Am J Epidemiol 1985; 121: 811-822.

20 Tokugawa K, Ueda K, Sakoh M, et al. Seroepidemiologic study on influenza A (H1N1) virus infection among school children after an "antigenic shift" from A $(\mathrm{H} 3 \mathrm{~N} 2)$ to a $(\mathrm{H} 1 \mathrm{~N} 1)$ in Kukuoka of southern Japan in 1978. Pediatr Infect Dis J 1987; 6: 761-762.

21 Izurieta HS, Thompson WW, Kramarz P, et al. Influenza and the rates of hospitalization for respiratory disease among infants and young children. N Engl J Med 2000; 342: 232-239. 
22 Neuzil KM, Mellen BG, Wright PF, et al. The effect of influenza on hospitalizations, outpatient visits, and courses of antibiotics in children. N Engl J Med 2000; 342: 225-231.

23 Meier CR, Napalkov PN, Wegmuller Y, et al. Population-based study on incidence, risk factors, clinical complications and drug utilisation associated with influenza in the United Kingdom. Eur J Clin Microbiol Infect Dis 2000; 19: 834-842.

24 Kim MR, Lee HR, Lee GM. Epidemiology of acute viral respiratory tract infections in Korean children. J Infect 2000; 41:152-158.

25 Weigl JA, Puppe W, Schmitt HJ. The incidence of influenza-associated hospitalizations in children in Germany. Epidemiol Infect 2002; 129: 525-533.

26 Johnston SL, Pattemore PK, Sanderson G, et al. Community study of role of viral infections in exacerbations of asthma in 9-11 year old children. BMJ 1995; 310: 1225-1229.

27 Hayden FG. Rhinovirus and the lower respiratory tract. Rev Med Virol 2004; 14:17-31.

28 Cox NJ, Tamblyn SE, Tam T. Influenza pandemic planning. Vaccine 2003; 21: 1801-1803.

29 Neuzil KM, Zhu Y, Griffin MR, et al. Burden of interpandemic influenza in children younger than 5 years: a 25 -year prospective study. J Infect Dis 2002; 185: 147-152.

30 Moffet HL, Cramblett HG, Middleton Jr. GK, et al. Outbreak of influenza B in a children's home. JAMA 1962; 182: 834-838.

31 Pereira MS, Andrews BE, Gardner SD. A study on the virus aetiology of mild respiratory infections in the primary school child. J Hyg (Lond) 1967; 65: 475-483.

32 Sanders DY, Carroll NB, Jeffreys LU, Vick SS. Outbreak of influenza A2 (Hong Kong strain) in a children's home. South Med J 1970; 63: 414-416.

33 Update: influenza-associated deaths reported among children aged $<18$ yearsUnited States, 2003-04 influenza season. MMWR Morb Mortal Wkly Rep 2004; 52: 1286-1288.

34 Martin AJ, Gardner PS, McQuillin J. Epidemiology of respiratory viral infection among paediatric inpatients over a six-year period in north-east England. Lancet 1978; 2: 1035-1038.

35 Sugaya N, Nerome K, Ishida M, et al. Efficacy of inactivated vaccine in preventing antigenically drifted influenza type A and well-matched type B. JAMA 1994; 272: 1122-1126.

36 Bueving HJ, Bernsen RM, De Jongste JC, et al. Influenza vaccination in children with asthma: randomized double-blind placebo-controlled trial. Am J Respir Crit Care Med 2004; 169: 488-493. 
37 Demicheli V, Rivetti D, Deeks J, Jefferson T. Vaccines for preventing influenza in healthy adults. Cochrane Database Syst Rev 2004; 3: CD001269.

38 Villari P, Manzoli L, Boccia A. Methodological quality of studies and patient age as major sources of variation in efficacy estimates of influenza vaccination in healthy adults: a meta-analysis. Vaccine 2004; 22: 3475-3486.

39 Juniper EF, Guyatt GH, Feeny DH, et al. Measuring quality of life in children with asthma. Qual Life Res 1996; 5: 35-46.

40 Juniper EF. How important is quality of life in pediatric asthma? Pediatr Pulmonol Suppl 1997; 15: 17-21.

41 Monto AS, Fleming DM. Influenza vaccination in children with asthma: no reason to change current recommendations. Am J Respir Crit Care Med 2004; In Press.

42 Bueving HJ, Thomas S, van der Wouden JC. Influenza vaccination in children with asthma, authors reply. Am J Respir Crit Care Med 2004; In Press.

43 Altman DG, Moher D, Schulz KF. Peer review of statistics in medical research. Reporting power calculations is important. BMJ 2002; 325:491.

44 Kramarz P, DeStefano F, Gargiullo PM, et al. Does influenza vaccination exacerbate asthma? Analysis of a large cohort of children with asthma. Vaccine Safety Datalink Team. Arch Fam Med 2000; 9: 617-623.

45 The American Lung Association Asthma Clinical Centers. The safety of inactivated influenza vaccine in adults and children with asthma. N Engl J Med 2001; 345: 1529-1536.

46 Fleming DM. Managing influenza: amantadine, rimantadine and beyond. Int J Clin Pract 2001; 55: 189-195.

47 Matheson NJ, Symmonds-Abrahams M, Sheikh A, et al. Neuraminidase inhibitors for preventing and treating influenza in children. Cochrane Database Syst Rev 2003: CD002744.

48 Turner D, Wailoo A, Nicholson K, et al. Systematic review and economic decision modelling for the prevention and treatment of influenza A and B. Health Technol Assess 2003; 7: iii-iv, xi-xiii, 1-170.

49 Knottnerus JA, Dinant GJ. Medicine based evidence, a prerequisite for evidence based medicine. BMJ 1997; 315: 1109-1110.

50 Burgers JS, Grol RP, Zaat JO, et al. Characteristics of effective clinical guidelines for general practice. Br J Gen Pract 2003; 53: 15-19. 
Summary 


\section{Summary}

Every year, outbreaks of influenza appear across the world and cause substantial morbidity and mortality in the general population, particularly in persons with underlying conditions including asthma. Because the influenza virus changes constantly, man's acquired immunity is usually only partial and therefore the population will always to a greater or lesser extent be susceptible.

In asthmatics, influenza causes upper respiratory tract infections that frequently trigger exacerbations. Large population-based studies have estimated the morbidity and the risk of developing clinical complications in people with asthma. During influenza periods, hospitalisation, drug prescriptions and visits to physicians increase, and asthma exacerbations and pneumonia have been reported as the most common complications. Children with asthma are at a higher risk for complications than adults. Reasons to vaccinate asthmatics are the prevention of influenza-related illness and complications, including asthma exacerbations and death. However, the protective effect of influenza vaccination in asthmatic patients is still disputed. So far no unequivocal beneficial effect of influenza vaccination in asthmatics was found in observational and experimental studies in the sense of reduction of asthma exacerbations and of other complications.

Although opinions on the clinical effectiveness of influenza vaccination in asthmatic patients are currently based on consensus and indirect evidence, the guidelines of most Western countries advise to vaccinate patients with asthma. As a result, in asthma care, influenza vaccination is considered to be a cornerstone for quality of care.

Despite these recommendations only a minority of asthma patients is vaccinated worldwide. Reasons for this are fear among patients that vaccination could cause influenza, and doubts about benefits and effectiveness of influenza vaccination amongst physicians and patients.

Aim of this thesis is to provide evidence to either support or modify the policy of vaccinating asthmatic patients as is described in most western guidelines. I will focus on children, because in children asthma is the most important reason for influenza vaccination and asthma is the most frequent chronic disease in childhood.

In chapter 2 we report on the available knowledge of the incidence of influenza, the natural course and the burden of disease. Incidence figures are a prerequisite to reliably forecast the impact of preventive measures for influenza and calculate 
the number needed to treat in order to prevent one additional case of influenza. Likewise, incidence figures are also needed to estimate the number of participants for preventive or therapeutic trials.

We conducted a systematic review to estimate the incidence of influenza and concomitant morbidity and mortality in children 0 through 19 years (0-19 years). We searched for observational studies and placebo or non treated arms of experimental studies for information on laboratory proven influenza illness.

From a total of 2758 papers, 356 papers were reviewed on the basis of abstract or title. Sixteen papers were added searching the reference list of these papers. Finally 28 studies met inclusion criteria. They showed a varying incidence of influenza with figures up to $46 \%$. However, when looking at two long term observational studies and averaging seasonal fluctuations, the overall incidence of influenza in children was found to be between 5\% (children aged 0-19 years) and 9.5\% (children aged 0-5 years) per year. Serious morbidity was seldom reported. In the studies selected we found no cases of mortality.

Our conclusion is that, given the average incidence for influenza found, the selflimited character of the disease, the mild associated morbidity and the rare cases of mortality in children, one can question if influenza in children at a population level is a major public health problem. As a result of this outcome we advise that preventive strategies for children should be reconsidered. When investigating preventive strategies for influenza one should be led by the average incidence and include more seasons.

In chapters 3-6 we present various results of our randomised double-blind placebo-controlled trial in 696 children with asthma, aged 6-18 years. Parenteral vaccination with inactivated influenza vaccine or placebo took place approximately November $1^{\text {st }}$, and children were followed until April $1^{\text {st }}$ of the next year. Local and systemic symptoms, possibly as a result of vaccination, and airway symptoms were reported in a diary. Symptoms scored during the first week after vaccination were considered to be adverse effects of the vaccination. When symptom scores reached a predefined level, a pharyngeal swab was taken and spirometry was performed. One week later a quality of life questionnaire was administered. Primary outcome was the number of asthma exacerbations associated with virologically proven influenza infection. Three hundred forty-nine children were assigned placebo, and 347 were assigned vaccine. 
In chapter 3, we address the adverse effects of influenza vaccination, especially on asthma. Because there is a constant debate that influenza vaccination may provoke an asthma exacerbation, a decisive answer to these doubts may affect vaccination rate.

During the first week after vaccination, participants recorded local, influenza like and asthma symptoms as well as use of medication, health care use and absenteeism. As reported in previous studies, vaccine recipients reported redness and stiffness of the arm much more often than placebo recipients. For symptoms of influenza like illness, fever, headache and myalgia showed smaller though significant differences during the first season, as did hoarseness during the second season, all favouring placebo. These differences may be an expression of the difference between strains used in the vaccine during the two seasons or may be a result of a difference between populations studied in the two influenza seasons. Except for cough during the day in the first season, favouring placebo, there were no differences indicating that vaccination exacerbates asthma. We conclude that influenza vaccination does not seem to exacerbate asthma and can be given safely to asthmatic children.

In the literature there is little evidence that influenza vaccination reduces asthma exacerbations. In chapter 4 we report the main results of our randomised doubleblind placebo-controlled trial in asthmatic children regarding the preventive effect of influenza vaccination on clinical illness, notably asthma exacerbations.

Children reported, as described above, airway symptoms in a diary. When symptom scores reached a predefined level, a pharyngeal swab was taken. Primary outcome was the number of asthma exacerbations associated with virologically proven influenza infection. We considered a reduction in asthma exacerbations of at least $50 \%$ as clinically relevant. Three hundred forty-nine children were assigned placebo, and 347 were assigned vaccine. Pharyngeal swabs positive for influenza were related to 42 asthma exacerbations, 24 in the vaccine group and 18 in the placebo group, a difference of $33 \%$ favouring placebo (31\% after adjustment for confounders; $95 \%$ confidence interval, $-34 \%$ to $161 \%$ ). Influenza-related asthma exacerbations were of similar severity in both groups; they lasted 3.1 days shorter in the vaccine group $(95 \%$ confidence interval, -6.2 to -0.002 days, $\mathrm{p}=0.06$ ). We conclude that influenza vaccination did not result in a significant reduction of the number, severity, or duration of asthma exacerbations caused by influenza. We think additional studies, using influenza proven clinical illness 
as an endpoint, are warranted to justify routine influenza vaccination of children with asthma.

Health-related quality of life (physical, social and emotional impairments) should be an important measure in evaluations of the management of childhood asthma. Therefore, in chapter 5, the Pediatric Asthma Quality of Life Questionnaire (PAQLQ), a questionnaire in English to define quality of life in asthmatic children, is validated for the Dutch translation.

We assessed psychometric properties, responsiveness, and longitudinal and crosssectional construct validity of the Dutch PAQLQ version. The study group consisted of 238 children (6-18 years) with asthma, a subset of children from our trial on influenza vaccination, with complete respiratory symptom diaries in the course of one winter season; each child had one (or more) PAQLQ measurement(s) concerning one (or more) week(s) with relatively many symptoms $(n=238)$. Each child also had one PAQLQ measurement concerning another week with relatively few symptoms. The PAQLQ scores of these weeks were compared. Additionally, in a subgroup of the study group that had experienced two or more 'weeks with many symptoms' $(n=101)$, we compared the PAQLQ scores for two different weeks with many symptoms of these children. All Cronbach's $\alpha$ 's of the PAQLQ total score and domains were above 0.70 , except for Activities $(\alpha=0.54)$, indicating that the internal consistency of the questions in the questionnaire is moderate to good. Mean PAQLQ scores were significantly different ( $\mathrm{p}<0.01 ; n=238$ ) between one week with few symptoms and another week with many symptoms. Contrarily, in the subgroup of children with PAQLQ measurements regarding more than a week with many symptoms $(n=101)$, mean PAQLQ scores did not differ significantly ( $\mathrm{p}>0.05$ ) between a week with many symptoms and another week with many symptoms. These results indicate responsiveness of the instrument. Changes in lower respiratory tract symptoms, indicative of asthma severity, correlated better with changes in PAQLQ scores than changes in upper respiratory tract symptoms, which supports the longitudinal and cross-sectional construct validity. The assessed properties of the translation into Dutch were similar to those originally established for the PAQLQ in Canada. This study showed that the Dutch PAQLQ has adequate psychometric properties, excellent responsiveness, and that its longitudinal and cross-sectional construct validity is supported. As this questionnaire has been translated and validated in several languages it is an excellent tool for international and trans-cultural asthma research. 
In chapter 6 we show the effect of influenza vaccination on the well being of asthmatic children.

Using PAQLQ, we measured the effects of influenza vaccination on physical, emotional and social impairments in asthmatic children. Supplementary we assessed whether influenza vaccination has an effect on the corresponding respiratory symptoms and spirometric parameters as well as on all their symptoms throughout the season.

Compared to placebo, vaccination improved health-related quality of life in the weeks of illness related to influenza-positive swabs. However, no effect was found for respiratory symptoms recorded in the diaries during those weeks. Similarly, no differences were found for quality of life in all weeks of illness or for respiratory symptoms throughout the seasons.

Our conclusion is that influenza vaccination has a moderate beneficial effect on quality of life in influenza-positive weeks of illness in children with asthma.

In chapter 7 we reflect on our findings and conclude that, given the available information on the effectiveness of airway medication; the low overall incidence of influenza; the absence of direct evidence for serious complications of influenza infection in asthmatic children; the absence of evidence for the clinical effectiveness of influenza vaccination in asthmatic children; the absence of adverse effects of influenza vaccination and the doubts about cost-effectiveness of this preventive intervention in asthmatic children, guidelines on influenza vaccination should be revised and, despite the safety of vaccination, should reconsider the advice to vaccinate children with mild to moderate asthma.

Future research should first of all focus on long term observational research, spanning more seasons, to determine the real impact of influenza in children with and without asthma. Whereas sentinel stations, in cooperation with national influenza centres, nowadays provide information on the number of influenza like illnesses per number of physicians consultations or at a population level, they could deliver information based on culture confirmed illness and the burden of disease due to influenza in a well defined population at risk. Secondly, experiments in which populations in certain regions, covered by sentinel stations, would be asked to participate in vaccination trials, could measure the effect of influenza vaccination in the different age and disease categories, including asthma, for which vaccination is advocated but for which insufficient evidence for its effectiveness is currently available. In any case, experimental designs should take symptoms of patients on an individual level and symptom based measurements, such as 
PAQLQ, as an outcome. In this way, the updating of recommendations can be guided by medicine-based evidence wich in turn may improve the effectiveness of recommendations. 
Samenvatting 


\section{Samenvatting}

Over de gehele wereld zijn er ieder jaar uitbraken van influenza die substantiële morbiditeit en mortaliteit teweeg brengen onder de bevolking, in het bijzonder bij personen met een onderliggend lijden zoals astma. Omdat het influenzavirus constant verandert is de bescherming die men na een infectie opbouwt slechts gedeeltelijk, hierdoor zal de bevolking altijd in meerdere of mindere mate ontvankelijk zijn voor het influenzavirus.

Een influenza-infectie veroorzaakt bij patiënten met astma een ontsteking van de bovenste luchtwegen die vaak een astma-aanval uitlokt. Er zijn grote studies gedaan waarbij onderzocht is hoeveel ziekte er veroorzaakt wordt door influenza en wat de kans is op klinische complicaties bij patiënten met astma. Het aantal ziekenhuisopnames, medicijnvoorschriften en bezoeken aan een arts stijgt tijdens griepperiodes en als meest voorkomende complicaties treden astmaaanvallen en longontsteking op. Kinderen met astma lopen een groter risico op complicaties dan volwassenen. Patiënten met astma worden gevaccineerd ter voorkoming van door influenza veroorzaakte ziekte en de bijbehorende complicaties, waaronder astma-aanvallen en overlijden. Het beschermende effect van influenzavaccinatie is echter nog steeds onderwerp van discussie. Tot nu toe is in observationele en experimentele studies niet ondubbelzinnig aangetoond dat influenzavaccinatie het aantal astma-aanvallen of andere complicaties van influenza gunstig beïnvloedt.

Hoewel de ideeën over de klinische effectiviteit van influenzavaccinatie bij patiënten met astma op dit moment zijn gebaseerd op consensus en indirect bewijs, wordt in de richtlijnen van de meeste Westerse landen geadviseerd patiënten met astma te vaccineren tegen influenza. Griepvaccinatie wordt dan ook gezien als een hoeksteen van de kwaliteit van de zorg bij patiënten met astma.

Ondanks de genoemde aanbevelingen wordt wereldwijd slechts een minderheid van de astmapatiënten gevaccineerd. Bij patiënten bestaat er angst dat vaccinatie juist influenza veroorzaakt en bij patiënten én artsen blijven er twijfels bestaan over de voordelen en de effectiviteit van influenzavaccinatie.

Dit proefschrift wil bewijs leveren ter ondersteuning of aanpassing van het in de meeste westerse landen gevoerde beleid om patiënten met astma te vaccineren tegen influenza. Ik beperk me daarbij tot kinderen: bij hen is astma de meest voorkomende chronische ziekte en tevens de belangrijkste reden voor griepvaccinatie. 
In hoofdstuk 2 beschrijven we de kennis die op dit moment aanwezig is met betrekking tot de incidentie, het natuurlijke verloop en de ziektelast van influenza.

Incidentiecijfers zijn onontbeerlijk om de gevolgen van preventieve maatregelen tegen influenza te kunnen voorspellen en te berekenen hoeveel mensen gevaccineerd moeten worden om één geval van influenza te voorkomen. Deze cijfers zijn ook een voorwaarde om het aantal benodigde deelnemers voor preventieve of therapeutische trials te kunnen schatten.

We voerden een systematische review uit om te bepalen wat de incidentie van influenza en de daardoor veroorzaakte morbiditeit en mortaliteit is bij kinderen van 0 tot en met 19 jaar (0-19 jaar). Daarbij zochten we naar informatie over, middels laboratoriumonderzoek bewezen, door influenza veroorzaakte ziekte in observationele studies en experimentele studies met een placebo arm of een arm waarin geen behandeling plaatsvond.

Van in totaal 2758 artikelen werden 356 artikelen, op basis van het abstract of de titel, door de beoordelaars besproken. Zestien artikelen werden toegevoegd op basis van de referentielijsten van deze artikelen. Uiteindelijk voldeden 28 artikelen aan de inclusiecriteria.

De incidentiecijfers van influenza varieerden nogal met als hoogste cijfer een incidentie van $46 \%$. Als we echter kijken naar de twee gevonden langjarige observationele studies, bleek de gemiddelde jaarsincidentie van influenza bij kinderen te liggen tussen 5\% (0-19 jaar) en 9.5\% (0-5 jaar). Ernstige morbiditeit werd zelden beschreven en in de geselecteerde studies werd mortaliteit niet genoemd.

Als we kijken naar de gemiddelde incidentie van influenza, het zichzelf beperkende karakter van de ziekte, de milde bijkomende morbiditeit en de zeldzaamheid van mortaliteit bij kinderen, is het de vraag of influenza bij kinderen op bevolkingsniveau een groot maatschappelijk gezondheidsprobleem is. Op basis van onze uitkomsten is ons advies de huidige preventieve maatregelen te heroverwegen. Daarnaast vinden we dat bij onderzoek van preventieve strategieën voor influenza men zich moet laten leiden door de gemiddelde incidentie én meerdere seizoenen in beschouwing moet nemen.

In hoofdstuk 3-6 presenteren we de resultaten van ons gerandomiseerde dubbelblinde placebogecontroleerde onderzoek bij 696 kinderen met astma in de leeftijdsgroep van 6 tot en met 18 jaar. Rondom 1 november ontvingen de kinderen een injectie met geïnactiveerd influenzavaccin of placebo, de kinderen 
werden daarna gevolgd tot 1 april van het daaropvolgende jaar. $\mathrm{Zij}$ noteerden locale en algemene klachten ten gevolge van de vaccinatie en luchtwegklachten in een dagboekje. De genoteerde klachten in de eerste week beschouwden we als bijwerking van de vaccinatie. Als, na de eerste week, de gescoorde luchtwegklachten een van tevoren afgesproken grens bereikten, werd een keelwat afgenomen en vond een longfunctiemeting plaats. Een week later werd een kwaliteit van levenvragenlijst afgenomen. Van de deelnemende kinderen ontvingen 349 het placebovaccin en 347 het influenzavaccin.

In hoofdstuk 3 onderzochten we de bijwerkingen van griepvaccinatie vooral met betrekking tot de gevolgen voor het astma. Omdat er al lang discussie is over de vraag of influenzavaccinatie een astma-aanval kan uitlokken is een duidelijk antwoord op deze vraag van belang. Dit kan belangrijke gevolgen hebben voor de vaccinatiegraad.

Gedurende de eerste week na de vaccinatie noteerden de deelnemers aan de trial klachten op de plaats van de prik, griepachtige klachten en astmaklachten en tevens medicatiegebruik, gezondheidszorggebruik en afwezigheid. Conform eerdere studies rapporteerden de deelnemers die het echte vaccin ontvingen veel vaker roodheid en een stijve arm dan zij die met placebo gevaccineerd waren. Wat betreft griepachtige symptomen waren er kleinere maar wel significante verschillen, ten voordele van de placebogevaccineerden, voor koorts, hoofdpijn en spierpijn in het eerste seizoen en heesheid in het tweede seizoen. Het verschil tussen de seizoenen zou te maken kunnen hebben met het verschil tussen de in het vaccin gebruikte stammen gedurende de twee seizoenen, maar kan ook een gevolg zijn van een verschil tussen de in de twee seizoenen deelnemende kinderen. Behalve een verschil voor hoesten overdag in het eerste seizoen ten voordele van de placebogevaccineerden waren er geen aanwijzingen dat vaccinatie astma-aanvallen uitlokte. Onze conclusie is daarom dat griepvaccinatie geen astma-aanvallen lijkt uit te lokken en veilig toegediend kan worden aan kinderen met astma.

In de wetenschappelijke literatuur is er weinig bewijs dat griepvaccinatie astmaaanvallen voorkómt. In hoofdstuk 4 doen we verslag van de belangrijkste resultaten van ons gerandomiseerde dubbelblinde placebogecontroleerde onderzoek bij kinderen met astma naar het effect van influenzavaccinatie, waarbij we in het bijzonder naar astma-aanvallen keken. 
De deelnemende kinderen noteerden, zoals hiervoor beschreven, luchtwegklachten in een dagboekje. Als de gescoorde luchtwegklachten een van tevoren afgesproken grens bereikten, werd een keelwat afgenomen. Onze primaire uitkomstmaat was het aantal astma-aanvallen dat in verband gebracht kon worden met een virologisch bewezen influenza-infectie. We beschouwden een reductie van tenminste $50 \%$ van het aantal astma-aanvallen als klinisch relevant. Van de deelnemende kinderen ontvingen 349 het placebovaccin en 347 het influenzavaccin. Van de gerapporteerde astma-aanvallen waren er 42 gerelateerd aan een influenzapositieve keelwat, 24 in de gevaccineerde groep en 18 in de placebogroep. Een verschil van $33 \%$ ten voordele van de placebogroep (31\% na correctie voor 'confounders'; $95 \%$ betrouwbaarheidsinterval $-34 \%$ tot $161 \%$ ). Influenzagerelateerde astmaaanvallen waren even ernstig in beide groepen; ze duurden 3,1 dag korter in de vaccingroep ( $95 \%$ betrouwbaarheidsinterval, $-6,2$ tot $-0,002 \mathrm{dag}, \mathrm{p}=0,06)$. Onze conclusie is dat influenzavaccinatie niet resulteerde in een significante vermindering van het aantal, de ernst en de duur van influenzagerelateerde astma-aanvallen. We zijn van mening dat aanvullende studies, waarbij ziekte in combinatie met bewijs voor influenza als eindpunt gebruikt wordt, noodzakelijk zijn om het jaarlijks vaccineren van kinderen met astma te rechtvaardigen.

Gezondheidsgerelateerde kwaliteit van leven (op lichamelijk, sociaal en emotioneel vlak) zou een belangrijke maat moeten zijn bij de evaluatie van de bewaking en controle van patiënten met astma.

In hoofdstuk 5 wordt de validering beschreven van de Nederlandse vertaling van de Engelstalige "Pediatric Asthma Quality of Life Questionnaire” (PAQLQ).

We stelden de psychometrische eigenschappen, de responsiviteit, en de longitudinale en cross-sectionele constructvaliditeit van de Nederlandstalige PAQLQ vast. De bestudeerde groep bestond uit 238 kinderen (6-18 jaar) met astma, bestaande uit kinderen uit de trial naar het effect van griepvaccinatie, die een compleet dagboek met luchtwegsymptomen hadden ingevuld. Ieder kind onderging één (of meer) PAQLQ-meting(en) betreffende één of meer weken met betrekkelijk veel symptomen $(n=238)$. Ieder kind beschikte ook over een PAQLQ-meting betreffende een week met betrekkelijk weinig symptomen. De PAQLQ-scores van deze weken werden vergeleken. Daarnaast vergeleken we een subgroep van kinderen met twee of meer weken met veel symptomen $(n=101)$, we vergeleken de PAQLQ-scores van twee verschillende weken met veel symptomen van deze kinderen. De Cronbachs $\alpha$ 's van de totale score en de domeinscores waren allen groter dan 0,70 , behalve voor het domein activiteiten $(\alpha=0,54)$. Dit geeft aan 
dat de interne consistentie van de vragen in de vragenlijst matig tot goed is. De gemiddelde PAQLQ-scores verschilden significant $(\mathrm{p}<0,01 ; n=238)$ tussen een week met weinig en een week met veel symptomen. Daarentegen verschilden in de subgroep van kinderen met PAQLQ-metingen die meer dan één week met veel symptomen hadden $(\mathrm{n}=101)$ de gemiddelde PAQLQ-scores niet significant $(p \geq 0,05)$ tussen de ene en de andere week met veel symptomen. Deze resultaten zijn een aanwijzing voor de responsiviteit van de vragenlijst. Veranderingen in de scores van lagere luchtwegsymptomen, een aanwijzing voor de ernst van het astma, kwamen beter overeen met veranderingen in de PAQLQ-scores dan veranderingen in de scores van hogere luchtwegsymptomen. Dit ondersteunt de longitudinale en cross-sectionele constructvaliditeit van de PAQLQ. De vastgestelde eigenschappen van de Nederlandse vertaling van de PAQLQ waren gelijk aan de geconstateerde eigenschappen van de oorspronkelijke Canadese versie. Deze studie laat zien dat de Nederlandstalige PAQLQ adequate psychometrische eigenschappen heeft, een uitstekende responsiviteit bezit, en tevens wordt de longitudinale en crosssectionele constructvaliditeit onderbouwd. Omdat deze vragenlijst inmiddels in verschillende talen is vertaald en gevalideerd, is het een uitstekend instrument voor internationaal en transcultureel astma-onderzoek.

In hoofdstuk 6 laten we het effect van griepvaccinatie op het welbevinden van kinderen met astma zien.

Gebruik makend van de PAQLQ maten we het effect van griepvaccinatie op het fysieke, emotionele en sociale vlak bij astmatische kinderen. Daarnaast stelden we vast of griepvaccinatie een effect had op de met de PAQLQ-metingen corresponderende luchtwegklachten en spirometrische parameters en tevens op ál hun symptomen gedurende het seizoen.

Vergeleken met placebo verbeterde vaccinatie de gezondheidgerelateerde kwaliteit van leven in weken waarin de kinderen klachten hadden én de keelwat positief bleek voor influenza. Er werd echter geen effect gevonden wanneer we keken naar de luchtwegsymptomen die in die weken in het dagboek gescoord werden. Evenzeer vonden we geen verschil in kwaliteit van leven wanneer we alle weken met ziekte of luchtwegklachten over de seizoenen heen vergeleken.

Onze conclusie luidt dat influenzavaccinatie een gematigd positief effect heeft op de kwaliteit van leven in influenza-positieve weken bij kinderen met astma.

In hoofdstuk 7 beschouwen we onze bevindingen en komen tot de slotsom dat, gegeven de beschikbare informatie met betrekking tot de effectiviteit van 
luchtwegmedicatie; de lage gemiddelde incidentie van influenza; de afwezigheid van direct bewijs voor de klinische effectiviteit van influenzavaccinatie bij kinderen met astma; de afwezigheid van ernstige bijwerkingen van griepvaccinatie en de twijfels over de kosteneffectiviteit van deze preventieve interventie bij astmatische kinderen, de richtlijnen met betrekking tot griepvaccinatie zouden moeten worden herzien en men, ondanks de veiligheid van de vaccinatie, het advies kinderen met matig tot ernstig astma te vaccineren zou moeten heroverwegen.

Toekomstig onderzoek zou zich als eerste moeten richten op lange termijn observationeel onderzoek en meerdere seizoenen moeten omvatten om de werkelijke weerslag van influenza bij kinderen met en zonder astma vast te stellen. Terwijl peilstations nu, in samenwerking met nationale influenzacentra, informatie verschaffen over het aantal griepachtige ziekten per aantal artscontacten of op het niveau van de algehele bevolking, zouden ze ook informatie kunnen leveren gestoeld op door kweek bewezen ziekte ten gevolge van influenza en over de ziektelast van influenza in een goed gedefinieerde populatie 'at risk'.

Ten tweede zouden experimenten het effect kunnen meten van griepvaccinatie in verschillende leeftijds- en ziektegroepen, waaronder astma, waarvoor vaccinatie wordt geadviseerd maar waarvoor onvoldoende bewijs voorhanden is, waarbij de door peilstations gedekte bevolking in een bepaalde regio gevraagd zou kunnen worden mee te doen aan vaccinatieonderzoek. In ieder geval zouden studies zo moeten worden opgezet dat symptomen van patiënten op individueel niveau, en op symptomen gebaseerde metingen, zoals de PAQLQ, als uitkomstmaat worden genomen. Op deze wijze wordt aanpassing van de aanbevelingen geleid door op geneeskunde gestoeld bewijs, hetgeen de doeltreffendheid van de aanbevelingen kan verbeteren. 


\section{Publications and manuscripts related to this thesis}

1. van der Wouden JC, Bueving HJ, Bernsen RM. Influenza vaccine and asthma. J Pediatr 2002; 140: 278-279.

2. van der Wouden JC, Bueving HJ. Comment: safety and efficacy of influenza vaccine in children. Ann Pharmacother 2004; 38: 1323-1324.

3. Bueving HJ, Bernsen RM, De Jongste JC, et al. Influenza vaccination in children with asthma: randomized double-blind placebo-controlled trial. Am J Respir Crit Care Med 2004; 169: 488-493.

4. Bueving HJ, Thomas S, van der Wouden JC. Influenza vaccination in children with asthma, authors reply. Am J Respir Crit Care Med 2004; In Press.

5. Bueving HJ, Bernsen RM, De Jongste JC, et al. Griepvaccinatie bij kinderen met astma: een gerandomiseerd dubbelblind placebo-gecontroleerd onderzoek. Huisarts Wet 2004; 47: 491-497.

6. Bueving HJ, van der Wouden JC, Thomas S. Voorbarige conclusie over effectiviteit griepprik bij kinderen, reply. Huisarts Wet 2004; 47: 666-667.

7. Bueving HJ, Bernsen RM, de Jongste JC, et al. Does influenza vaccination exacerbate asthma in children? Vaccine 2004; 23: 91-96.

8. Bueving $\mathrm{HJ}$, van der Wouden JC, Raat $\mathrm{H}$, et al. Influenza vaccination in asthmatic children: effects on quality of life and symptoms. Eur Respir J 2004; 24: 925-931.

9. Bueving HJ, Thomas S, Wouden JC. Is influenza vaccination in asthma helpful? Curr Opin Allergy Clin Immunol 2005; 5: 65-70.

10. Raat H, Bueving HJ, De Jongste JC, et al. Responsiveness, longitudinal and cross sectional construct validity of the Pediatric Asthma Quality of Life Questionnaire (PAQLQ) in Dutch children with asthma. Qual Life Res 2005; 14: 265-272. 


\section{Persoonlijk dankwoord}

Mijn dank gaat in het bijzonder uit naar:

Hans van der Wouden, co-promotor, die aan de wieg heeft gestaan van dit onderzoek en als een geduldige en onvermoeibare vader geboorte, puberteit en wasdom van alle geschriften heeft begeleid.

Hans, dat moet haast een kwestie van levenservaring met die fases zijn,

Lya Euser, coördinatrice, die op haar eigen gestrenge wijze het veldwerk, uitgevoerd door vele deeltijds aangestelde zusters, en de daaruit voortvloeiende gegevensstroom in goede banen leidde,

Siep Thomas, promotor, die bij elk geschrift wilde weten wat ik nu éigenlijk vertellen wilde,

Frits Bareman, plaatsvervangend hoofd, die mijn taken als hoofd huisartsopleiding regelmatig stijlvol waarnam,

Yvonne Jacobsen, mijn echtgenote, je bent een kanjer,

Mirjam en Naomi, Ruben, Judith, Sarah en Aron, mijn kinderen en kleinkind, die de ruimte die ik nam voor het schrijven thuis zonder pardon inperkten en deze promotie als een uitstekende gelegenheid zagen hun kleedgeld éénmalig op te krikken. 
Vele anderen hebben bijgedragen aan het onderzoek naar influenza en de totstandkoming van dit proefschrift, of hebben mij gesteund,

\title{
mijn oprechte dank gaat uit naar:
}

\author{
Hoofdrolspelers \\ Kinderen met astma en hun ouders \\ Huisartsen en assistentes
}

Regisseurs en bewakers van de rode draad

Prof dr. Siep Thomas, promotor

Dr. Johannes C. (Hans) van der Wouden, co-promotor

\section{Statistica}

Roos Bernsen

Veldwerkers

Coördinatrice

Lya Euser

Zusters

Jannie Blom

Metthilde Bos

Ellen Duijster-Kunst

Gonnie van Eijken

Carine van Egten

Vera Mollers

Toke Mulder-van Kempen

Jeanette Reijerkerk

Caroline Rietveld

Iris Schoenmakers

Mariet op 't Veld-Mulders

Marianne Verspeek

Thea Zweers 
Virologen

Albert Osterhaus

Frank Pistoor

Guus Rimmelzwaan

Data-verwerkers

Roel Verkooyen

Kris Sieradzan

Annelies Kodde

Mede-auteurs

Marjolein Berger

Roos Bernsen

Marjon Grol

Johan de Jongste

Elisabeth Juniper

Albert Osterhaus

Hein Raat

Guus Rimmelzwaan

Maureen Rutten-van Mölken

Lisette van Suijlekom-Smit

Siep Thomas

Hans van der Wouden

Cochrane review on influenza and asthma

Chris Cates

Correctrice Engels

L. Visser-Isles

Werkfront

Frits Bareman

Jeannette Deurloo

Hans van der Wouden

Marjolein Berger

Corine Penning

Sander Koning

Hanneke Otters 
Michiel van der Linden

René Suurland

Alle overige Westzeedijk-bewoners afdeling huisartsgeneeskunde Alle overige Hoboken-bewoners afdeling huisartsgeneeskunde

\author{
Thuisfront \\ Yvonne Jacobsen \\ Mirjam en Naomi \\ Ruben \\ Judith \\ Sarah \\ Aron
}

Ouders

Vader Marten (Max) Bueving †

Moeder Wemeltje (Willie) Bousema

Drukker

Martin Bueving

Subsidiegever

ZonMw

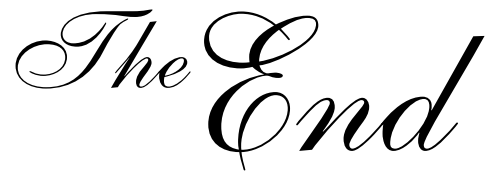

